Pacific Northwest

National Laboratory

Operated by Battelle for the

U.S. Department of Energy

\section{Revised Hydrogeology for the Suprabasalt Aquifer System, 200-West Area and Vicinity, Hanford Site, Washington}

\author{
BA Williams \\ BN Bjornstad \\ R Schalla \\ WD Webber
}

May 2002

Prepared for the U.S. Department of Energy under Contract DE-AC06-76RL01830 


\title{
DISCLAIMER
}

This report was prepared as an account of work sponsored by an agency of the United States Government. Reference herein to any specific commercial product, process, or service by trade name, trademark, manufacturer, or otherwise does not necessarily constitute or imply its endorsement, recommendation, or favoring by the United States Government or any agency thereof, or Battelle Memorial Institute.

\author{
PACIFIC NORTHWEST NATIONAL LABORATORY \\ operated by \\ BATTELLE \\ for the \\ UNITED STATES DEPARTMENT OF ENERGY \\ under Contract DE-AC06-76RL01830
}

$\Delta s$ This document was printed on recycled paper. 


\section{Summary}

The primary objective of this study was to refine the conceptual groundwater flow model for the 200-West Area and vicinity. This is the second of two reports that combine to cover the Central Plateau, an area that holds the largest inventory of radionuclide and chemical wastes on the Hanford Site. This inventory is located in underground storage tanks, the vadose zone, and the saturated zone. Within the saturated zone, groundwater contaminant plumes, originating from past-practice activities at facilities within this area, are migrating toward the Columbia River where they may be accessible to the public.

This study supports the Hanford Groundwater/Vadose Integration Project objectives to better understand the impacts of groundwater contamination and potential risk to the public via the groundwater flow pathway.

The primary components of the conceptual groundwater flow model are 1) the static elements of the subsurface that form the hydrogeologic framework and 2) the groundwater that moves through this framework in response to stresses within the aquifer. The previous conceptual model was used as the baseline and was updated using new data and by re-evaluating existing data and reports from previous investigations to include essentially all the suprabasalt hydrogeology and associated groundwater flow information beneath the 200-West Area and vicinity. Current groundwater monitoring and cleanup efforts are focused on the upper portion of the unconfined aquifer within the suprabasalt aquifer system. This report evaluates more completely the entire vertical sequence of the suprabasalt sediments including description of the aquifer systems separated by the Ringold Unit 8. Contaminants have been detected in groundwater at various depths within these two systems, but our current understanding of groundwater flow and contaminant transport in the lower portion of these aquifers is limited.

Based on this study, hydrogeologic mapping indicates that the confining (Aquitard) Ringold Unit 8 rises to the east and is located at or near the water table of the upper unconfined aquifer in the northeast portion of the study area, downgradient from 200-West Area contaminant source areas.

Groundwater and contaminants from the northern portion of the 200-West Area will likely flow northeast into more permeable Hanford formation sediments within an erosional paleochannel.

Continued water-level decline will expose more of Ringold Unit 8 and the Columbia River basalt above the water table northeast of 200-West Area near Gable Gap, restricting groundwater and contaminant flow in that direction and possibly diverting contaminant plumes to the southeast across 200-East Area.

The uppermost-unconfined aquifer averages about $40 \mathrm{~m}(131 \mathrm{ft})$ thick beneath most of the 200-West Area. Characterization of contaminants located in the lower three-fourths of the unconfined aquifer and the confined Ringold aquifer beneath the 200 -West Area and vicinity is very limited. The assessment of these contaminants may be important in developing successful cleanup or site closure options for Hanford's groundwater. 


\section{Acknowledgments}

The authors extend their appreciation to reviewers Steve Reidel, George Last, Stuart Luttrell, and many others whose comments and suggestions helped us improve this report. Text editing was performed by Georganne O'Connor and Launa Morasch. Lila Andor and Kathy Neiderhiser performed the text processing to produce a quality document in a format that works in paper and electronic form. The graphics for this report were generated by David Lanigan and Chris Newbill.

Bruce Williams

Bruce Bjornstad

Ron Schalla

Bill Webber 


\section{Acronyms}

$\begin{array}{ll}\text { CAMIS } & \text { Computer-Automated Mapping Information System } \\ \text { DOE } & \text { U.S. Department of Energy } \\ \text { Ecology } & \text { Washington State Department of Ecology } \\ \text { EPA } & \text { U.S. Environmental Protection Agency } \\ \text { HGIS } & \text { Hanford Geographical Information System } \\ \text { HGWMP } & \text { Hanford Groundwater Monitoring Project } \\ \text { N.A. } & \text { not applicable } \\ \text { NAVD88 } & \text { North American Vertical Datum of 1988 } \\ \text { PGM } & \text { pre-Missoula gravel } \\ \text { PNLGIS } & \text { PNNL Geographical Information System } \\ \text { PNNL } & \text { Pacific Northwest National Laboratory } \\ \text { PPU } & \text { Plio-Pleistocene unit } \\ \text { PPUcp } & \text { Plio-Pleistocene calcic paleosol facies association } \\ \text { SALDS } & \text { State Approved Land Disposal Site } \\ \text { TPA } & \text { Tri-Party Agreement } \\ \text { U Pond } & \text { 216-U-10 Pond }\end{array}$




\section{Contents}

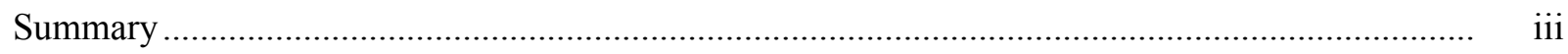

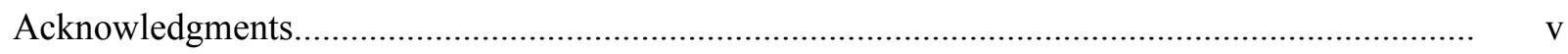

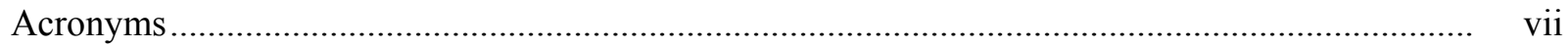

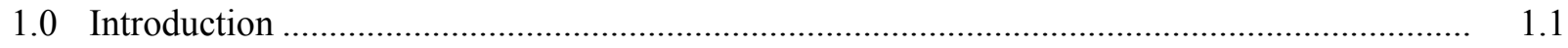

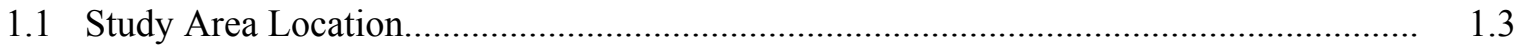

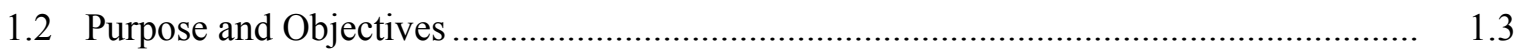

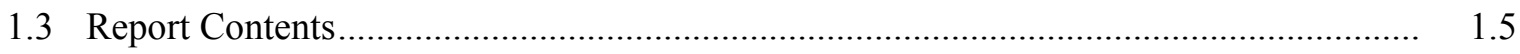

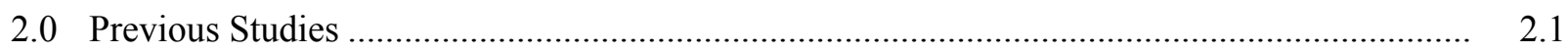

3.0 Hydrogeologic Setting of the 200-West Study Area ........................................................ 3.1

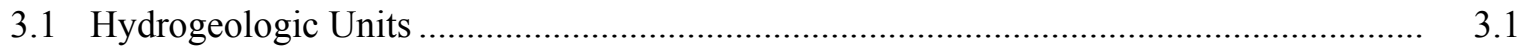

3.1.1 Columbia River Basalt Group ......................................................................... 3.1

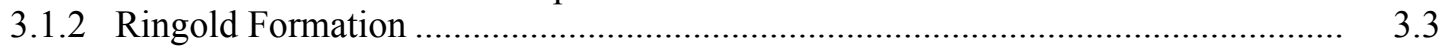

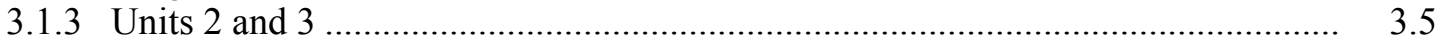

4.0 Conceptual Groundwater Model .........................................................................

4.1 Hydrogeologic Framework .............................................................................. 4.1

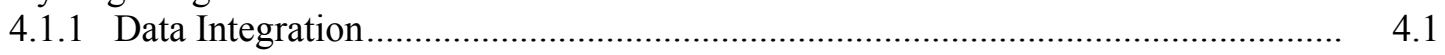

4.1.2 Maps and Cross Sections ............................................................................ 4.3

4.1.3 Observations ......................................................................... 4.14

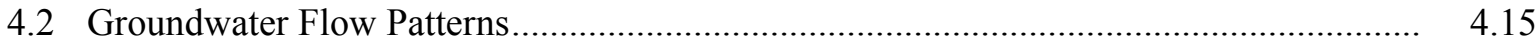

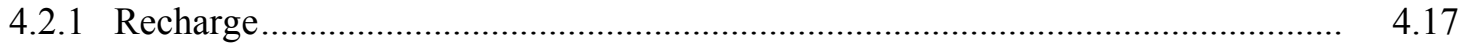

4.2.2 Groundwater Flow in the Hanford Unconfined Aquifer ................................... 4.18

4.2.3 Groundwater Flow in the Confined Ringold Aquifer......................................... 4.19

4.2.4 Intercommunication of Suprabasalt Aquifers................................................... 4.20

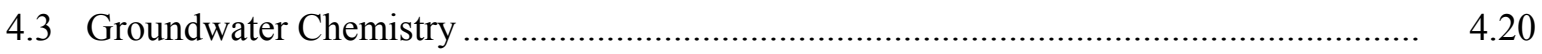

4.3.1 Uppermost-Unconfined Aquifer...................................................................... 4.21

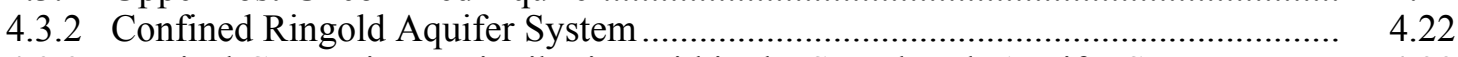

4.3.3 Vertical Contaminant Distribution within the Suprabasalt Aquifer System ......... 4.22

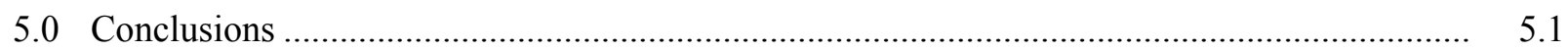

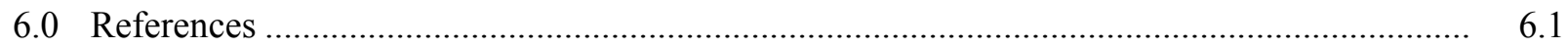

Appendix A - 200-West Area Hydrogeologic Database ........................................................... A.1

Appendix B - Units and Open Interval Data Tables for 200-West Area.................................... B.1 


\section{Figures}

1.1 Annual Volumes of Major Liquid Effluent Streams Discharged to Hanford Site

Soil Column

1.2 200-West Area Location on the Hanford Site, Washington...

1.3 200-West Study Area Boundary

3.1 Comparison of Hydrogeologic and Geologic Classifications.

3.2 Facies Distribution for the Plio-Pleistocene Unit Within the Central Pasco Basin and 200-West Study Area

4.1 Schematic Hydrogeologic Cross Section of Line 1-1'.

4.2 Schematic Hydrogeologic Cross Section of Line 2-2' - 200-West Area and Vicinity

4.3 Schematic Hydrogeologic Cross Section of Line 3-3' - 200-West Area and Vicinity

4.4 Schematic Hydrogeologic Cross Section of Line 4-4' - 200-West Area and Vicinity

4.5 Schematic Hydrogeologic Cross Section of Line 5-5' - 200-West Area and Vicinity

4.6 Topographic Illustration of Pleistocene Flood Channels and the Present-Day Columbia River Channel Pathways, with Outlines of the 200-West and East Study Areas, Hanford Site, Washington

4.7 Depth Distribution of Key Contaminants, Well 699-36-70A, 200-West Area

4.8 Depth Distribution of Key Contaminants, Well 299-W22-50, Waste Management Area S-SX

4.9 Depth Distribution of Key Contaminants, Well 299-W10-W4, Waste Management Area T

4.10 Depth Distribution of Key Contaminants, Well 299-W14-14, Waste Management Area TX-TY

4.11 Single-Source Groundwater Contaminant Plume Conceptual Model for the 200-West Area Illustrating Hypothetical Plume Migration.

4.12 Multiple-Source Contaminant Plume Conceptual Model for the 200-West Area Illustrating Vertical Displacement of Pre-Existing Plumes by More Recent Contaminant Source. 
4.13 Groundwater Contaminant Plume Conceptual Model for State-Approved Land Disposal Site Illustrating Vertical and Horizontal Influence on Upper Unconfined Aquifer

4.14 Tritium Concentration Trends in Wells Nearest to the State-Approved Land Disposal Site through August 2000.

4.15 Vertical Contaminant Dispersement in Deep Well 699-48-77C.

\section{Table}

3.1 Hydraulic Conductivities for Major Hydrogeologic Units

\section{Plates}

1 Base Map - 200-West Area and Vicinity

2 Top of Basalt Structure Contour Map, 200-West Area and Vicinity

3 Top of Ringold Formation Unit 9 Structure Contour Map, 200-West and Vicinity

4 Ringold Formation Unit 9 Gross Interval Isopach Map, 200-West and Vicinity

5 Top of Ringold Formation Unit 8 Structure Contour Map, 200-West and Vicinity

6 Ringold Formation Unit 8 Gross Interval Isopach Map, 200-West and Vicinity

7 Ringold Formation Unit 5 Structure Contour Map, 200-West and Vicinity

8 Ringold Formation Unit 5 Gross Interval Isopach Map, 200-West and Vicinity

9 Hydrogeologic Cross Sections L1 and L2, 200-West and Vicinity

10 Hydrogeologic Cross Section L3, 200-West and Vicinity

11 Hydrogeologic Cross Section L4 and L5, 200-West and Vicinity

12 Water-Table Change Map, 1979 through 2001

13 Uppermost-Unconfined Aquifer Thickness Map, 200-West and Vicinity

14 Revised Water-Table Map, Calendar Year 2000, 200-West and Vicinity

15 Composite Map Illustrating Several Regional Contaminant Plumes, 200-West and Vicinity 


\subsection{Introduction}

This report is the second in a two-part series of hydrogeologic reports, which together cover the entire Central Plateau. The first report, titled Revised Hydrogeology for the Suprabasalt Aquifer System, 200-East Area and Vicinity, Hanford Site, Washington (Williams et al. 2000), updates the hydrogeologic conceptual model and documents recent groundwater changes occurring in the 200-East Area. This report covers the adjacent 200-West and the adjoining 600 Area and refines and revises the suprabasalt hydrogeology from previously issued studies and reports.

The largest inventory of radiochemical waste on the U.S. Department of Energy (DOE) Hanford Site is stored in the Central Plateau in single- and double-shell tanks and contained within the soil column above the water table or vadose zone. The DOE, U.S. Environmental Protection Agency (EPA), and Washington State Department of Ecology (Ecology) have determined that this waste poses a potential hazard to the human health and the environment.

In addition to the risk of groundwater contamination resulting from future releases from the inventories mentioned previously, past-practice activities (spent nuclear fuel processing and separation) between 1940 through the mid-1990s disposed large quantities of contaminated liquid effluent to the ground via cribs, ponds, and ditches (Figure 1.1). A large portion of this effluent has migrated through the vadose zone into the groundwater. Contaminants migrating with this effluent have resulted in the groundwater plumes being tracked out of the Central Plateau via two, well-established flow paths, one to the southeast of B Pond and one to the north between Gable Mountain and Gable Butte (Gable Gap).

The Hanford Groundwater Monitoring Project (HGWMP), administered by Pacific Northwest National Laboratory (PNNL), has been tasked with revising and updating the hydrogeology and the existing conceptual groundwater flow model to better explain groundwater conditions and mechanisms within the suprabasalt aquifer system beneath the Central Plateau. This supports efforts to gain a better understanding of potential risk from vadose contamination to the site and the river via the groundwater flow path.

To understand and evaluate the groundwater flow regime, groundwater samples are collected from monitoring wells and analyzed for selected constituents, (i.e., groundwater indicator parameters, anions, cations, radionuclides, isotopic composition). To make a valid evaluation of groundwater data, it is necessary to compare data from the same hydrogeologic unit along the groundwater flow path of interest. The hydrogeologic unit monitored is a function of the local hydrologic conditions, well construction, sampling method, and sampling procedure. It is possible for groundwater samples from adjacent and nearby wells to be representative of distinct hydrogeologic units at different depths or a composite of groundwater from multiple hydrogeologic units. Therefore, it is imperative that each sample be evaluated to ensure it is representative of the hydrogeologic unit of interest and is interpreted accordingly. 


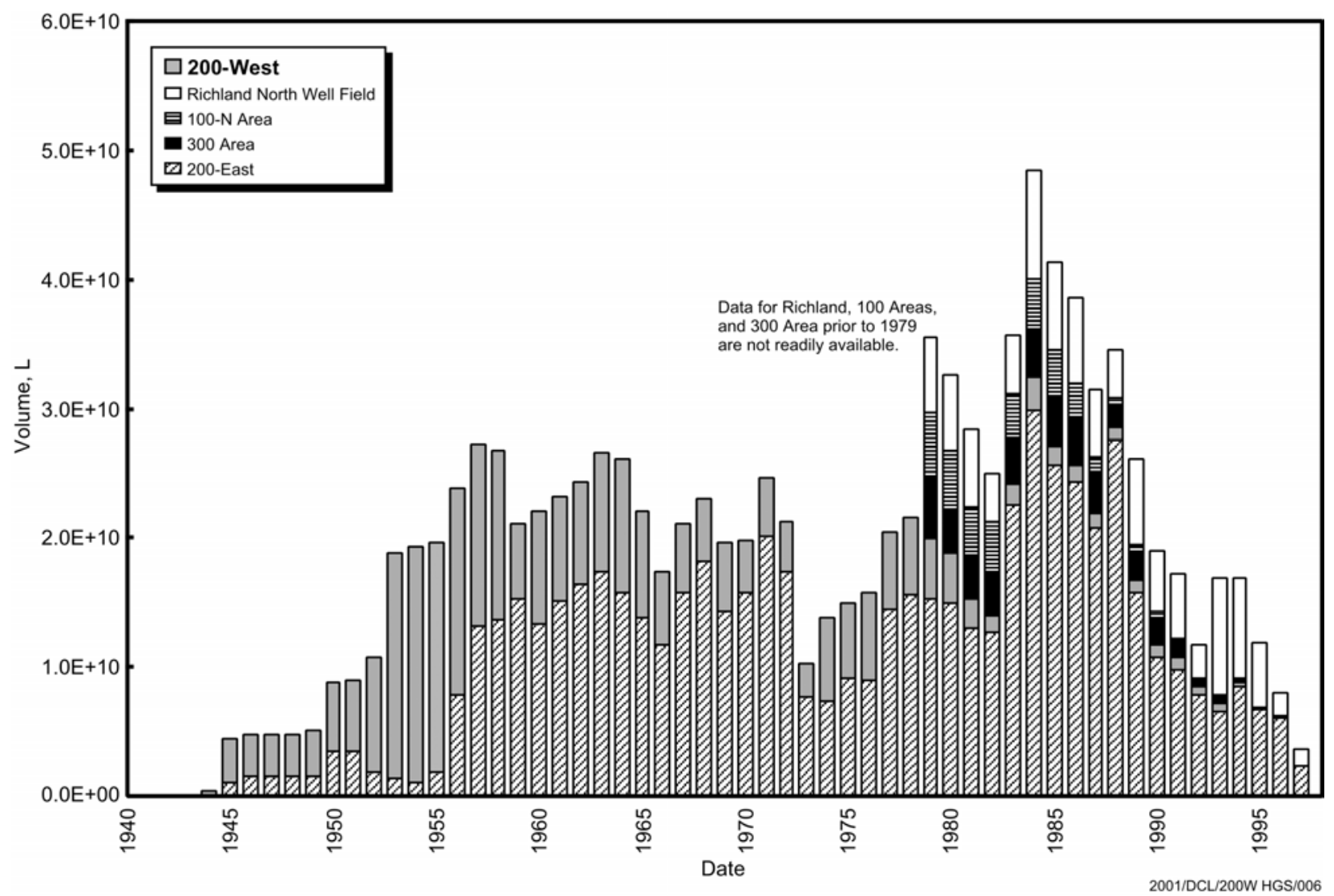

Figure 1.1. Annual Volumes of Major Liquid Effluent Streams Discharged to Hanford Site Soil Column

The suprabasalt aquifer system includes all the saturated geologic units or strata that occur above Columbia River basalt bedrock. This aquifer system is the most significant and direct pathway for contaminants disposed to the ground (via cribs, ponds and ditches, leaking single-shell tanks, or through accidental discharge) to migrate off the Hanford Site and effect human health and the environment (via the Columbia River).

The geologic units that make up the subsurface environment form the physical framework that governs groundwater movement in space and time. The hydraulic properties (i.e., the ability of a geologic unit to transmit groundwater, and the extent or hydraulic continuity, of the units) all relate to define potential groundwater pathways to the river. To understand groundwater movement in the subsurface, laterally extensive geologic units are categorized into hydrogeologic units (flow units) consisting of an aquifer, an aquitard (confining unit), or a combination of aquifers and aquitards that define a distinct hydrologic system.

A detailed evaluation and integration of existing and new data was used to enhance the previous conceptual groundwater flow model (Thorne et al. 1994) and to differentiate the multiple hydrogeologic units and the related groundwater flow regimes that exist beneath and surrounding the 200-West Area. 
Without this detailed conceptual model, it is difficult to determine where (both vertically and horizontally) the contaminants are, how they are moving, where and when they may impact the public, and how to track and monitor them.

Throughout most of the 200-West study area, groundwater is monitored only within the upper $10 \mathrm{~m}$ (35 ft) of an aquifer even though the aquifer is up to $80 \mathrm{~m}(262 \mathrm{ft})$ thick, and contamination has been detected to its base. This preferential sampling of the upper portion of the unconfined aquifer limits the interpretation and assessment of contaminant transport and model predictions.

\subsection{Study Area Location}

The study area includes the 200-West Area and vicinity and is located within an elevated area designated the Central Plateau in the west-central part of the Hanford Site in south-central Washington

(Figure 1.2). The Hanford Site is located within the Pasco Basin, a geographic and structural basin within the Columbia Basin (DOE 1988).

The study area boundaries (Figure 1.3 and Plate 1) include the natural structural features of Gable Butte, a sub aerial basalt ridge (anticline) to the north, and the buried Cold Creek Fault to the west. The eastern boundary overlaps the 200-East Area study area boundary (Williams et al. 2000), which is just west of the 200-East Area. The southern boundary is arbitrarily based on where the hydrogeologic units dip deep below the upper unconfined aquifer and do not affect groundwater movement beyond the study area (near the axis of the Cold Creek syncline). For this study, regional geologic interpretations published by Lindsey (1995), where applicable, were used to correlate the hydrogeologic units within the study area.

The Ringold Unit 5 gravel is the uppermost saturated hydrogeologic unit in the study area. This study focuses on the Ringold Unit 5 gravel and underlying units. It does not attempt to correlate details of the units that are unsaturated (vadose zone). See other reports (Last et al. 1989; Connelly et al. 1992a; Lindsey et al. 1992; Slate 1996; Johnson et al. 1999; Wood et al. 2001) for more detailed information on the vadose zone.

\subsection{Purpose and Objectives}

The purpose of this study was to update and refine the conceptual groundwater flow and contaminant transport model for the 200-West Area and vicinity, so that we can better predict groundwater flow and contaminant transport. The specific objectives of the project are to:

- provide a detailed, accurate, and comprehensive 200-West Area hydrogeologic conceptual model in support of the Hanford Groundwater Monitoring Project three-dimensional numerical groundwater model (Wurstner et al. 1995). This model will be used to verify present and predict future groundwater conditions, including flow and related groundwater contaminant pathways, rates of migration, and contaminant distribution within the aquifer system. Results from these model simulations can be strategic in defining those areas where groundwater monitoring needs to be enhanced, areas where monitoring may be reduced, and areas where additional characterization is needed. These results also provide valuable input to define DOE's groundwater cleanup strategies. 


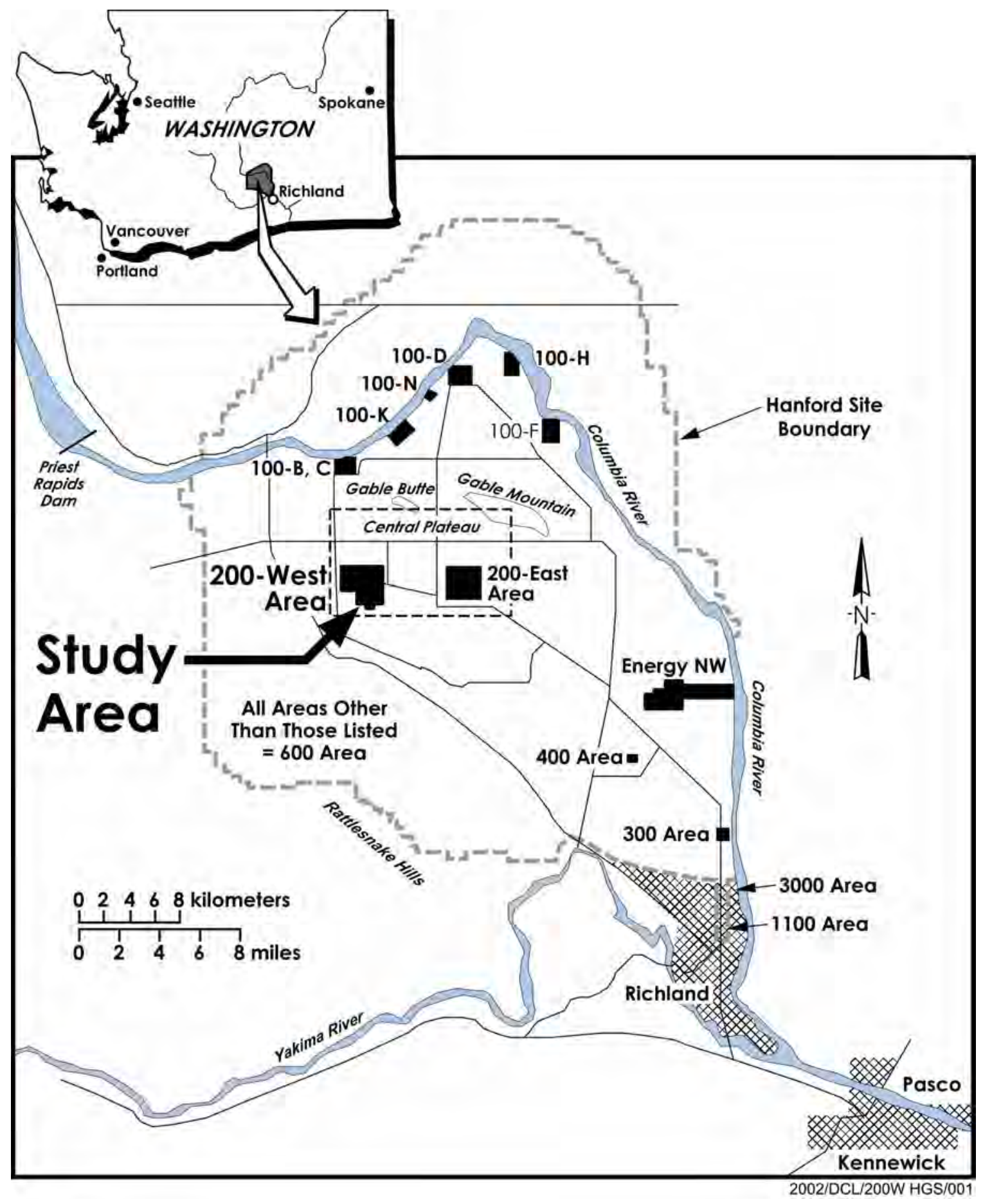

Figure 1.2. 200-West Area Location on the Hanford Site, Washington 


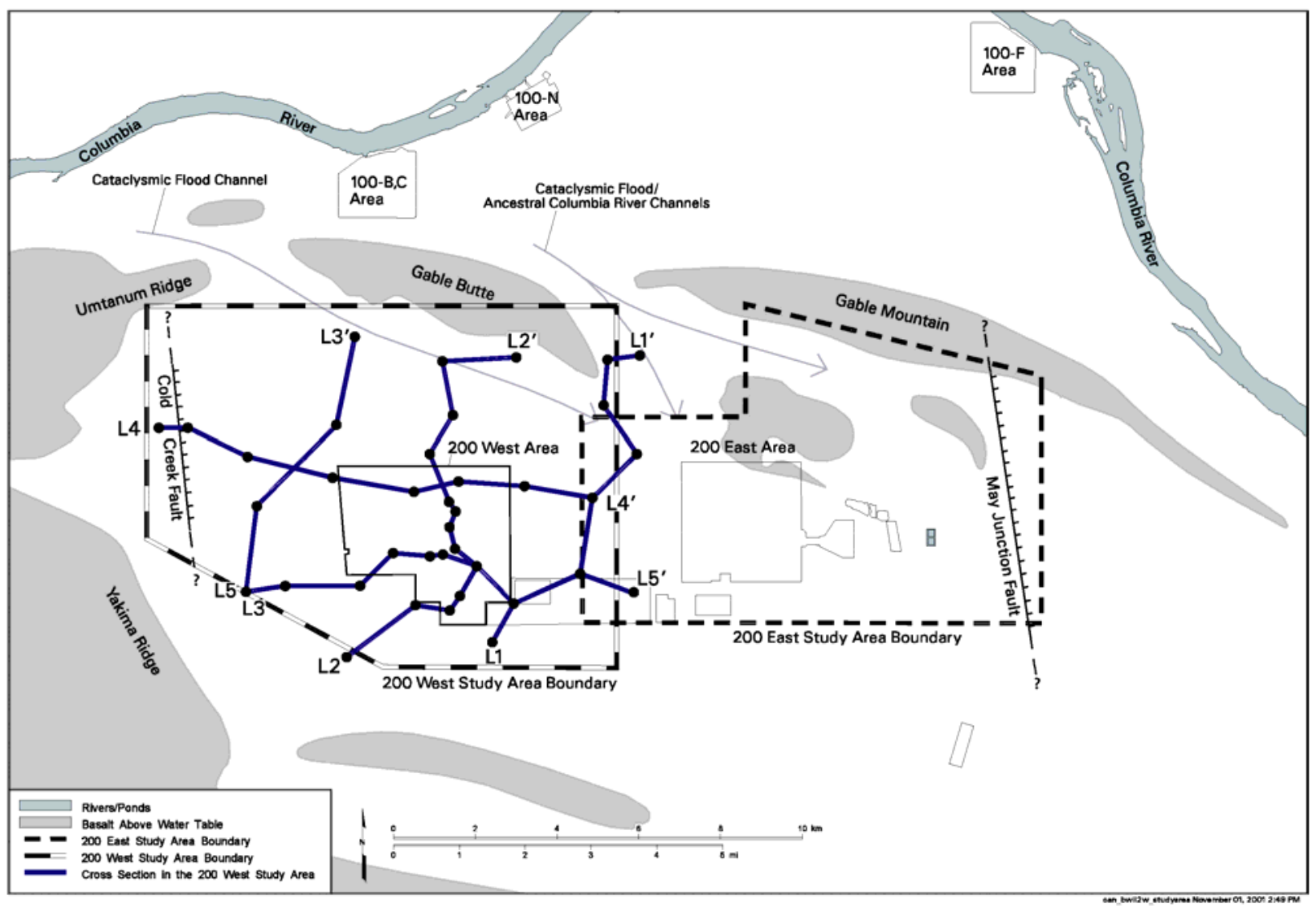

Figure 1.3. 200-West Study Area Boundary

- document how groundwater flow and contaminant migration patterns and rates are changing in the 200-West Area as water levels decline. Recent water-level declines within the suprabasalt aquifer system have placed the water table in different hydrogeologic units and resulted in new groundwater flow patterns. These changes warrant a closer, detailed look and necessitate treating the high- and low-hydraulic conductivity layers as separate hydrogeologic units for predicting groundwater and contaminant movement along preferential flow paths. Groundwater contaminant flow paths will likely be altered by hydrogeologic conditions within the aquifer system as the water table continues to decline.

\subsection{Report Contents}

Previous reports, investigations, and conceptual models pertaining to the geology, hydrology, and hydrogeology of the suprabasalt aquifer system were used as a baseline from which to develop an updated conceptual groundwater flow model and a comprehensive look at the suprabasalt hydrogeology of the 200-West Area. Section 2.0 of this report describes these previous studies. Section 3.0 describes the hydrogeology of the 200-West Area. Section 4.0 presents the development of the updated conceptual hydrogeologic model and a revised water-table map. It discusses possible groundwater flow patterns 
and vertical contaminant distributions. Study conclusions are presented in Section 5.0. References are included as Section 6.0. Appendix A provides hydrogeologic unit data for selected wells within the 200-West study area; Appendix B includes units and open interval data tables for the 200-West Area. 


\subsection{Previous Studies}

The regional geologic setting of the Pasco Basin and the Hanford Site have been described by Myers et al. (1979), DOE (1988), Delaney et al. (1991), and Lindsey et al. (1994). The geologic setting for the 200 Areas has been investigated and reported by Brown (1959), Tallman et al. (1979, 1981), Last et al. (1989), and most recently, by Lindsey et al. (1992) and Lindsey (1995). Lindsey (1995) provides a stratigraphic interpretation for the Ringold Formation based on facies associations and defines the areal extent of these suprabasalt units in the Pasco Basin.

The regional hydrogeology was first presented in Gephart et al. (1979). The first detailed hydrologic study of the 200 Areas was presented by Graham et al. (1981) and has been updated and modified by Connelly et al. (1992a). A three-dimensional conceptual model for the entire Hanford Site unconfined aquifer system is also presented in Thorne et al. (1993); Vermeul et al. (2001); and Cole et al. (2001). Early groundwater monitoring results in the 200 Areas were reported by Wilbur et al. (1983) and currently are reported annually in the Hanford Site groundwater monitoring reports (e.g., Hartman et al. 2001).

The most recent 200-West Area hydrogeologic report published at Hanford was Connelly et al. (1992a). They provided the most comprehensive hydrogeologic model for the 200-West Area, combining data from both the vadose and saturated zones. Results of Connelly et al. (1992a) established the 200-West Area hydrogeologic framework, which is the interpretation most similar to the conceptual model described in this report. The hydrogeologic conceptual model presented by Connelly describes all the saturated units above the basalt (suprabasalt sediments) as the "uppermost aquifer" in the 200-West Area and defines the regionally most extensive uppermost-confined aquifer as the Rattlesnake Ridge interbed aquifer. Swanson et al. (1999) also provides a recent update of the hydrogeologic conceptual model for the carbon tetrachloride and uranium/technetium plumes in the 200-West Area.

Connelly et al. (1992a) briefly describe the basalt and suprabasalt geology and areal extent of the suprabasalt geologic units including the hydraulic properties of those units within the 200-West Area. The hydrogeologic model describes the relationship between Hanford and Ringold formation sediments as resulting from a combination of both erosional and depositional mechanisms. The erosional area is described as an area of "off-lap" deposition having a northwest-southeast trend through the 200-West Area.

Regional groundwater flow conditions prior to 1992 are generally described in Connelly et al. (1992a) as flowing from west to east between 200-West and 200-East Areas. Local groundwater flow is described as a radial outward flow due to artificial recharge mounds from the central and southern portion of the 200-West Area that trend regionally toward the east. Groundwater conditions, including flow and contaminant distributions for the uppermost-unconfined aquifer, are currently reported in the background document (a summary of site hydrogeology) for the Hanford Site Groundwater Monitoring annual report (Hartman et al. 2001). 
Groundwater contaminant plumes for selected chemical and radioactive contaminants detected in the 200-West Area are graphically presented and briefly described for the uppermost aquifer in Connelly et al. (1992a). Connelly et al. (1992a) also provides a three-dimensional graphical interpretation of the major lithologic units within the uppermost aquifer system. 


\subsection{Hydrogeologic Setting of the 200-West Study Area}

The base of the suprabasalt aquifer in the 200-West Area consists of the Elephant Mountain Member of the Saddle Mountains Basalt, Columbia River Basalt Group (bedrock; Reidel and Fecht 1981). The suprabasalt sediments include the Ringold Formation, Plio-Pleistocene Unit, and Hanford formation (informal name) sedimentary sequences which overlie the basalt. For a detailed geographic and geologic description of the stratigraphic units present in the 200-West Area, see Lindsey et al. (1992).

In the northern half of the study area, erosion associated with Pleistocene cataclysmic flooding created a scoured surface that was later buried. Within most of this buried paleochannel and scoured area, Ringold-age sediments have been reworked and/or removed, and younger, Hanford formation cataclysmic flood deposits of sand and gravel locally lie directly on top of basalt. South of the flood channel, up to $100 \mathrm{~m}$ (328 ft) of flood deposits accumulated on top of Cold Creek Flood Bar. ${ }^{1}$

\subsection{Hydrogeologic Units}

Two separate Hanford Site stratigraphic classifications are available (Figure 3.1); one developed by Lindsey (1995) is based on lithology (labeled Geology Column), and the second, developed by PNNL (Wurstner et al. 1995; Thorne et al. 1993), is the hydrogeologic stratigraphy (labeled Hydrogeologic Column) that combines the geology with the hydrologic properties (see also Wurstner et al. 1995). This report uses PNNL's hydrogeologic classification because it is more applicable to the problem of addressing groundwater movement in the suprabasalt sediments. A hydrogeologic summary of these units is presented below. This classification is consistent with the site three-dimensional computer models that use this classification and the revised hydrogeology report for the 200-East Area (Williams et al. 2000).

\subsubsection{Columbia River Basalt Group}

The Elephant Mountain Member of the Saddle Mountains Basalt, dated at 10.5 Ma (million years), is a Miocene-age, medium-to-fine-grained tholeiitic continental flood basalt. Beneath the 200 Areas of the Hanford Site, the Elephant Mountain Member consists of one to two flows and ranges in thickness from 20 to $30 \mathrm{~m}$ (65.6 to $98 \mathrm{ft})$ (Reidel and Fecht 1981).

The uppermost surface of the Elephant Mountain Member (basalt) is considered the base of the suprabasalt aquifer system (bedrock) because of its low permeability relative to the overlying sediments. This surface is considered to be a groundwater no-flow boundary for most purposes. The basalt surface beneath the 200-West Area dips south-southwest forming the southern limb of the Gable Mountain-Gable Butte anticline and the northeast flank of the Cold Creek syncline (after Fecht et al. 1987) (Plate 2).

\footnotetext{
${ }^{1}$ Bjornstad, B. N., G. V., Last, G. A. Smith, K.A. Lindsey, K. R. Fecht, S. P. Reidel, D. B. Horton, and B. A. Williams. Draft 2001. Proposed Standardized Stratigraphic Nomenclature for Post-Ringold-Age Sedimentary Deposits Within the Central Pasco Basin. White Paper, Pacific Northwest National Laboratory, Richland, Washington.
} 


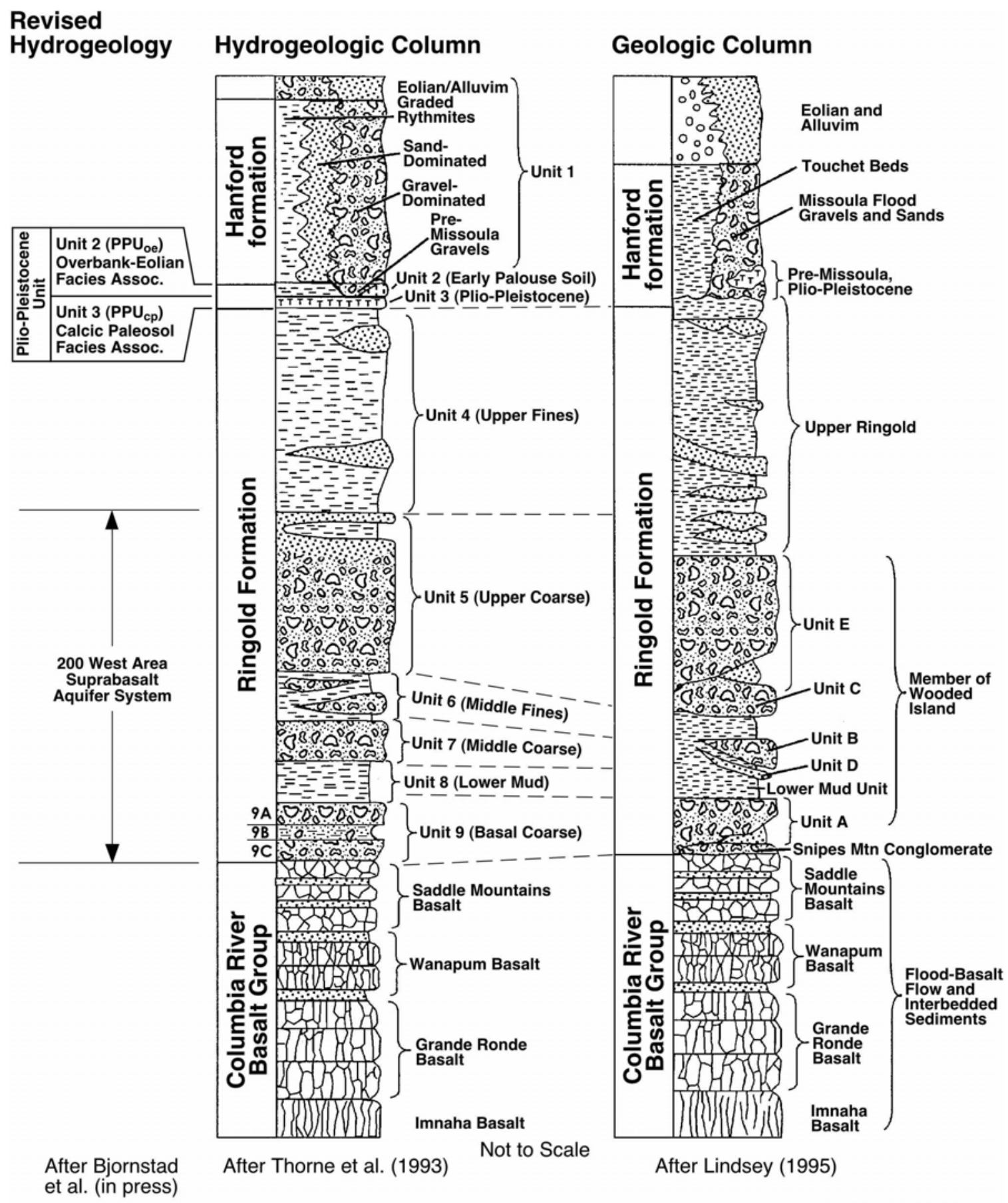

2002/DCL/200W HGS/002

Figure 3.1. Comparison of Hydrogeologic and Geologic Classifications ${ }^{1}$

\footnotetext{
${ }^{1}$ Bjornstad, B. N., G. V., Last, G. A. Smith, K.A. Lindsey, K. R. Fecht, S. P. Reidel, D. B. Horton, and B. A. Williams. Draft 2001. Proposed Standardized Stratigraphic Nomenclature for Post-Ringold-Age Sedimentary Deposits Within the Central Pasco Basin. White Paper, Pacific Northwest National Laboratory, Richland, Washington.
} 
Intercommunication of groundwater between the uppermost basalt-confined aquifer and overlying suprabasalt aquifer system has been documented in some areas of the Hanford Site but does not occur beneath the 200-West Area (Reidel and Fecht 1981). One of these areas of intercommunication is identified in the extreme northeastern part of the study area in Gable Gap, where ancestral Columbia River and/or cataclysmic flooding had eroded away the upper basalt units exposing the lower units and interbeds to suprabasalt aquifers (Spane and Webber 1995).

The basalt geology on Gable Butte, which is structurally elevated above the unconfined aquifer, consists of a complex network of faults and anticlines that are not discussed here. Reidel and Fecht (1981) provide a more detailed discussion.

\subsubsection{Ringold Formation (Units 4 through 9)}

Units 4 through 9 correspond to the Ringold Formation (Figure 3.1). These units represent continental fluvial and lacustrine sediments deposited on the Elephant Mountain Member by ancestral Columbia and Clearwater-Salmon rivers during late Miocene to Pliocene time (DOE 1988). From the oldest to youngest (bottom to top of the section), the stratigraphic intervals are Unit 9 fluvial gravel, Unit 8 composed of the paleosol/overbank facies beneath lacustrine fine-grained facies (Bjornstad 1984; DOE 1988; Last et al. 1989; Bjornstad 1990), Unit 5 fluvial gravel, and Unit 4.

Units 4 through 9 consist of intercalated layers of indurated to semi-indurated and/or pedogenically altered sediment, including clay, silt, fine-to-coarse-grained sand, and granule-to-cobble gravel. Within the 200-West Area and vicinity, this sequence consists of four distinct stratigraphic intervals designated Units 4, 5, 8, and 9. Units 4, 5, 8, and 9 correspond generally to Lindsey's Ringold Formation upper unit (silt and sand), fluvial gravel Unit E, lower mud unit and fluvial gravel Unit A, respectively (Figure 3.1). Units 4 and 5 (Lindsey's Upper Ringold Unit and Unit E) are not present in the northern portion of the 200-West study area. Units 6 and 7, which correspond to Lindsey's Ringold Formation Units B, C, and D, are not present in the 200-West study area (Thorne et al. 1994).

\subsubsection{Unit 9}

The 200-East Area hydrogeologic report (Williams et al. 2000) subdivided Unit 9 (Unit A) into three hydrogeologic units (designated as Units 9A, 9B, and 9C) based on markedly different lithologic descriptions and hydraulic properties. In this study, Unit 9 is undifferentiated except for the very northeast portion of the study area because data do not support the subdivision of the Unit 9 throughout the entire study area.

Unit 9 dips consistently to the south-southwest, roughly comparable to the basalt structure (see Plate 3). Unit 9 increases in thickness from north to south into the Cold Creek syncline (Plate 4), suggesting deposition in an environment of continued structural growth of the Pasco Basin during Ringold time (Bjornstad 1984, 1985; DOE 1988).

The north-northeastern extent of Unit 9 is approximate and is delineated as the erosional limit of cataclysmic flooding that traversed across the uplifted Gable Butte anticlinal area (see Plates 1, 3, and 4). 
In the scoured area, interpreted to be north of the erosional boundary, Units 4, 5, 8, and 9 are all or partially removed and/or reworked within the area of erosion.

Aquifer testing, primarily in Unit 9, reveals that this unit has a lower hydraulic conductivity than the uppermost-unconfined aquifer, which is composed primarily of Unit 5 (Ringold Formation Unit E) throughout most of the study area and Unit 1 (Hanford formation gravel and sand), which forms the uppermost-unconfined aquifer along the very northern edge of the study area just south of Gable Butte within the area scoured by cataclysmic flooding.

\subsubsection{Unit 8 (Lower Mud Unit)}

Unit 8 correlates with the lowermost fine-grained sequence of Lindsey's Wooded Island Member of the Ringold Formation designated the Lower Mud Unit (Figure 3.1). Unit 8 is composed of a thick sequence of fluvial overbank, paleosol, and lacustrine silts and clay with minor sand and gravel. More detailed descriptions of Unit 8 (the lower mud unit) can be found in Lindsey (1995).

Unit 8 forms the most significant confining unit within the suprabasalt aquifer system at the Hanford Site (Williams et al. 2000). Unit 8 separates the saturated sediments of the suprabasalt aquifer system into an uppermost-unconfined aquifer, often referred to as the Hanford unconfined aquifer, and a lower confined aquifer referred to as the confined Ringold aquifer (Williams et al. 2000). This study shows the confined Ringold aquifer is composed of Unit 9 gravel and the uppermost-unconfined aquifer system includes saturated sediments above Unit 8 (the Ringold lower mud unit) where Unit 8 exists. Where Unit 8 is missing, the uppermost-unconfined aquifer includes all of the saturated sediments above the top of basalt (i.e., Units 1, 5, and 9).

Unit 8 is present throughout most of the 200-West study area (Lindsey 1995). However, as Lindsey and others have indicated, Unit 8 is not present on the Gable Mountain anticline, which includes Gable Gap and the region just south extending to the northern boundary of the 200-West Area. Geologic, geophysical, and hydraulic data evaluated for this report indicate that where channeling occurs within the study area, erosion appears to have scoured into and completely removed all Unit 8 (the Ringold lower mud unit) and Unit 5 (Ringold Unit E), with the possible exception of small, localized remnants. This report proposes an erosional limit for the Ringold Unit 8 (Plate 5).

Where present in the 200-West Area, Unit 8 is up to $26 \mathrm{~m}(85 \mathrm{ft})$ thick and dips southwest into the Cold Creek syncline roughly conformable to the basalt surface (Plate 6). The revised structure contour map of Unit 8 illustrates that it is elevated above the water table northeast of the 200-West Area (Plate 5). In the area, where Unit 8 is at or above the water table, it is mapped as a hydraulic barrier (no flow boundary) similar to the basalt surface (see Section 3.1.1). Wurstner et al. (1995) states that hydraulic conductivity measured in Unit 8 (the Ringold lower mud unit) ranges from $3 \times 10^{-4}$ to $9 \times 10^{-2} \mathrm{~m} / \mathrm{d}$, which is several orders of magnitude lower than that measured in the Hanford unconfined aquifer (Unit 1 through Unit 5; e.g., $1 \times 10^{-1}$ to $1,000,000 \mathrm{~m} / \mathrm{d}$ ) and on average is over two orders of magnitude lower than measured for the confined Ringold aquifer system (Unit 9A/C; i.e., $1 \times 10^{-1}$ to $2 \times 10^{2} \mathrm{~m} / \mathrm{d}$ ). ${ }^{1}$

\footnotetext{
${ }^{1}$ Results are values reported by Wurstner et al. (1995) and are reported here for trending purposes only.
} 
Interpretations presented in this report, using hydrochemistry and hydrologic data, the hydrogeologic continuity and thickness of Unit 8, indicate that groundwater within the Hanford unconfined aquifer and confined Ringold aquifer system does not flow vertically through Unit 8. However, along the lateral boundary of Unit 8 where it is absent, either due to depositional thinning or removed by erosion, groundwater from the confined Ringold aquifer system may be in communication with groundwater from the uppermost-unconfined aquifer.

\subsubsection{Unit 5 (Unit E)}

Within the 200-West Area, Unit 5 (the Ringold Formation Unit E) is the uppermost Ringold unit in the unconfined aquifer (Figure 3.1) and is composed primarily of fluvial gravel that grades upward into Unit 4 (interbedded fluvial sand and silt of the Ringold Unit 4) (Lindsey 1995).

Unit 5 overlies Unit 8 (the Ringold lower mud unit) and is present everywhere except the very northeastern part of the study area where its up-dip limit is interpreted to be the same as the Unit 8 (the Ringold lower mud unit) limit as defined by the cataclysmic flood channel erosional boundary (Plates 7 and 8). This interpretation is slightly different from previous work and suggests that Unit 5 (Ringold Unit E) was also removed by erosion in this area during Pleistocene cataclysmic flooding events.

As described by previous authors, Unit 5 (Ringold Unit E) comprises the uppermost-unconfined aquifer over most of the 200-West Study Area. Most known contaminant plumes that emanate from the 200-West Area migrate through Unit 5 into the adjacent and overlying Unit 1 (Hanford formation) sand and gravel and continue their migration either northeast through Gable Gap or east into the 200-East Area.

\subsubsection{Unit 4 (Upper Ringold Unit)}

Lindsey (1995) provides the most detailed description of the Ringold Unit 4 (Upper Ringold unit). Swanson et al. (1999) provides a revised interpretation of the depositional extent of Unit 4. The Ringold Unit 4 is only locally present in the 200 -West Area, lies above the water table, and is not discussed in this report except where it is identified on cross sections.

\subsubsection{Units 2 and 3 (Plio-Pleistocene Unit)}

The Plio-Pleistocene unit is inferred to have a late-Pliocene to early-Pleistocene age based on stratigraphic position. The Plio-Pleistocene unit (PPU) represents deposits that accumulated within the Pasco Basin during the period between about 2 to 3 million years ago, which brackets two significant geologic events in eastern Washington. The older event is a regional base-level drop and subsequent incision of the Ringold Formation; the younger event is the initiation of ice-age cataclysmic flooding. During Ringold time, fluvial-lacustrine deposits filled the Pasco Basin up to an elevation of $275 \mathrm{~m}$ ( $900 \mathrm{ft}$ ). This former base level is indicated by a calcic paleosol, part of the Plio-Pleistocene unit, that developed on top of the Ringold Formation along the White Bluffs east of the study area. For reasons still unclear, accumulation of the Ringold Formation ceased abruptly about 3.4 million years ago, followed by a period of rapid downcutting and incision by the ancestral Columbia-Salmon-Clearwater River system (DOE 1988). 
Once a new base level was established at about the $100 \mathrm{~m}$ (328 ft) elevation, fluvial erosion ceased, once again permitting aggradation and backfilling to occur locally on the eroded Ringold landscape.

Several different facies associations are represented for the PPU. ${ }^{1}$ These include: 1) mainstreamalluvial, 2) calcic-paleosol, 3) sidestream-alluvial, 4) colluvial, and 5) overbank-eolian facies associations (Figure 3.2). The Plio-Pleistocene unit in the 200-West study area is represented by the calcic paleosol and sidestream-alluvial facies associations, which belong to Unit 3.

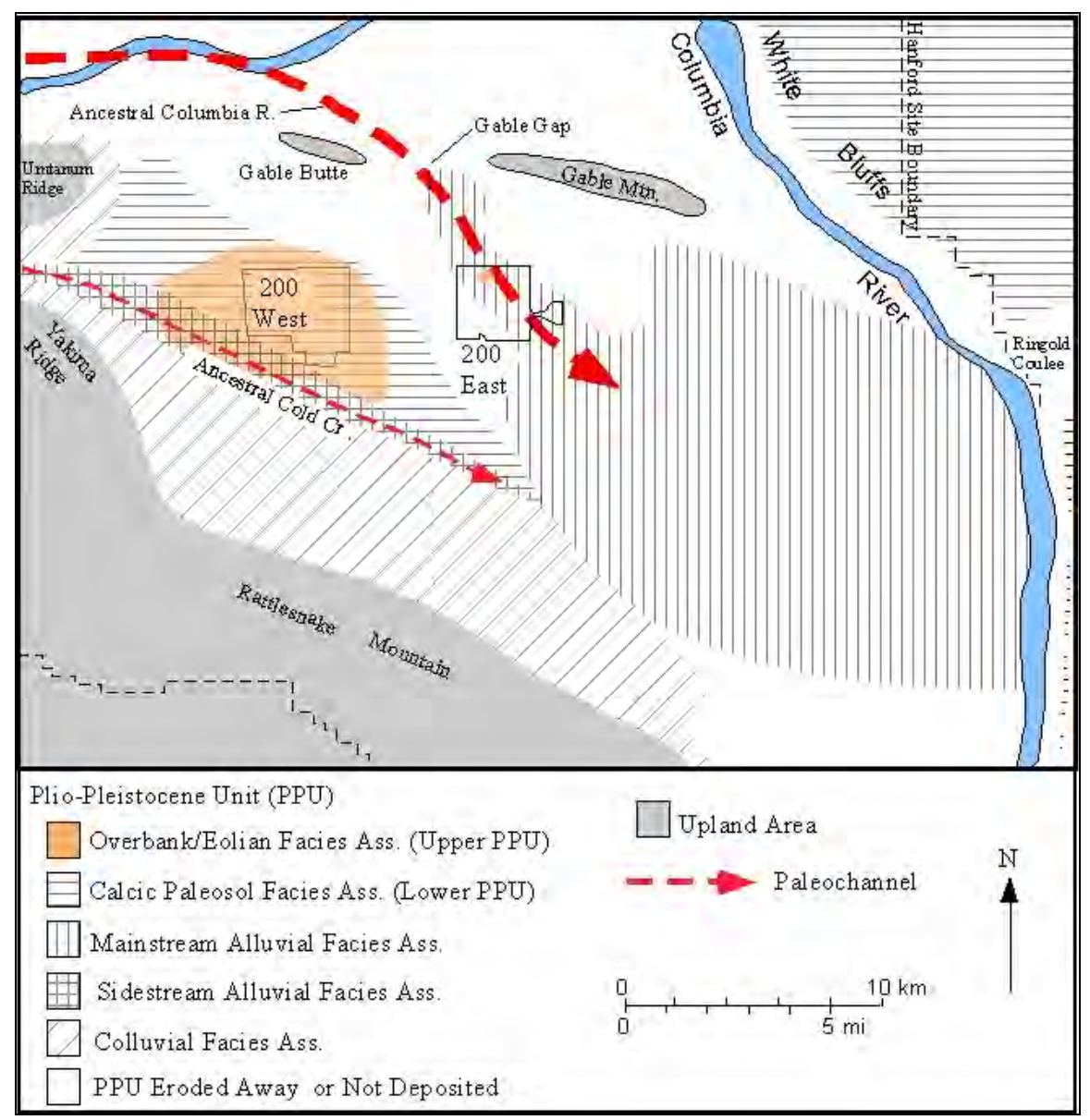

Figure 3.2. Facies Distribution for the Plio-Pleistocene Unit Within the Central Pasco Basin and 200-West Study Area. The PPU appears to be present beneath most of the Hanford Site, except in upland areas and where locally stripped away during Pleistocene cataclysmic flooding. ${ }^{2}$

\footnotetext{
${ }^{1}$ Bjornstad, B. N., G. V., Last, G. A. Smith, K.A. Lindsey, K. R. Fecht, S. P. Reidel, D. B. Horton, and B. A. Williams. Draft 2001. Proposed Standardized Stratigraphic Nomenclature for Post-Ringold-Age Sedimentary Deposits Within the Central Pasco Basin. White Paper, Pacific Northwest National Laboratory, Richland, Washington.

${ }^{2}$ Ibid.
} 
Locally overlying Unit 3 is a fine-grained overbank-eolian sequence considered to belong to the upper portion of the Plio-Pleistocene Unit. The overbank/eolian facies association is equivalent to early Palouse soil (Brown 1959; Tallman et al. 1979; DOE 1988; Last et al. 1989; Connelly et al. 1992a) or Unit 2 in the Hanford Site hydrogeologic model (Thorne et al. 1993; Wurstner et al. 1995).

In the west-central portion of the basin, basaltic sidestream alluvium partially filled the ancestral Cold Creek Valley just south of the 200-West Area during Plio-Pleistocene time (Figure 3.2). Beneath the 200-West Area itself, calcic paleosols developed in the interfluvial area between Cold Creek and the Columbia River. The 200-West Area did not undergo appreciable aggradation or degradation during Plio-Pleistocene time, allowing for the development of a well-developed calic paleosol sequence. Development of calcic paleosols in the 200-West Area abruptly terminated in the late Pliocene, soon after which these soils were deeply buried beneath layers of the PPU overbank/eolian facies association and cataclysmic flood deposits.

In the 200-West Area, the calcic sequence, also referred to as the lower Plio-Pleistocene unit, is easily differentiated from the overlying overbank-eolian sequence (upper Plio-Pleistocene unit). The lower Plio-Pleistocene unit is highly weathered and cementated with calcium carbonate, poorly sorted, and shows a decreased natural gamma activity compared to the upper Plio-Pleistocene unit, which is uncemented, well sorted, and has relatively high natural gamma activity.

\subsubsection{Unit 1 (Hanford formation)}

The Hanford formation is the informal name given to Pleistocene-age cataclysmic flood deposits in the Pasco Basin (Myers et al. 1979; DOE 1988; Baker et al. 1991; Lindsey et al. 1994). The Hanford formation forms a continuous blanket over the entire 200-West study area, except in the vicinity of flood-scoured Gable Butte. The Hanford formation consists predominantly of unconsolidated sediments that cover a wide range in grain size from pebble- to boulder-gravel, fine- to coarse-grained pebbly sand to sand, silty sand, and silt. Gravel clasts are composed of mostly subangular to subrounded basalt. Mineralogically, the sand fraction of the Hanford formation averages about $50 \%$ mafic rock fragments (i.e., basalt) and 50\% quartzfeldspar (Tallman et al. 1979). This mineral assemblage gives the Hanford formation its characteristic "salt and pepper" appearance, often noted in driller's and geologist's logs. Varying with location, the composition of flood gravel clasts may consist of $75 \%$ or more basalt.

Cataclysmic flood deposits have been classified into three facies types, these being gravel-, sand-, and fine-grained silt, which grade into one another, both vertically and laterally. Gravel-dominated facies, consisting of massive to large-scale, fore-set bedded, and poorly sorted mixtures of gravel, sand, and minor silt, are dominant along high-energy flood courses, such as the area along the northern boundary of the 200-West Area. Sand-dominated facies, consisting of mostly horizontally laminated, fine-to-coarse-grained, basaltic sand, lie adjacent to main flood channelways. Coarse-grained flood deposits generally contain a high concentration of dark-colored basalt clasts because of the extensive erosion and scouring of the Columbia River Basalt Group that occurred on the Channeled Scablands.

Last, fine-grained facies occur as sequences of rhythmic, graded beds that range from 0.1 to $1.0 \mathrm{~m}(0.3$ to $3.3 \mathrm{ft}$ ) thick and are characterized by horizontally to ripple-laminated sand that grades up into silt; these deposits formed as a result of slackwater deposition along the basin margins and in backflooded tributary 
valleys (DOE 1988; Baker et al. 1991). The source for most slackwater flood sediment is from eolian Palouse loess (Busacca and McDonald 1994), also eroded from the Channeled Scablands. The three facies may interfinger with or grade from gravel-to-sand- or sand-to-fine-grained facies but rarely from gravel-to-fine-grained facies.

In the northern portion of the study area, the Hanford formation directly overlies basalt; farther south it overlies the Plio-Pleistocene unit and Ringold Formation. The Hanford formation generally lies above the water table everywhere within the 200 -West study area except within a narrow, southeast-trending flood channel that runs along the south side of Gable Butte. While the Hanford formation plays a major role in the movement of groundwater and contaminants through the vadose zone, its influence on the movement of groundwater and contaminants through the suprabasalt aquifers beneath most of the 200-West Area and vicinity is indirect.

In the very northern portion of the study area, the uppermost-unconfined aquifer is composed mostly of Unit 1 (Hanford formation). As reported in Connelly, Thorne, and others, the Hanford formation hydraulic conductivity (K) values are highest of all the hydrogeologic units present (5-9) (Table 3.1, modified from Cole et al. 1997). Consequently, the Hanford formation in this area represents a discharge pathway for groundwater and contaminants in the uppermost-unconfined aquifer system beneath most of the 200-West Area and vicinity.

This report does not attempt to map or subdivide the vadose interval. Lindsey et al. (1992), Lindsey (1995), and Connelly et al. (1992a) provide regional descriptions of the Hanford facies and vadose zone in the 200-West Area.

Table 3.1. Hydraulic Conductivities for Major Hydrogeologic Units

\begin{tabular}{||l|c|l||}
\hline \multicolumn{1}{|c|}{ Hydrogeologic Unit } & \multicolumn{1}{|c||}{$\begin{array}{c}\text { Estimated Range of Saturated } \\
\text { Hydraulic Conductivities (m/d) }\end{array}$} & \multicolumn{1}{c||}{ Reference(s) } \\
\hline \hline $\begin{array}{l}\text { Unit 1 } \\
\text { (Hanford formation) }\end{array}$ & 1 to 1,000,000 & $\begin{array}{l}\text { Wurstner et al. (1995); Thorne and } \\
\text { Newcomer (1992) }\end{array}$ \\
\hline $\begin{array}{l}\text { Unit 5 } \\
\text { Ringold Formation Unit E) }\end{array}$ & 0.1 to 200 & $\begin{array}{l}\text { Wurstner et al. (1995); Thorne and } \\
\text { Newcomer (1992) }\end{array}$ \\
\hline $\begin{array}{l}\text { Unit 8 } \\
\text { Ringold Formation Lower } \\
\text { Mud Unit) }\end{array}$ & 0.0003 to 0.09 & $\begin{array}{l}\text { Wurstner et al. (1995); Thorne and } \\
\text { Newcomer (1992) }\end{array}$ \\
\hline $\begin{array}{l}\text { Unit 9 undifferentiated } \\
\text { Ringold Formation Unit A }\end{array}$ & 0.1 to 200 & $\begin{array}{l}\text { Wurstner et al. (1995); Thorne and } \\
\text { Newcomer (1992) }\end{array}$ \\
\hline Note: This table is modified from Cole et al. (1997). \\
\hline
\end{tabular}




\subsection{Conceptual Groundwater Model}

The primary objective of this study was to refine and update the hydrogeology and conceptual groundwater flow model for the 200 -West Area and vicinity. The revised hydrogeologic conceptual model for the adjoining 200-East Area is presented in Williams et al. (2000).

The primary components of the model are the 1) physical elements of the subsurface that form the hydrogeologic framework, and 2) groundwater that moves through this framework in response to hydraulic stresses within the aquifer. The previous conceptual model was used as the baseline and was expanded and refined to include all current and available suprabasalt hydrogeology and associated groundwater flow patterns beneath the 200-West Area and vicinity, using new data and re-evaluating existing data and reports from previous investigations. Major differences between this conceptual model and previous interpretations are provided below.

\subsection{Hydrogeologic Framework}

In some areas, the hydrogeologic interpretation described in this report differs from previous conceptual models. These differences generally are associated with the interpretation and definition of specific hydrogeologic units (as opposed to a purely geologic subdivision of units) and subsequent mapping options.

Because the focus of this study is to define the hydrogeology of the suprabasalt aquifer system, only saturated units within the study area are delineated. Stratigraphic sequences within the vadose zone have not been described in any detail in this study except in a few instances where a semi-regional marker or unit of significance is defined, (i.e., on cross sections).

\subsubsection{Data Integration}

The conceptual groundwater flow model presented here incorporates the latest geologic and hydrogeologic information available within the study area. Appendix A provides a partial listing of wells used for this study. This list is composed primarily of the deep boreholes that penetrated to the Ringold Unit 8 or below. Existing information files for many older wells were also used as part of this study. Where available, the following data and information were used for this interpretation:

- Geologic and borehole geophysical data were integrated with a review of selected soil samples archived in the Hanford Geotechnical Sample Library (2101-M Building, 200-East Area) to confirm data sets and ensure consistent correlations.

- Driller's logs and well-construction information were evaluated to identify the hydrogeologic interval monitored by each well used in this investigation. This was necessary to ensure that groundwater data used were correctly associated with the position along the respective groundwater flow path from which each sample was taken. 
- Hydrographs (water-level trend plots) and other water-level data were used to delineate areas with rapid groundwater change (e.g., drainage and outflow) from those areas that appear more stable (e.g., less groundwater decline and equilibrium). Water-level information was correlated with the hydrogeology to identify aquifer boundaries, flow barriers, and preferential flow paths.

- Groundwater tritium activity and contaminant concentrations are plotted spatially to delineate groundwater flow patterns and aid in identifying separate aquifer flow zones and their related hydrogeologic units.

- Hydraulic parameters (e.g., aquifer test results) reported by Wurstner et al. (1995) from slug and pumping tests, and results from soil sample analysis, deemed to be valid for estimating hydraulic conductivity were used to identify preferential flow paths and barriers.

- Spatial data were used to geographically correlate surface and subsurface features on maps. These data include information from the Computer-Automated Mapping Information System (CAMIS), the Hanford Geographical Information System (HGIS), and the PNNL Geographical Information System (PNLGIS).

An evaluation of geologic sample descriptions and logs, laboratory analysis, core and drill cuttings, and geophysical logs aid in the accurate correlation of hydrogeologic units from one well to the next. Integration of geophysical data into the geologic data set is a key component in preparation of the revised hydrogeologic interpretation presented in this report. Bjornstad (1984) provided detailed suprabasalt geophysical lithologic correlations in the 200-West Area, but since that time, consistent use of geophysical data has not been part of past regional geologic or hydrologic interpretations and reporting.

Borehole geophysical data were used to aid in correlation of hydrogeologic units between wells. This was particularly helpful in correlating data from wells that have little or no reliable geologic data, particularly older wells in which a driller's log description was often the only other subsurface information available.

Several criteria were used to identify and map Unit 8 (Ringold lower mud). The selected criteria necessary to consistently identify the interval Unit 8 include: 1) a geophysical gross or spectral gamma (and/or potassium-40) signature composed of increased values (above a sand/gravel baseline) in conjunction with available geology; 2) geologist's or driller's log descriptions that must indicate the presence of clay, silt, mud, ash, or other fine-grained sediments; and 3) hydrologic data (could be from driller's logs, neutron logs, and/or aquifer testing and soil sample analysis, etc.) used to determine or confirm a lowpermeability interval from adjacent units. Because of various drilling methods, and the variable emphasis given to formation depth control by the drillers and geologists, the criteria for determining formation depths is weighted most heavily on the geophysical logs, because the geophysical logs provide a continuous curve and allow a more accurate pick for formation tops than do the sporadic and sometimes inconsistent descriptions inherent in driller's and some geologist's logs. In many cases, only the change in formation was noted within a given drilled interval by the driller or geologist but not the depth of the contact between the formations. 
Using these criteria, the Unit 8 is mapped as a hydrogeologic-confining interval (aquitard). This gross interval often contains more than one depositional unit that could include lacustrine, fluvial, and/or pedogenic deposits composed of more than one fine-grained interval such as clay, silt, ash, or sand. The top of the Unit 8 is a straightforward contact to identify; however, the base of this confining unit is more difficult and subjective because of the variability and often gradational nature along the lower boundary.

Drilling information often provides qualitative evidence about the geologic formation encountered. For example, descriptive terms recorded during drilling, such as "loses water," "no cementation," and "no recovery," may indicate a younger, less consolidated or reworked Hanford formation sand and gravel. Terms like "indurated," "cemented," "oxidized," or "clayey" could indicate an older more compacted and cemented material and are often characteristic of Ringold Formation sediments. Hydrologic descriptions, such as "loses water" and "won't hold water" may indicate a relatively permeable formation. Terms like "water shuts off," "clay binders," "drills easy," "hole stays open," and "increasing water level measurements" may indicate units that are relatively lower in permeability or hydraulic conductivity.

\subsubsection{Maps and Cross Sections}

The PNNL's Well Log Library and the PNLGIS were used to prepare structure and isopach maps showing the elevation and thickness of key hydrogeologic units and five cross sections as visual representations of the subsurface hydrogeology and hydrogeology. These five structural cross sections, Lines 1-5, are Plates 9, 10, and 11 and represented schematically in Figures 4.1 through 4.5. These cross sections are oriented either roughly perpendicular or parallel to the regional structural trends and depositional axes of the geologic units (Plate 1). These visual aids are intended to help illustrate the most recent interpretation of the lateral and vertical extent and variability of the principal hydrogeologic units within the geologic framework and their relationship to groundwater movement through the area.

The hydrogeologic nomenclature used in these five cross sections and maps is illustrated in Figure 3.1. Measurements on the cross sections are reported in English units (feet) rather than metric (meter) units because most well logs and driller's records are recorded using the English units as the standard unit of measurement. Surface elevations (reference point) are rounded to the nearest foot and represent recent Hanford well survey results with respect to the North American Vertical Datum of 1988 (NAVD88). Measurements used to create the maps are reported in metric units.

The salient features associated with each of the five cross section lines (see Figure 1.3 and Plate 1) are discussed in the following subsections. Changes from previous work also are discussed and justifications for changes are presented.

\subsubsection{Line 1}

Cross Section 1 (Line 1) (Figure 4.1, Plate 1 and Plate 9) shows the groundwater conceptual model for the suprabasalt aquifer system along the eastern edge of the 200-West study area. The southern portion of Line 1 illustrates the suprabasalt hydrogeolgic sequence near the Cold Creek synclinal 


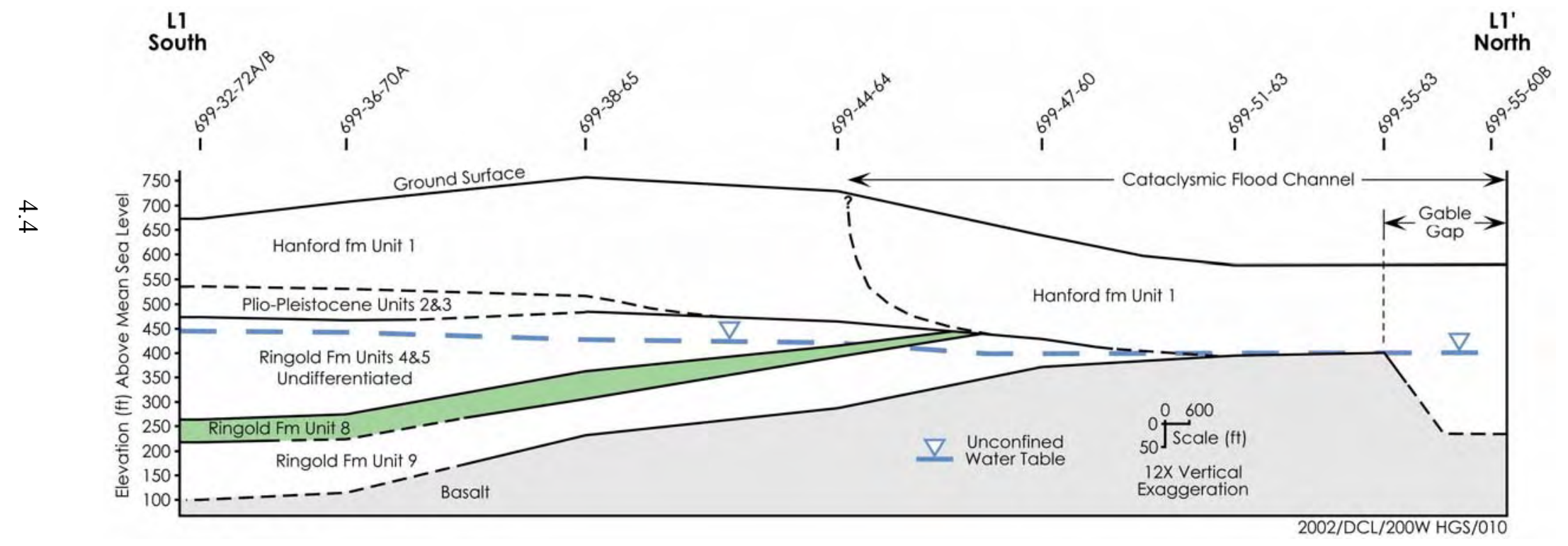

Figure 4.1. Schematic Hydrogeologic Cross Section of Line 1-1' 


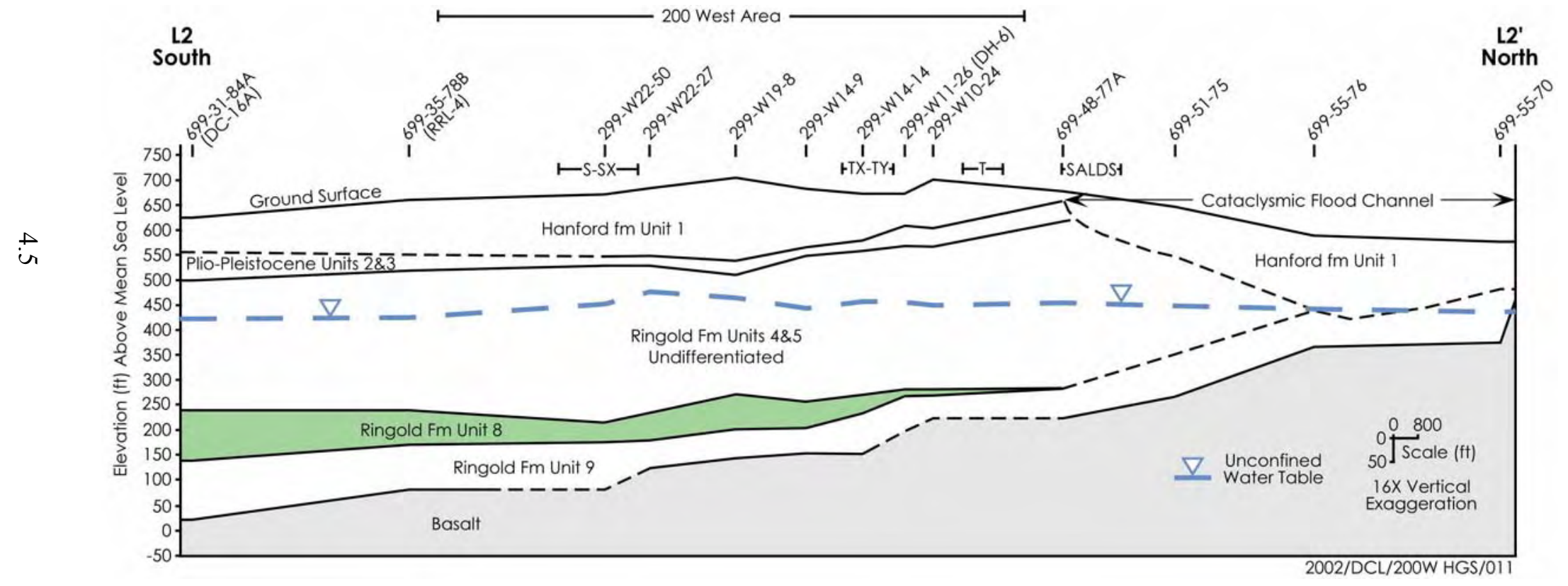

Figure 4.2. Schematic Hydrogeologic Cross Section of Line 2-2' - 200-West Area and Vicinity 


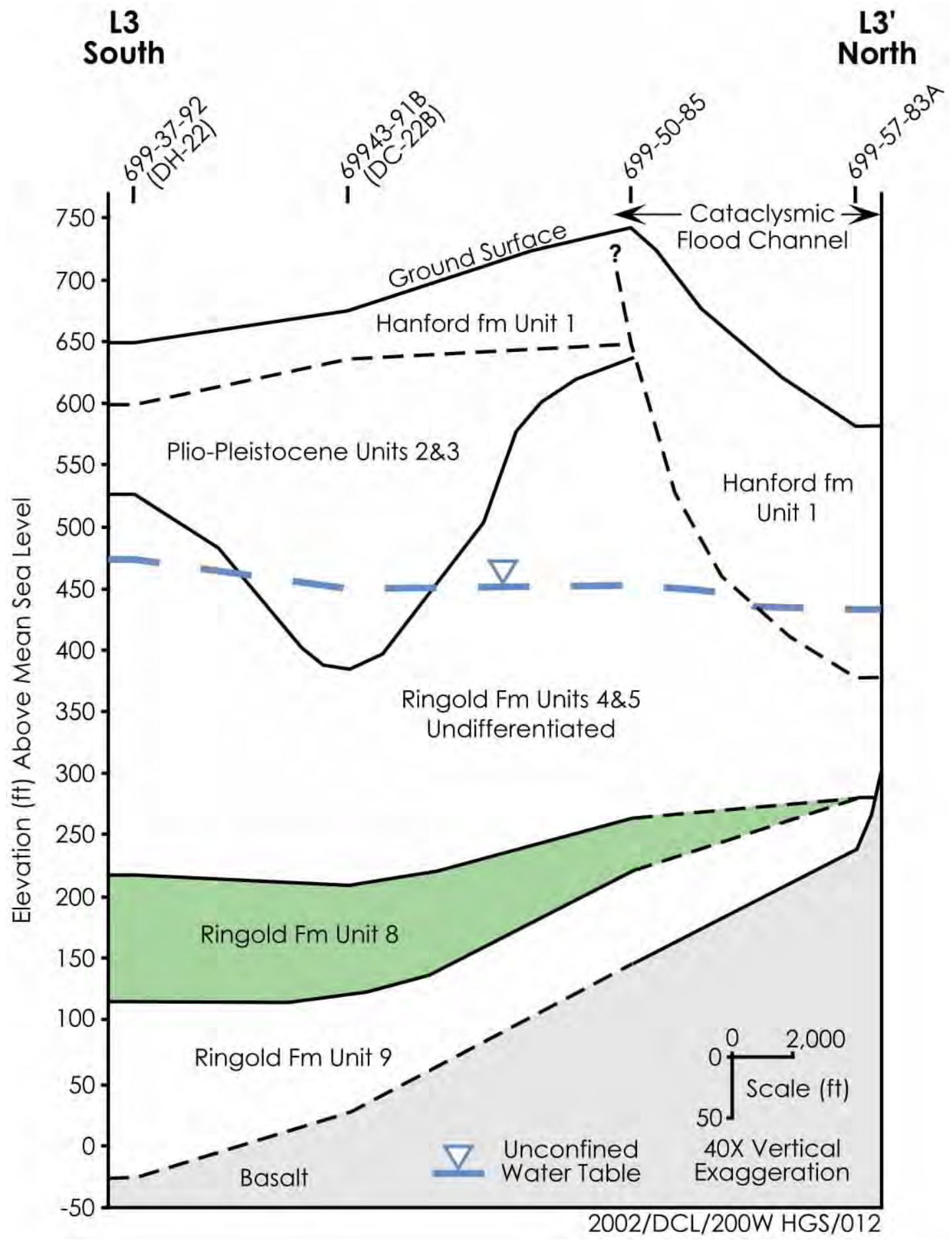

Figure 4.3. Schematic Hydrogeologic Cross Section of Line 3-3' - 200-West Area and Vicinity 


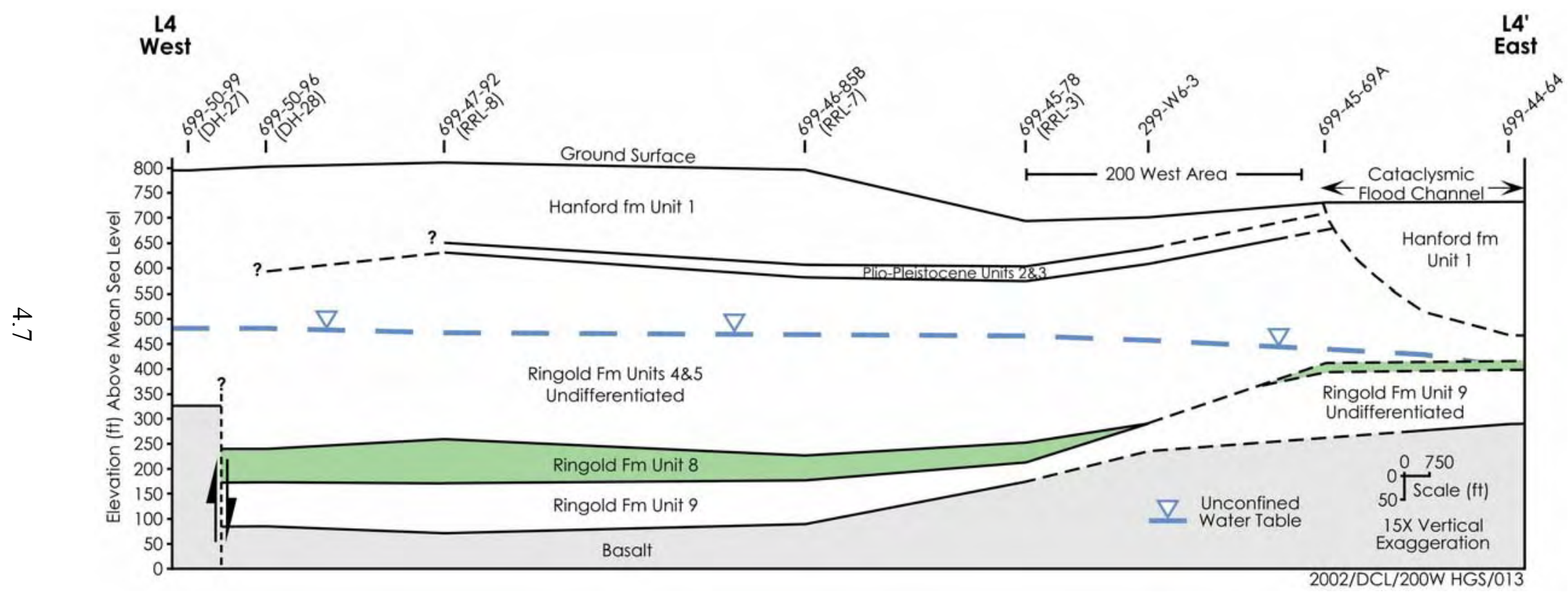

Figure 4.4. Schematic Hydrogeologic Cross Section of Line 4-4' - 200-West Area and Vicinity 


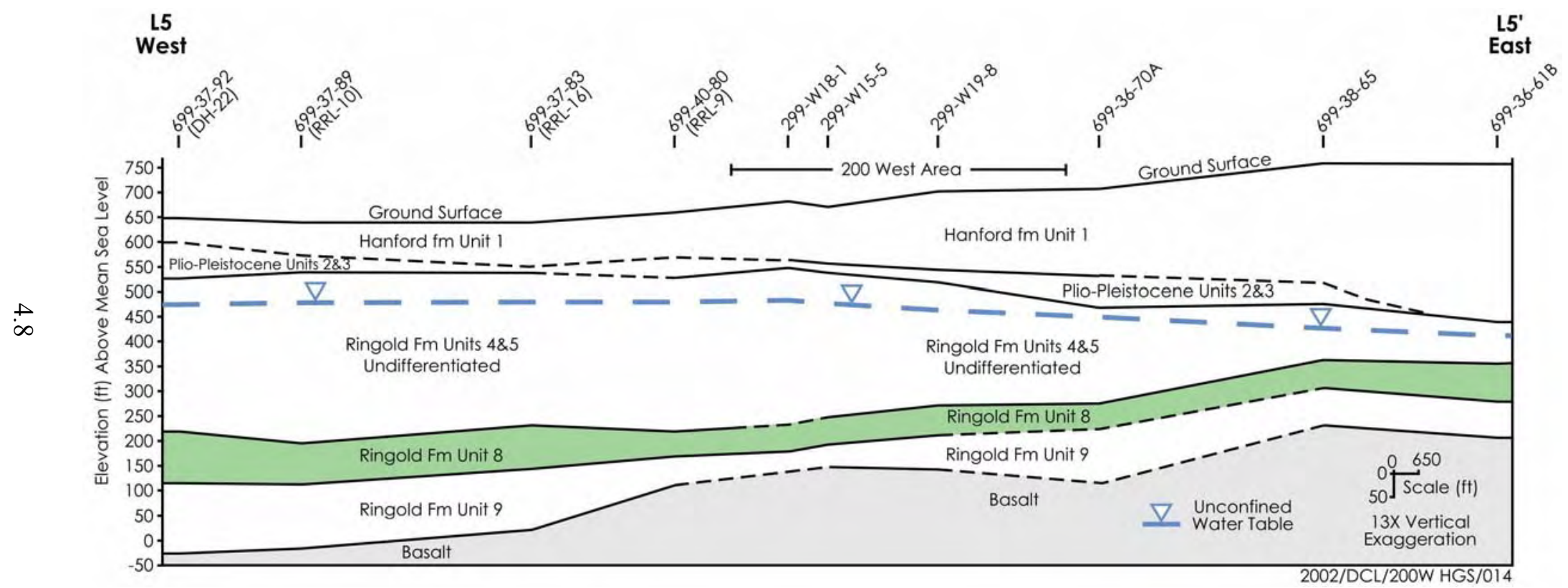

Figure 4.5. Schematic Hydrogeologic Cross Section of Line 5-5' - 200-West Area and Vicinity 
axis just south of the 200-West study area from basalt through Ringold Formation, Plio-Pleistocene, and Hanford formation. The northern portion of Line 1 extends across the anticlinal nose of Gable Butte into the basalt erosional window at Gable Gap.

Line 1 illustrates the hydrogeology roughly perpendicular to the ancestral Columbia River/ Pleistocene cataclysmic flood paths (Figure 4.1, Plate 9). Salient hydrogeologic features include the relative stratigraphic position and thickness of the confining Ringold Unit 8 (lower mud), with respect to the basalt surface; the continuity of Unit 8 up onto the structure; and the northern, structurally elevated, area where Units 8 and 9 have been truncated or removed. The relative position (vertical separation) of these units is maintained up onto the structure, but includes some depositional thinning. This indicates uplift of Gable Butte as well as other Yakima folds was occurring during Ringold time (Reidel and Fecht 1981; Bjornstad 1985). The northern portion of the line illustrates the area of elevated basalt, which is overlain solely with cataclysmic flood gravel (Unit 1). This area is interpreted to have been eroded by either the ancestral Columbia River and/or Pleistocene cataclysmic flooding, which removed the older Ringold Units 5, 8, and 9. This paleochannel/flood path interpretation is consistent with the mapped results that extend into the 200-East Area (Williams et al. 2000).

Uplift of Ringold Formation sediments adjacent to Gable Butte (structural high) and subsequent erosion by ancestral Columbia River/Pleistocene cataclysmic flooding is supported by the presence of a thick sequence of Units 8 and 9 along the southern flank of the Gable Butte anticline, which abruptly disappears at the point where the suprabasalt sediments above the basalt thin rapidly. This thinning is in the area of elevated basalt beneath a topographic low, which is interpreted as a remnant paleochannel. This remnant channel trends northwest to southeast and merges with other paleochannels near Gable Gap and is interpreted to be a channel scour left after the Pleistocene cataclysmic floods (depicted on Plate 1). The northern portion of Line 1 near Gable Butte illustrates that most or all of the Ringold Units 5-9 could have been removed as a result of the relative uplift and subsequent erosion by flooding and/or fluvial incision by the ancestral Columbia River (see also Williams et al. 2000). In this northern portion, the Ringold Unit 8 is not present. The Elephant Mountain Member forms the base of the upper suprabasalt aquifer system (except possibly in the eroded basalt window) as illustrated on Line 1 north of well 699-47-60 (Plate 9).

The uppermost aquifer within the northern erosional area, and south of the basalt window, is interpreted to be within a thin $(<10 \mathrm{~m}[<33 \mathrm{ft}])$ sequence of Hanford formation Unit 1 gravel that was deposited directly on top of the Elephant Mountain Member.

The large erosional channel depicted in the northern portion of Cross Section 1 contains mostly Hanford formation cataclysmic flood deposits. Delineating the basal limit or contact of the channel(s) is difficult in some areas because of the variable (reworked versus in situ), but similar, lithology (i.e., depositional framework). Borehole geophysics, geological and drilling information, and hydrologic results have been used together as corroborative evidence for delineation of this paleochannel. Borehole geophysical logs were also used to illustrate the absence or presence of the Ringold Unit 8 (lower mud) signature (type curve) that can be seen in nearby wells inside and outside the channel, respectively. 
The very north end of Line 1 (well 699-55-60B) reveals an abrupt structural drop in the basalt surface at a location just northeast of the Gable Butte anticlinal high within Gable Gap. The revised top-of-basalt structure map (Plate 2) reveals this as an area that was impacted by strong erosional forces from cataclysmic flooding, which plucked out fractured and weakened basalt allowing deep pockets or holes to be eroded into the basalt surface. This erosion completely removed portions of the Elephant Mountain Member, creating windows through the basalt and intercommunication pathways between the confined basalt interbed aquifers (e.g., Rattlesnake Ridge interbed) and the uppermost suprabasalt aquifers (see Spane and Webber 1995; Graham et al. 1984; Jensen 1987; Vermeul et al. 2001).

In the area between wells 699-44-64 and 699-47-60, the Ringold Unit 8 is interpreted to have been truncated during Pleistocene cataclysmic floods. Older, deeper Ringold Unit 9 sediments continue across this area and probably include subunits 9B and 9C in well 699-47-60. Also of note is the location of the Unit 8 (lower mud) with respect to the top of the aquifer in well 699-44-64. As will be discussed later in this section, the presence of the Unit 8 at or near the water table creates a barrier to groundwater flow from 200-West Area. Plate 5 shows the area where the Ringold Unit 8 is above the water table, creating a potential groundwater flow barrier, i.e., groundwater cannot flow across or through this area. Connelly et al. (1992a) also maps an area similar to this where the Ringold Unit 8 may project above the water table. South and west of well 699-44-64, the Unit 8 dips below the water table of the upper unconfined aquifer, creating a thickening of the uppermost aquifer with distance toward the 200-West Area. The Ringold Unit 8 subcropping at the water table could explain, in part, the steep water-table gradient that is perpetuated upgradient immediately behind this well (Hartman et al. 2000 and Plate 5). The Ringold Unit 8 is probably a contributing factor to the steep water-table gradient, effectively reducing the aquifer thickness and transmissivity and creating a potential bottleneck for groundwater and contaminants emanating from the 200-West Area. Younger, highly conductive Hanford formation sand and gravel to the north and east of this area increases the transmissivity contrast across this juncture, which reduces the gradient.

\subsubsection{Line 2}

Line 2 (Figure 4.2, Plate 1 and Plate 9) is a north-south-oriented hydrogeologic cross section across the central 200-West Area. Line 2 provides the best representation of suprabasalt hydogeology beneath the 200-West Area. This line is oriented roughly perpendicular to a cataclysmic flood channel that cuts through and removed older Ringold-age sediments south of Gable Butte (Figure 1.3).

Several observations are made along Line 2. Basalt and Ringold Units 5, 8, and 9 all dip uniformly to the south beneath the 200-West Area toward the Cold Creek syncline axis. Unit 8 (lower mud), which is nearly $20 \mathrm{~m}(66 \mathrm{ft})$ thick in the south, thins to zero at the north end of the 200 -West Area and is absent in wells 699-48-77A and 699-51-75. This thinning is presumed to be depositional thinning onto structure or onlap deposition (Lindsey et al. 1994), not the result of paleo-erosion seen farther east. The presence of a thick sequence of younger Ringold Formation Unit 5 and the overlying Plio-Pleistocene unit (Units 2 and 3 ) corroborate the depositional thinning model in this location (see well 699-48-77A). Immediately north of this area, the Plio-Pleistocene calcic paleosol facies association (PPUcp) (i.e., caliche) is absent as a result of erosional scouring within a cataclysmic flood channel. At this location along the line, the topography rolls over and plunges to the north until it rises again onto the subaerially exposed basalt that forms Gable Butte. As discussed previously for Line 1, Pleistocene cataclysmic flooding scoured out 
Ringold Units 5 and 9, leaving only the eroded/reworked lower Ringold 9 overlain with very coarsegrained Hanford formation sand and gravel. More information on the creation of the Pleistocene flood channels and possible flood scenarios can be found in DOE (1988), Baker et al. (1991), Williams et al. (2000), and Bjornstad, in press. ${ }^{1}$

At the north end of Line 2, the water table dips to the north and flows from the Ringold Unit 5 gravel into the more permeable Hanford Unit 1 flood gravel due to the absence of Ringold-age sediments at this elevation. Usually, the intersection of the water table and basalt represents the northern limit of the uppermost-unconfined aquifer in the 200-West Area; however, at the north end of Line 2, geophysical and drilling data in well 699-55-70 suggest there is a significant amount of fine-grained sediment in the lower section just above the basalt. Drilling data and well workover results suggest that the aquifer in this area is confined to semi-confined and significantly lower in permeability than wells completed in the Hanford formation gravel farther south (Plate 9). The age (stratigraphic position) of this fine-grained material is not known. This unit is mapped as lower Ringold Unit 9, but it could also be Hanford formation. This well is interpreted to represent the northern limit of the upper most unconfined aquifer because the saturated units in this well are semi-confined and not considered to be effectively in communication with the unconfined aquifer. This interpretation is supported by groundwater measurement data that indicate that the water level in the well did not decline significantly from 1979 through 2001 (Plate 12). Although not shown on Line 2, the basalt surface rises above the regional water table just north of this well (see basalt structure map). The relative change in water-table elevations is illustrated on the cross section and represents changes in water levels from the early 1950s to the mid-1990s. In the late 1980s, the water table was near its maximum height as a result of facility effluent disposal operations.

The unconfined aquifer throughout the southern portion of the 200-West Area lies within the Unit 5 Ringold gravel overlying the Ringold Unit 8. These units all dip south toward the Cold Creek syncline axis. The thickness of the uppermost aquifer ranges from $60 \mathrm{~m}(197 \mathrm{ft})$ near the southern end of the

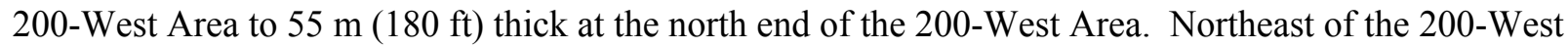
Area, the aquifer reaches its thinnest point, not against the basalt as depicted farther north, but against the uplifted Ringold Unit 8 (lower mud unit) (see aquifer thickness map-Plate 13). Groundwater movement and plume migration paths may be impacted by this thinning of the aquifer. This effect is illustrated on the regional water-table map by the divergence in flow direction between plumes that emanate from the northern portion of the 200-West Area and plumes that emanate from the southern portion of the 200-West Area (Plate 14). Superimposing the water-table map with the existing regional plumes and the up-dip limit of the Ringold Unit 8 (Plate 15) reveals that the thinning aquifer is created by changes in geologic units saturated at/near the water table, which influence the groundwater travel path and flow rate for contaminants migrating out of 200 -West Area. The two primary contaminant flow paths out of 200-West Area are well established; however, the hydeogeologic framework or the hydrstratigraphic controls which determine the particular pathway groundwater follows has not been clearly defined.

\footnotetext{
${ }^{1}$ Bjornstad, B. N., G. V., Last, G. A. Smith, K.A. Lindsey, K. R. Fecht, S. P. Reidel, D. B. Horton, and B. A. Williams. Draft 2001. Proposed Standardized Stratigraphic Nomenclature for Post-Ringold-Age Sedimentary Deposits Within the Central Pasco Basin. White Paper Proposal, Pacific Northwest National Laboratory, Richland, Washington.
} 
Additional wells located within these two primary preferential flow paths would provide key strategic locations to monitor contaminant plumes migrating from the 200-West Area into the 200-East Area, and possibly north through Gable Gap.

Also illustrated on Line 2 (Plate 9) are three recently installed RCRA wells from which deep multidepth groundwater sample data has been collected. Vertically discrete water samples were collected from sampling points above and below the Ringold Unit 8 (lower mud) in these wells which span the 200-West Area. Groundwater data from these wells have provided the most recent and compelling groundwater chemistry profiles from intervals deep ( $>10 \mathrm{~m}[>33 \mathrm{ft}]$ ) in the unconfined aquifer (Johnson and Horton 2000; Hodges and Horton 1999a, 1999b). Results from the aquifer samples are reported in Johnson et al. (2001). The results indicate that contaminants have migrated deeper in the unconfined aquifer than previously recognized. Data also suggest that contamination (carbon tetrachloride) is present in Unit 9, the confined Ringold aquifer below the Unit 8 confining layer, at elevated concentrations. More discussion on the aquifer hydrochemistry and vertical contaminant distributions follows in Section 4.3.

\subsubsection{Line 3}

Line 3 (Figure 4.3, Plate 1 and Plate 10) is a south-to-north-oriented structural section located west of the 200-West Area that extends from the central axis of the Cold Creek syncline north onto the south flank of the Gable Butte anticline. This section is roughly perpendicular to the structural and depositional axis of the ancestral Pleistocene cataclysmic flood path that influenced the area and illustrates the depositional and structural position of Ringold Units 5, 8, and 9 within the suprabasalt aquifer system.

The suprabasalt stratigraphic section is thickest in the south, thinning to the north onto the rising basalt structure. Geophysical logs were used to correlate and map the Ringold Unit 8 north to well 699-50-85. North of 699-50-85, Ringold Unit 8 pinches out or has changed facies, grading into a sandier interval. The absence of the high gamma activity on the geophysical log from well 699-57-83A illustrates this change.

Near the southern end of Line 3, the contact with the top of the Ringold Unit 5 in well 699-43-91B is structurally lower and overall thinner than surrounding wells. It is overlain by coarse, very basaltic, angular, sandy gravel to gravel that is only identified in surrounding, structurally low-lying boreholes (see also Ringold Unit 5 structure map). This gravelly unit represents the sidestream alluvial facies of the Plio-Pleistocene unit, deposited within a northwest-southeast trending ancestral Cold Creek channel (Bjornstad 1984; DOE 1988).

With the exception of the sidestream alluvial facies identified in well 699-43-91B, an upper Ringold unit (Unit 4) sand to silty sand overlies the Ringold Unit 5 in this area. Unit 3 overlies the Ringold units in the southern portion of the section but is absent in well 699-57-83A, eroded out by cataclysmic flooding. The flood channel that eroded the Plio-Pleistocene Unit is at about the same place as the present-day channel. As discussed in Williams et al. (2000), the topography provides a telltale indicator of where large-scale Pleistocene erosional flood events occurred. The absence of the Plio-Pleistocene unit and upper Ringold sediments support this interpretation. The boundary of this large channel is interpreted to be between wells 699-50-85 and 699-57-83A. 
On Line 3, the water table is highest in the south, and the upper most unconfined aquifer flows north in this region (Plate 14). In the north, the upper unconfined aquifer is interpreted to flow from the Ringold Unit 5 into the younger Hanford formation Unit 1 sediments deposited within the cataclysmic flood channel at this location.

\subsubsection{Line 4}

Line 4 (Figure 4.4, Plate 1 and Plate 11) extends from the western boundary of the study area eastward across the Cold Creek fault and the northern portion of the 200-West Area ending at the 200-East Area study boundary (Figure 1.2). The west end of Line 4 includes two wells that bound the

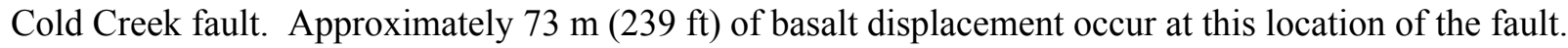
Well 699-50-96, located on the downthrown side of the fault, contains the thickest suprabasalt sequence ( $\sim 220 \mathrm{~m}[\sim 722 \mathrm{ft}]$ ) on Line 4. The base of the suprabasalt aquifer on the upthrown side in well 699-50-99 is older Pomona Member basalt rather than Elephant Mountain Member basalt found most everywhere else in the study area (DOE 1988). The absence of the Elephant Mountain Member basalt and approximately $80 \mathrm{~m}(262 \mathrm{ft}$ ) of relief on top of the Pomona and less than $5 \mathrm{~m}(16 \mathrm{ft}$ ) of Units 8 and 9 (about $27 \mathrm{~m}$ [89 ft] relief on top of Unit 8) indicates that faulting was active through Unit 8 and perhaps into Unit 5 time.

The Ringold Unit 8 is considered to be the most significant hydrogeologic confining unit beneath the 200-West Area. To the east, Unit 8 appears to lap up onto higher basalt surfaces. The boreholes in this section illustrate the relative continuity and stratigraphic position of Unit 8, greater than $70 \mathrm{~m}(230 \mathrm{ft})$ below the water table to the west of the 200-West Area and rising to a point at or above the water table just east of the 200-West Area. At the east end of Line 4, geophysical comparisons and old drilling log descriptions from wells 699-45-69A and 699-44-64 indicate that the Ringold Unit 8 (lower mud) is situated at an elevation that was once at or above the water table. This suggests that groundwater flowing east from the 200-West Area within the overlying Ringold Unit 5 would reach this area and hypothetically be slowed significantly behind this subcropping Unit 8 (aquitard) or possibly diverted north or south of this area flowing much faster around the area where Unit 8 subcrops above/near the water table. The overall aquifer thickness decreases significantly in this area because the Ringold Units 5,8 , and 9 rise in elevation with the basalt structure (Plate 13) effectively reducing the saturated suprabasalt interval. The structure contour map of the Unit 8 (lower mud) (Plate 5) depicts a revised structural surface and proposed limits of the Unit 8. Cross Sections 1 and 4 illustrate the structural position of Unit 8 above the water table northeast of the 200-West Area. It is recommended that additional subsurface data be collected to confirm this interpretation, either through borehole drilling and sample collection or aquifer testing because the validity and quality of the existing well data are limited, and other interpretations have been made, and discrepancies are apparent. Geophysical results and driller's log comments suggest that Unit 8 does or was at one time above the water table. Results from Connelly et al. (1992b) also indicate that the lower mud may be above the water table in this area.

Also of note is the absence of the Unit 2 (PPU oe) and Unit 3 (PPU cp) and most of the Ringold Unit 5 at the extreme east end of the line in well 699-44-64. Well 699-44-64 defines the southern limit of the cataclysmic flood channel scour on Line 4 (Figure 4.4 and Plate 11). Within the 200-East study area, located just east off of Line 4, the Ringold Units 5 and 8 (lower mud) may have been scoured out by the ancestral Columbia River prior to, and in addition to, cataclysmic flooding (Fecht et al. 1987). The upper 
unconfined aquifer exists within the Hanford formation Unit 1 sediments deposited within the paleochannel. Here, contaminants in groundwater move relatively rapidly through the highly conductive, but very thin, unconfined aquifer system beneath the 200-East Area (Williams et al. 2000).

\subsubsection{Line 5}

Line 5 is a west to east cross section that parallels Line 4 and runs through a deeper portion of the Pasco Basin, the Cold Creek depression (DOE 1988), near the Cold Creek synclinal axis, and through the southern portion of the 200-West Area, east to the 200-East study area boundary (Figure 4.5, Plate 1, and Plate 11). Most notable features are the continuity of the Ringold Unit 8 aquatard, the decrease in the thickness of the Ringold Unit 5 at the east end, and the thinning of the upper aquifer toward the east.

The units in this line are structurally deeper than those in Line 4 due to its position farther down the flank of the Cold Creek syncline. Unlike Line 4, the Ringold Unit 8 does not rise above the water table but does effectively reduce the uppermost aquifer from approximately $80 \mathrm{~m}(262 \mathrm{ft})$ thick just west of the 200-West Area to approximately $15 \mathrm{~m}$ (49 ft) thick east of the area.

One difference in this revision from previous investigators (Lindsey 1995) is the structure map of the Ringold Unit 8. For example, the depth of the Ringold Unit 8 is reported at approximately $83 \mathrm{~m}(272 \mathrm{ft}$ )

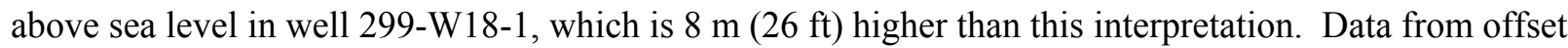
deep wells on Line 5 reveal that the previously interpreted depth does not appear to be the depth of the top of Ringold Unit 8, but rather a shallower sandy silt unit. The well (299-W18-1) was not drilled deep enough to encounter the Unit 8 as evidenced by offsetting wells east and west of this location. Additional work needs to be done to define and map this upper fine-grained unit; as the correlations in this report indicate, it is present in some of the deeper western portions of the study area and may create locally deep confining conditions above Ringold Unit 8.

Line 5 illustrates the uppermost-unconfined aquifer that is contained within the Ringold Unit 5 (Ringold Unit E) sandy gravel. This thick unit is quite heterogeneous and exhibits variable groundwater flow conditions. The Ringold Unit 5 is mapped as a single hydrogeologic unit because data are not available to subdivide the unit into more discrete flow/no-flow subunits. A structure isopach map of the top of Ringold Unit 5 is presented in Plate 7.

Confined groundwater occurs below Ringold Unit 8 in the suprabasalt sediments of Ringold Unit 9. This confined aquifer is composed of Unit 9 where it occurs below the Unit 8 mud and is referred to as the confined Ringold aquifer system.

\subsubsection{Observations}

This study supports findings of Williams et al. (2000), which proposed two distinct aquifer systems in the suprabasalt sediments. The Ringold Unit 8 (lower mud) separates these aquifers except in the northern and northeastern parts of the 200-West Area where Unit 8 is missing. Post-Ringold fluvial and cataclysmic flood-related erosion appears to have removed and/or reworked the Ringold-age sediments from much of the area north of the 200-West Area and east across the northern 200-East Area. The north 
end of Lines 1, 2, and 3 is approximately perpendicular to the paleo-flow path of cataclysmic flooding and illustrates the pattern and extent of channel development into the older Ringold units (Units 5, 8, and 9). Within these areas, most of the Ringold is eroded and has been replaced with younger highly permeable gravel and sand of post-Ringold Plio-Pleistocene age.

At various locations along this erosional boundary, the unconfined aquifer flows northeast to east from the less permeable Ringold Unit 5 (and presumably Unit 9) into the younger and more permeable Hanford formation Unit 1 sand and gravel.

The location of the buried cataclysmic flood paleochannel in the subsurface is roughly coincident with the last flood channel, which is expressed topographically in Figure 4.6 (Plate 1). Throughout most of the 200-West Area, the unconfined aquifer is relatively thick, ranging from 70 to $20 \mathrm{~m}$ (230 to $66 \mathrm{ft}$ ), and averaging over $40 \mathrm{~m}(131 \mathrm{ft}$ ) thick (Plate 13). Historical and present-day groundwater-table maps indicate that contaminants emanating from the 200-West Area will migrate eastward toward the erosional boundary along two separate flow paths, one to the northeast and one to the east (Hartman et al. 2001). This groundwater flow divide in the groundwater contaminant flow path maybe partially explained by the presence of the Ringold Unit 8 (lower mud) at or near the water-table in the area just northeast of the 200-West Area. This relationship is illustrated in the revised structural map of the Unit 8 (Plate 5). As contaminants within the upper unconfined aquifer move east they must move through a region of high gradient where the aquifer thins quickly and becomes constrained by the older Ringold units, primarily the Ringold Unit 8 confining unit, which is located at the base of the aquifer.

\subsection{Groundwater Flow Patterns}

The uppermost suprabasalt aquifer beneath the 200-West Area is unconfined (uppermost-unconfined aquifer) and consists primarily of Unit 5 (Ringold Formation Unit E) and locally Units 1-3 (Hanford formation) sediments. The uppermost-unconfined aquifer flows generally east toward the 200-East Area where it flows into the Hanford formation Unit 1 sediments along a paleochannel erosional boundary. This upper unconfined aquifer has often been referred to as the Hanford unconfined aquifer.

Northeast and east of the 200-West Area where Units 5 (Ringold Unit E gravel) and 8 (Ringold lower mud unit) sediments have been removed by erosion, the upper unconfined aquifer also may include some reworked and/or intact Unit 9 (Ringold Formation Unit A) sediments. In most areas of the Hanford Site, Unit 8 underlies the uppermost-unconfined aquifer, separating and isolating it (hydraulically distinct) from the older underlying Unit 9 (Ringold Formation Unit A) suprabasalt sediments. Where Unit 9 sediments are isolated from the uppermost-unconfined aquifer by Unit 8, they form an independent suprabasalt aquifer system that has been called the confined Ringold aquifer.

Plate 14 illustrates the revised water-table map for the uppermost-unconfined aquifer. A semi-radial flow pattern east and north from the 200-West Area persists due, in part, to the influence of past-practice liquid effluent disposal and development of the groundwater recharge mound within the area. 


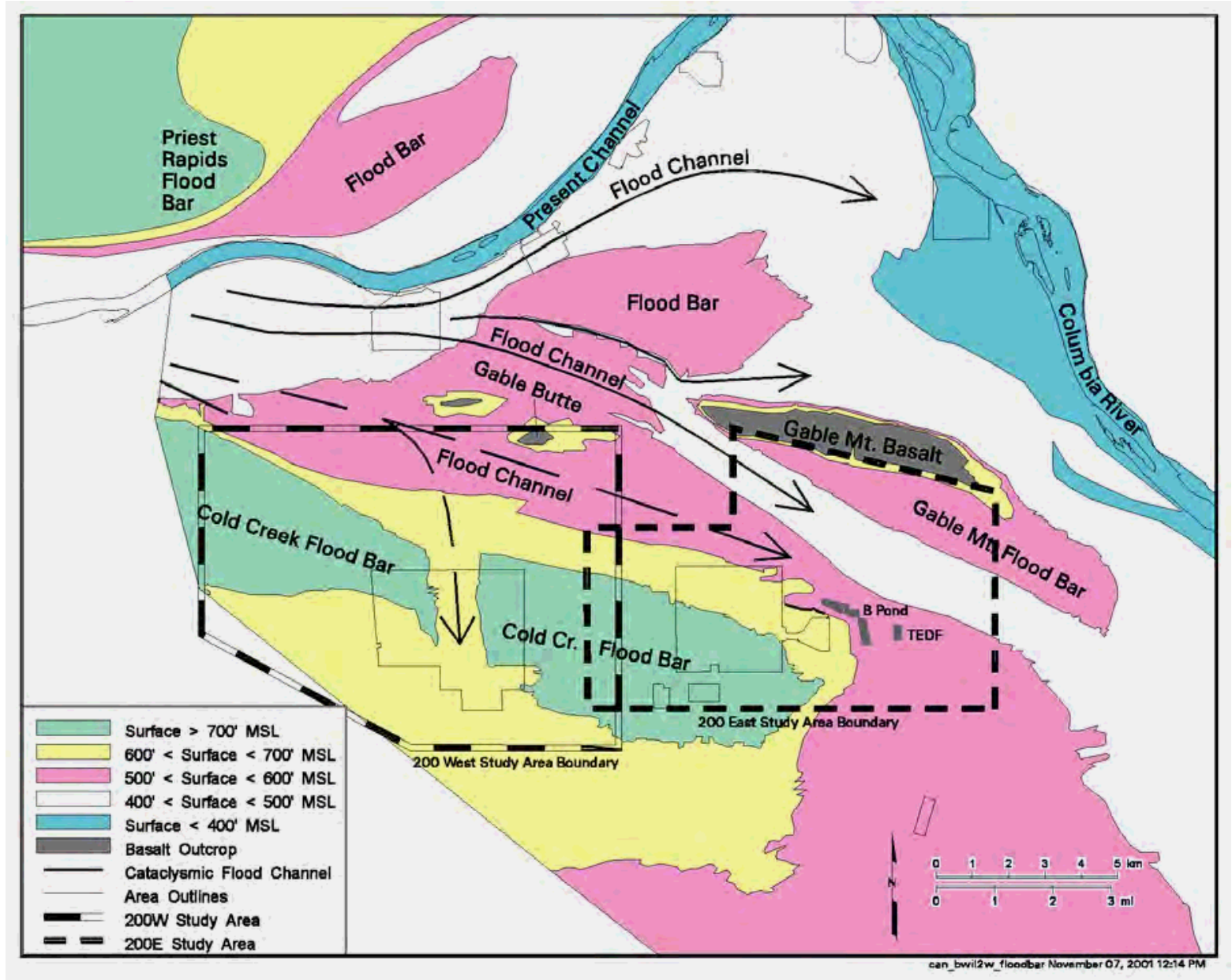

Figure 4.6. Topographic Illustration of Pleistocene Flood Channels and the Present-Day Columbia River Channel Pathways, with Outlines of the 200-West and East Study Areas, Hanford Site, Washington

Within the 200-West study area, just east and northeast of well 699-44-64P (Plate 1), a significant change in groundwater flow conditions occurs across a channel boundary due to a significant change in aquifer conditions which creates the large gradient across this boundary. A groundwater flow barrier is created by a reduction in the aquifer thickness where the Ringold Unit 8 aquitard projects above the water table.

This study suggests that the Unit 8 confining unit east of the 200-West Area is at an elevation at/near the present-day water table. This area of the unconfined aquifer is very thin $(<10 \mathrm{~m}[<33 \mathrm{ft}])$, relatively tight, and thus forms a considerable flow constriction or barrier. This physical impedance to groundwater flow is illustrated in Plate 13 and the steep hydraulic gradient is shown on Plate 14. Note the relationship between the water-table gradient and the Unit 8 structure. Also affecting this gradient is the fact that north and east of this area of constricted flow the aquifer permeability increases by several orders of magnitude, thus causing the water table to drop considerably on the northeast and east side of this flow constriction. 
The reduction in aquifer thickness (i.e., hydrogeologic Unit 5) due to the presence of the Ringold Unit 8 at or near the water table in this area is a major contributing factor to the steep gradient that persists. The dramatic change in gradient results from the low hydraulic transmissivity of the Ringold Units 5 and 9 relative to the high transmissivity of Unit 1 (Hanford formation), which comprises the uppermost-unconfined aquifer within the paleochannel (Bryce et al. 1991).

Wells in the 200-West study area were evaluated and categorized based on the hydrogeologic unit within which they were completed (Appendix C). Revised water-table and aquifer thickness maps (Plates 13 and 14) are presented that recognize Unit 8 as the primary suprabasalt flow boundary for groundwater and contaminants migrating east out of 200-West Area. Groundwater within Units 1-5 (except Unit 2) is categorized as part of the uppermost-unconfined aquifer. Groundwater within and below Unit 8 is categorized as the confined Ringold aquifer system. The water table for the uppermostunconfined aquifer is illustrated in Plate 14.

\subsubsection{Recharge}

Previous liquid waste disposal practices at 216-U-10 Pond (U Pond), and other facilities established localized water-table mounds that elevated the water table throughout the 200-West Area. Effluent discharge and subsequent groundwater mounding beneath U Pond and other disposal sites has resulted in more than $25 \mathrm{~m}$ (82 ft) of increase in the water table during the peak discharge period (1965-1985) (Johnson et al. 2001; Last et al. 1994). Locally, this resulted in a downward vertical gradient and a radial flow pattern that is moving groundwater contaminants from the 200-West Area east and northeast toward the Columbia River. This observation was reported in Graham et al. (1981). Maximum and minimum water-table fluctuations are illustrated on Lines 1-5 where water level data are available.

These past-practice disposal episodes created a downward vertical head in the uppermost aquifer, which has created a net downward force, driving contaminants deeper within the Unit 5 unconfined aquifer (Johnson et al. 2001). As groundwater migrates to the north and east, moving contaminants through the Ringold Unit 5 gravel, it will eventually encounter the more permeable Unit 1 sand and gravel, which is juxtaposed along the erosional boundary just north of 200-West Area and west of the 200-East Area. Once into the Unit 1, the groundwater pathway is via one of two primary flow paths: north through Gable Gap or across 200-East (see Williams et al. 2000).

Liquid effluent discharges to the 200-West Area began to decrease in the late-1980s. The DOE required that the use of soil columns to treat and retain suspended or dissolved contaminants from liquid waste streams be discontinued (DOE/RL 1987). The Tri-Party Agreement (TPA) milestone M-17-00A defined the schedule to discontinue disposal of contaminated liquids into the soil column and cease all non-permitted liquid discharges to hazardous waste land disposal units (ponds, cribs, and ditches) at the Hanford Site by 1995 (Ecology et al. 1998). By 1997, all discharge to the 200-West Area disposal facilities had ceased with the exception of the State Approved Land Disposal Site (SALDS). Concurrent with the decreased wastewater discharge in the 200-West Area, the water table has declined. The decline had occurred at an increased rate since about 1996 and has just begun to decrease in the past few years. The net decline in the water table within the study area from 1979 through 2001 is shown in Plate 12. 
The last remaining effluent disposal site, SALDS, is located north of 200-West Area where the Unit 8 (Ringold Formation lower mud unit) is absent, and the uppermost-unconfined aquifer flows within the Ringold Unit 5. Recent hydrochemistry indicates that wastewater discharge to the SALDS does not significantly impact water quality of the uppermost-unconfined aquifer within the 200-West Area (Barnett 2000), but downgradient wells have increased heads and have detected increases in tritium associated with the SALDS wastewater disposal.

\subsubsection{Groundwater Flow in the Hanford Unconfined Aquifer}

Regional groundwater flow in the Central Plateau is generally from the 200-West Area toward the 200-East Area and the Columbia River (Hartman et al. 2001). Groundwater within the uppermostunconfined aquifer from the 200-West Area flows through Unit 5 sediments, which are juxtaposed to Unit 1 (Hanford formation) sediments in the erosional channel(s) north of the 200-West Area and near the 200-East Area. Groundwater from the 200-West Area migrates with recharge water disposed in the 200-East Area (e.g., BP-5, PUREX cribs, and B Pond) along a broad, sparsely monitored northwestsoutheast trending area near 200 East at the margins of a buried paleochannel.

In the vicinity of the 200-East Area, groundwater in the uppermost-unconfined aquifer mainly flows in the Unit 1 (Hanford formation) within the buried paleochannel. This groundwater flows either northwest through the Gable Gap or southeast through the corridor of saturated Units 1, 3 and/or 5 southeast of B Pond.

The revised water-table map prepared for the uppermost-unconfined aquifer used only selected wells screened above the Unit 8 or basalt (where Unit 8 is absent), i.e., within the Unit 1 (Hanford formation) and Ringold Unit 5 unconfined aquifer (Plate 14). Units 8 and basalt are considered no-flow zones where they are above the water table. Occurrence of these units above the water table defines the flow boundary for the uppermost-unconfined aquifer. To the south and southwest, Unit 8 (Ringold Formation lower mud unit) dips toward the Cold Creek syncline and is too far below the water table to constrain movement of groundwater in the uppermost-unconfined aquifer. To the east, Unit 8 is structurally at or near the water table, creating an aquifer flow constriction, which contributes to the steep gradient and may exert strong control on contaminant flow out of the 200-West Area.

Groundwater within the 200-West study area can leave the area in three general directions: to the northwest, northeast, and east (Plate 14). Hartman et al. (2001) indicates that contaminants follow the easterly flow paths, that will result in a direct pathway into the 200-East Area preferential flow paths toward the river. Discussion in this report will focus on these two easterly flow paths. One appears to control contaminants in groundwater moving northeasterly out of 200-West Area and the other moving east to southeasterly out of the 200-West Area. Groundwater moves through the Ringold Unit 5 until it reaches higher permeability sediments at the boundary within the northern paleochannel and moves into the Hanford Unit 1 near 200-East Area and north (Plate 14).

In the northeast portion of the study area, groundwater flows through the uppermost-unconfined aquifer within the Unit 1 (Hanford formation) sediments near Gable Gap. It is presumed that the 
hydraulic contrast between Unit 1 and Units 5 and 9 in the upper unconfined aquifer results in flow along a preferential path in Unit 1 (Hanford formation) toward the northeast. This interpretation is reinforced by historical groundwater plume maps and water-table maps (DOE/RL 1995, 1996). Within the uppermost-unconfined aquifer, groundwater flow is also directed by the steep water-table gradient west of the geologic boundary (Units 5, 8, and 1 interface) where the gradient flattens as groundwater flows from Unit 5 (Ringold Formation) into the more permeable Unit 1 (Hanford formation) (Plate 15).

Groundwater from the southern portion of the 200-West Area flows more eastward toward the 200-East Area (Plate 14). Data presented in this report suggest that the flow direction is controlled by the resulting declining water table and the subsequent reduction in thickness of the uppermost aquifer northeast of the this flow path. This restriction creates a groundwater flow barrier that diverts groundwater to the south or east depending on the origin of the groundwater. This interpretation is supported by contaminant plume paths that emanate from this region (Hartman et al. 2001).

Historically, groundwater leaving the 200-West Area has followed the preferential flow path along buried paleochannel(s) north to northwest through Gable Gap or southeast across the 200-East Area. However, the direction of groundwater flow may be changing in response to recent water level declines. The unconfined aquifer along the northern flow path is the thinnest in the study area $(<10 \mathrm{~m}[<33 \mathrm{ft}])$ and may be cut off as the water table continues to decline because more Ringold Unit 8 and basalt will be exposed above the water table. If this occurs, it would create a natural flow barrier restricting the migration of contaminants north toward the 100 Areas. This could result in a longer flow path forcing all groundwater to flow to the south and east across the 200-East Area.

\subsubsection{Groundwater Flow in the Confined Ringold Aquifer}

Regionally, groundwater in the confined Ringold aquifer flows from west to east similar to groundwater in the uppermost-unconfined aquifer (Hartman et al. 2001). Near the 200-West Area, it is more difficult to determine flow direction because there are currently no wells completed within the confined Ringold aquifer. Limited data are available below the confining Unit 8 for the 200 -West Area; however, groundwater heads measured in several deep/shallow well pairs, and deep wells drilled into the Ringold Unit 9 confined aquifer (e.g., Johnson and Horton 2000) indicate a downward vertical hydraulic gradient beneath the 200-West Area from the unconfined Unit 5 into the confined Unit 9.

Groundwater in the confined Ringold aquifer is interpreted to flow laterally through Unit 9 gravel into the juxtaposed uppermost-unconfined aquifer along the buried paleochannel margins. Due to the thickness and relatively low vertical hydraulic conductivity of the overlying confining Unit 8, a lateral flow path within the Unit 9 is the path of least resistance over a vertical flow path.

The probable flow path for groundwater in the confined Ringold aquifer (Unit 9A/C) is into the uppermost-unconfined aquifer east of 200-West Area. As discussed in Williams et al. (2000), the erosional boundary of the Units 8 and 9 may be exposed to the uppermost aquifer along the channel juncture where the Units 8 and 5 has been eroded from above the Unit 9. 


\subsubsection{Intercommunication of Suprabasalt Aquifers}

Throughout most of the Hanford Site, groundwater in the uppermost-unconfined aquifer is isolated from groundwater in the confined Ringold aquifer system by Unit 8 (Ringold lower mud unit). However, an erosional window exists along the margins of the buried paleochannel in the northeast portion of the study area; the confined Ringold aquifer is in direct contact with the Unit 1 (Hanford formation) of the uppermost-unconfined aquifer (Plates 9-11 and Figures 4.1-4.3). Because the hydraulic conductivity of the channel fill is generally much higher than for Unit 9, and assuming that Units 8 and 9 terminate at/near the channel boundary and exhibit an upward gradient in this region, groundwater from the confined Ringold aquifer likely discharges into the highly transmissive channel-fill sediments where it mixes with groundwater of the uppermost-unconfined aquifer. This juncture, in effect, creates a vertical preferential flow path for groundwater in the confined Ringold aquifer (Unit 9) into the adjacent uppermost unconfined aquifer near the 200-East Area boundary where it could be transported toward the river through the uppermost unconfined aquifer.

This hydrogeologic boundary between the Ringold Unit 9 and the overlying Unit 1 (Hanford formation) is relatively broad and flat, and allows confined Ringold aquifer groundwater from the 200-West Area to mix with groundwater within the uppermost-unconfined aquifer within the paleochannel over a wide area. This interpretation is based on an identical process that occurs in the uppermost-unconfined aquifer above the Unit 8 (Figure 4.3, Plate 10) sediments. In the uppermost-unconfined aquifer, contaminated groundwater emanates from the 200-West Area within Ringold Unit 5 and flows into the juxtaposed Unit 1 (Hanford formation) along portions of the erosional channel boundary. This transition zone occurs in the area of steep water-table gradient between the 200-West and 200-East Areas (Plate 14).

\subsection{Groundwater Chemistry}

The primary factors contributing to the distribution of groundwater chemistry, including contamination associated with operations, are the hydrogeologic framework and groundwater flow patterns. The distribution of contaminant plumes corroborates the interpretation of groundwater flow described in previous sections. Because groundwater flow in the uppermost-unconfined aquifer is isolated from flow in the confined Ringold aquifer (except within the erosional unconformity), the distribution of groundwater chemistry and contaminants must be evaluated for each aquifer system independently. However, there are currently no wells completed within the Ringold confined aquifer beneath the 200-West Area for this comparison. For this reason, chemical comparisons between suprabasalt aquifers (i.e., Stiff diagrams [Stiff 1951]) are not possible, and instead, the chemical/contaminant concentrations from wells and boreholes within the uppermost-unconfined aquifer will be used to illustrate the correlations of groundwater and contaminant flow paths. The uppermost-unconfined aquifer is primarily within Unit 5 and the focus of this report will be on the vertical variation of flow and contaminant distributions within this aquifer, which could account for significant differences in contaminant flow rate and paths. 


\subsubsection{Uppermost-Unconfined Aquifer}

Regional groundwater contaminant plumes, water-table elevations, groundwater flow paths, and hydrogeologic units relative to the water table are shown for the uppermost-unconfined aquifer in Plate 15. Generally, most plumes emanating from the 200-West Area can be correlated to past practices at disposal facilities (Hartman et al. 2001) within the area. Two major plume paths can be identified in the uppermost-unconfined aquifer within the study area. These plume paths extend northeast and east away from the 200-West Area. These plume paths correspond to the radial groundwater flow pattern and specific source area locations of contaminants within the 200-West Area that exist within the hydrogeologic framework described in Section 4.1. Data used to evaluate these plume paths are interpreted from shallow ( $<10 \mathrm{~m}[<33 \mathrm{ft}])$ "top of the aquifer" monitoring wells. The uppermost aquifer is over $40 \mathrm{~m}$ (131 ft) thick beneath most of the 200-West Area and as discussed in Section 4.3.1.1, contaminants exist at depths below these monitoring systems that are currently uncharacterized and whose fate is unknown.

The most prominent plume path is located in the southeastern portion of the study area where groundwater in the uppermost-unconfined aquifer flows primarily in Unit 5 (Ringold Formation Unit E) from the 200-West Area toward the paleochannel unconformity near the 200-East Area. Groundwater flowing along this pathway travels unconstrained downgradient from the 200-West source areas. Similar contaminants from several local source areas (i.e., tritium, nitrate, iodine-129) have commingled downgradient of the 200-West Area to form the large plumes that are moving generally eastward. Groundwater plume maps for FY 2000 (Hartman et al. 2001) indicate that these contaminant plumes, flowing through the uppermost-unconfined aquifer, are encroaching on the buried paleochannel. Currently, there are no monitoring wells near this boundary to evaluate the fate of these contaminants as they move into the more permeable channel fill sediments (i.e., Hanford formation Unit 1).

The second plume path appears to originate from source areas within the northern half of the 200-West Area. Contaminants within this area are being transported northeasterly toward the channel boundary along a separate flow path as illustrated in Plate 15 (see also Hartman et al. 2001). The northern component of flow in these plumes suggests that the gradient is more northerly in this area than has previously been mapped. The revised water-table map (Plate 14) includes the interpreted no flow barrier created by the Ringold Unit 8 at/near the water table just east of the northern plume path and illustrates how this barrier and the revised hydrogeology can have a controlling influence on groundwater and contaminant flow in this area.

Along both flow paths contaminant plumes do not appear to extend into the paleochannel, i.e., Hanford Unit 1; however, monitoring well control points are very limited and consist of older wells. These wells were installed years ago, before a complete understanding of the aquifer hydostratigraphy was available. Based on the new hydrogeologic interpretation presented here, these older wells are not necessarily situated in the most strategic location for detecting and or intercepting migrating contaminants from the 200-West Area. At specific locations within the paleochannel, the direction of groundwater flow is uncertain and has likely changed over time in response to changing wastewater discharge practices within both the 200-West and 200-East Areas. A groundwater divide trending from southwest to northeast likely exists within the paleochannel in the vicinity of the 200-East Area. Groundwater contamination from the 200-West Area most likely will follow one of two preferential paths along the 
buried paleochannel (Hanford Unit 1), one northwest through Gable Gap and the other southeast toward PUREX and off the plateau southeast of the 200-East Area. Groundwater mounding associated with wastewater discharge in the 200-East Area (primarily B-Pond) has also been dissipating, and will cause the groundwater divide to move to the northwest resulting in possible flow reversals (toward the southeast) for groundwater along most parts of the paleochannel.

Currently, there are only a few wells along the Unit 1 (Hanford formation/PMG [undiff.]) corridor, that portion of the upper unconfined aquifer immediately within the channel northeast and east of the 200-West Area and west of the 200-East Area (Plate 15). Additional characterization and monitoring well control in this region is needed to determine the fate, quantity, and distribution of contamination moving through the area. The interpretation presented in this report suggests that this unmonitored region forms an easterly groundwater preferential flow path that may or may not be merging with contaminant plumes from the 200-East Area. Groundwater preferential flow paths through this area could change as groundwater declines.

\subsubsection{Confined Ringold Aquifer System}

Within the study area, the chemistry of groundwater in the confined Ringold aquifer is not available. The confined Ringold aquifer is not very well characterized in the study area. There is also a lack of groundwater data (i.e., no wells) in the confined Ringold aquifer to the west and southwest of the buried paleochannel unconformity where contamination from the 200-West Area may have entered the aquifer. Carbon tetrachloride as high as $590 \mu \mathrm{g} / \mathrm{L}$ was detected in a 1998 deep borehole drilled below Unit 8 (Hodges and Horton 1999a, 1999b), downgradient from the primary contaminant source. This study suggests that contaminants from the 200 -West Area may be moving through the confined Ringold aquifer (Unit 9), which discharges into Unit 1 (Hanford formation/PMG [undiff.]) within the paleochannel and continues on in the uppermost-unconfined aquifer to the Columbia River.

\subsubsection{Vertical Contaminant Distribution within the Suprabasalt Aquifer System}

Currently, 200-West Area groundwater contaminant plume maps are generated based on data collected from wells screened only within the upper one-fourth of the unconfined aquifer. Confirmation of contaminants located deeper than this shallow monitoring network within the suprabasalt aquifer system have been documented in Williams (1995), Swanson et al. (1999), Barnett (2000), and Johnson et al. (2001). Artificially induced vertical hydraulic heads within the uppermost-unconfined aquifer are implied as the mechanism to explain the presence of contaminants detected deep within the suprabasalt aquifers. Other potential contaminant pathways include old, deep, unsealed boreholes and well casing in/near contaminant source areas.

Groundwater results collected from boreholes sampled deep throughout the suprabasalt aquifer corroborate the deep placement of contaminants. Since 1994, at least four wells around the 200-West Area (Plate 1) have been drilled greater than $50 \mathrm{~m}(164 \mathrm{ft})$ below the water table and depth discrete groundwater samples collected down to and below the Unit 8 (lower mud) confining unit within the suprabasalt aquifer system. While more characterization data are needed to verify the extent and identification of these and other potential deep contaminants, data from these four wells reveal that CCL4, 
nitrate, technetium-99, and tritium exist at higher concentrations deeper in the aquifer than has been previously monitored at the same locations at the water table. Swanson et al. (1999) also documents over 25 wells that are screened and sampled from depths at least $10 \mathrm{~m}(33 \mathrm{ft})$ beneath the water table. Williams (1995) documented vertical borehole sample data (Figure 4.7) that profiles groundwater contaminant distributions to the bottom of the unconfined aquifer at a depth of over $40 \mathrm{~m}(131 \mathrm{ft})$ below the water table. The location of this borehole, well 699-36-70A, at the southeast corner of the 200-West Area (Plate1), indicates that deep-seated groundwater contamination has been transported a considerable distance downgradient from the source areas (see also vertical sample depth profile on Lines 1 and 4 ). Johnson et al. (2001) most recently released a paper documenting similar contaminants detected in three boreholes to the base of the unconfined aquifer and lower within the Ringold confined aquifer (Unit 9) (Figures 4.8-4.10). Profiles of these wells, and the groundwater sample points, are illustrated on Line 2 (Plate 9). The scenario developed to explain/account for the depth distribution of contaminants and to account for groundwater movement and mound development beneath the 200-West Area is presented below.

Since the late 1940s, subsurface liquid waste disposal cribs, ponds and ditches created artificial groundwater mounds and radial driving forces (increased head and vertical downward gradient) in the uppermost-unconfined aquifer (Unit 5), which were transmitted downward toward the confined aquifer, increasing the potentiometric head and driving contaminants deeper into the upper aquifer to the top of the confining Unit 8 (Figure 4.11). These artificial sources have far exceeded any natural recharge into the 200-West Area.

Additional vertical hydraulic forces may have been encountered by contaminants migrating along downgradient flow paths. As contaminants constrained in groundwater moved eastward, other, more recent, disposal episodes created vertically downward driving forces that were subsequently added to the aquifer from above. It is likely that these additional releases displaced the existing shallow contaminants either laterally or vertically deeper into the aquifer (Figure 4.12). The vertical addition of contaminant/ effluent releases from other sources would also tend to chemically alter, i.e., diluting the existing contaminants moving beneath the release site.

Barnett (2000) provides a present-day example of this deep displacement mechanism, which is occurring at the SALDS. The SALDS, an effluent disposal facility, is located at the north end of the 200-West Area (Plate 1) over that portion of the unconfined aquifer where the Ringold Unit 8 confining interval is absent. The unconfined aquifer in this area is approximately $65 \mathrm{~m}(213 \mathrm{ft})$ in thickness with basalt as the lower confining unit; groundwater flows to the north-northeast (Plates 6 and 10). SALDS disposes radioactive tritium-contaminated wastewater. Two shallow groundwater monitoring wells were installed, one up- and one downgradient to monitor effluent releases from the facility. In addition, one deep groundwater-monitoring well was installed downgradient with a sample point approximately $24 \mathrm{~m}$ (79 ft) below the water table. As discussed in Barnett (2000), initially, the liquid effluent disposed to SALDS moved through the vadose zone along south dipping bedding planes (e.g., the Plio-Pleistocene silt and caliche [hydrogeologic Units 2 and 3]) (Figure 4.13). Because of this vadose flow path, the waste stream break through to groundwater (first significant tritium activity increase) was first observed in June 1996 in the upgradient well 699-48-77A located south of the SALDS disposal ponds. Tritium concentrations increased, in the shallow downgradient well (699-48-77D) a little over 12 months after detection in 

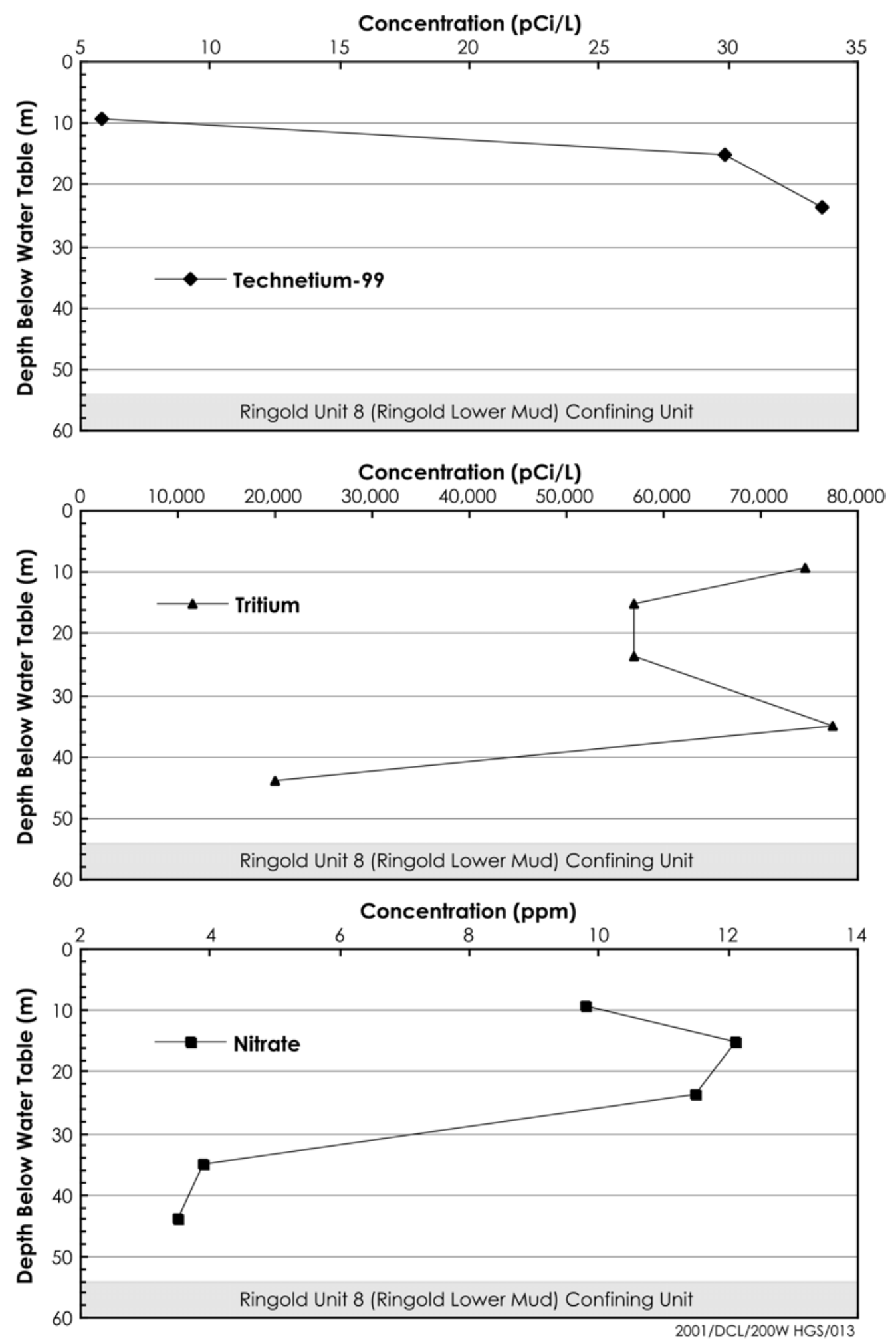

Figure 4.7. Depth Distribution of Key Contaminants, Well 699-36-70A, 200-West Area 


\section{Concentration $(\mathrm{pCi} / \mathrm{L})$}
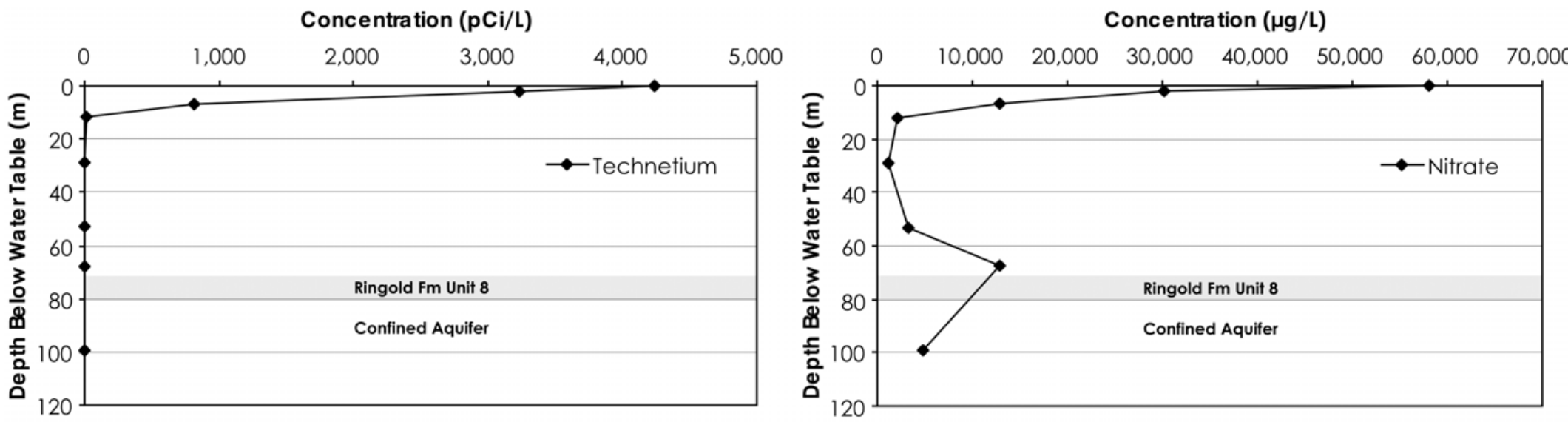

u
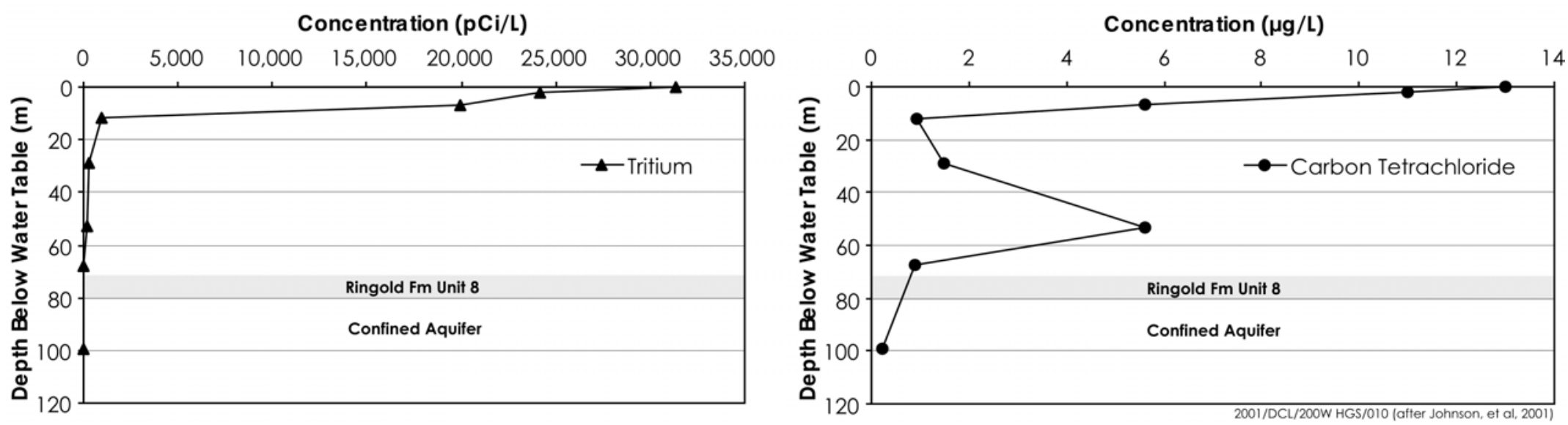

Figure 4.8. Depth Distribution of Key Contaminants, Well 299-W22-50, Waste Management Area S-SX 

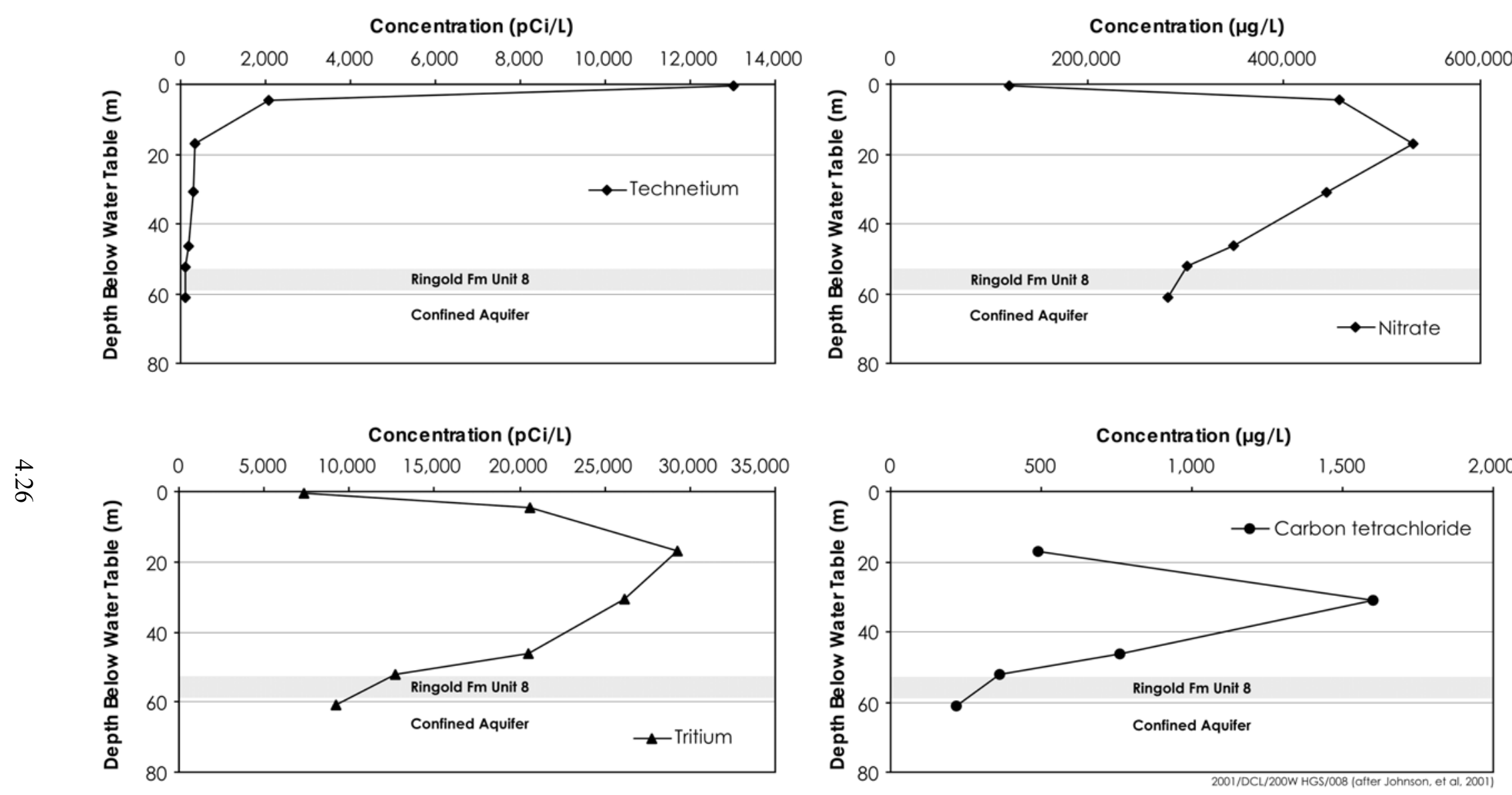

Figure 4.9. Depth Distribution of Key Contaminants, Well 299-W10-24, Waste Management Area T 

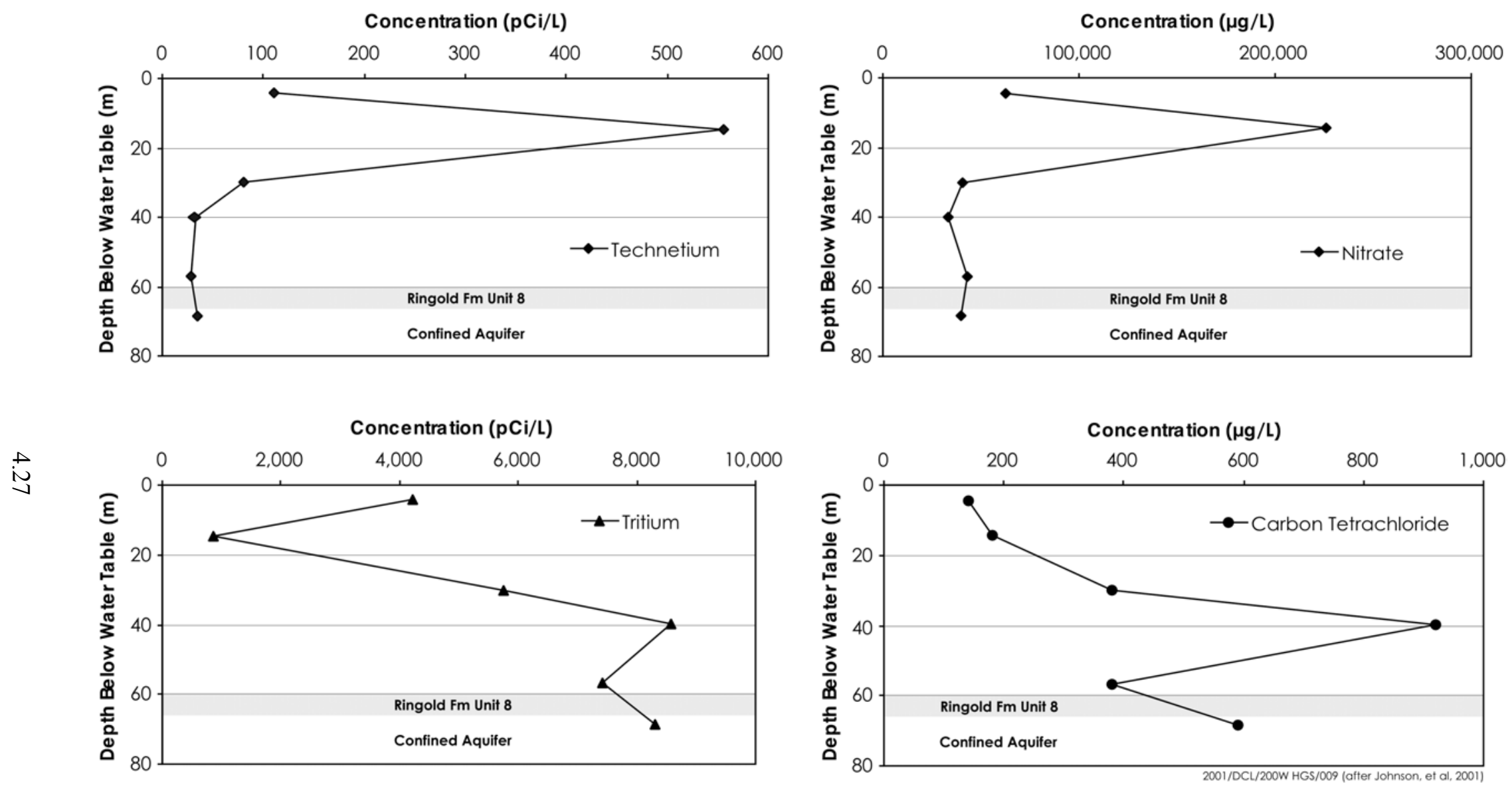

Figure 4.10. Depth Distribution of Key Contaminants, Well 299-W14-14, Waste Management Area TX-TY 


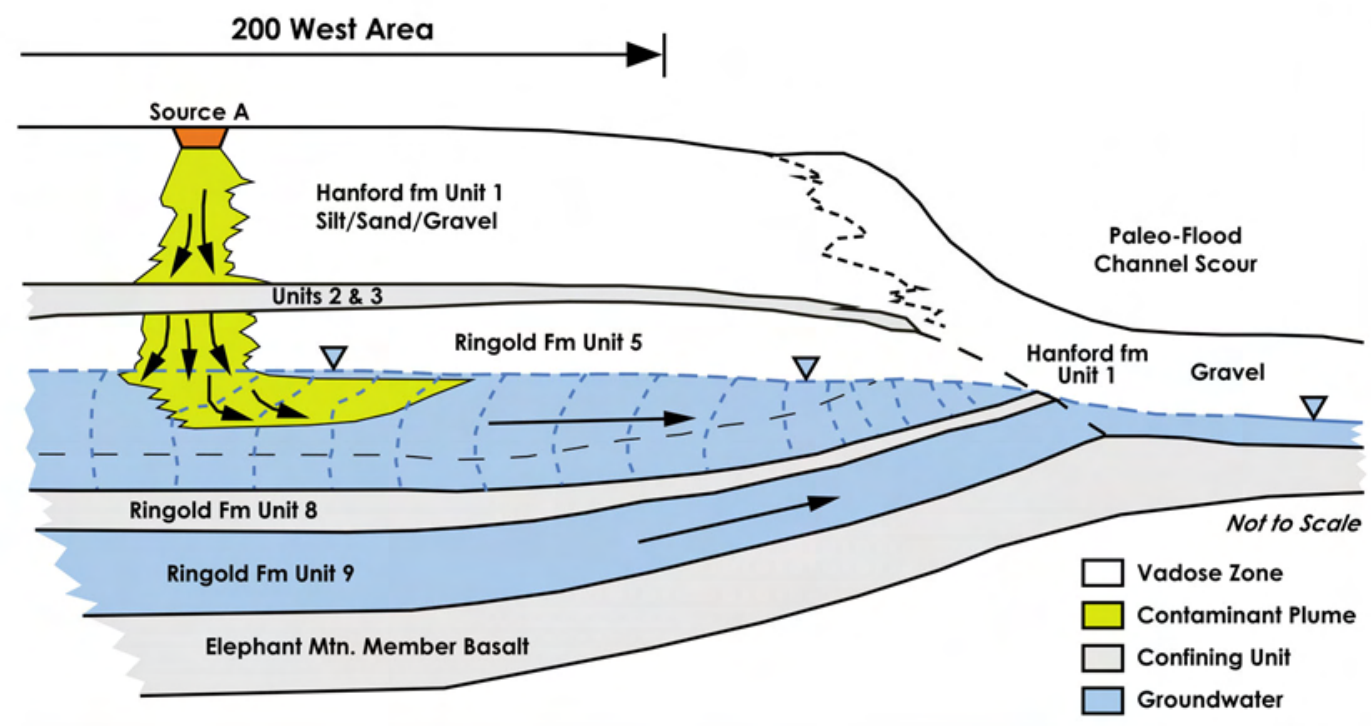

2001/DCL/200W HGS/011

Figure 4.11. Single-Source Groundwater Contaminant Plume Conceptual Model for the 200-West Area Illustrating Hypothetical Plume Migration

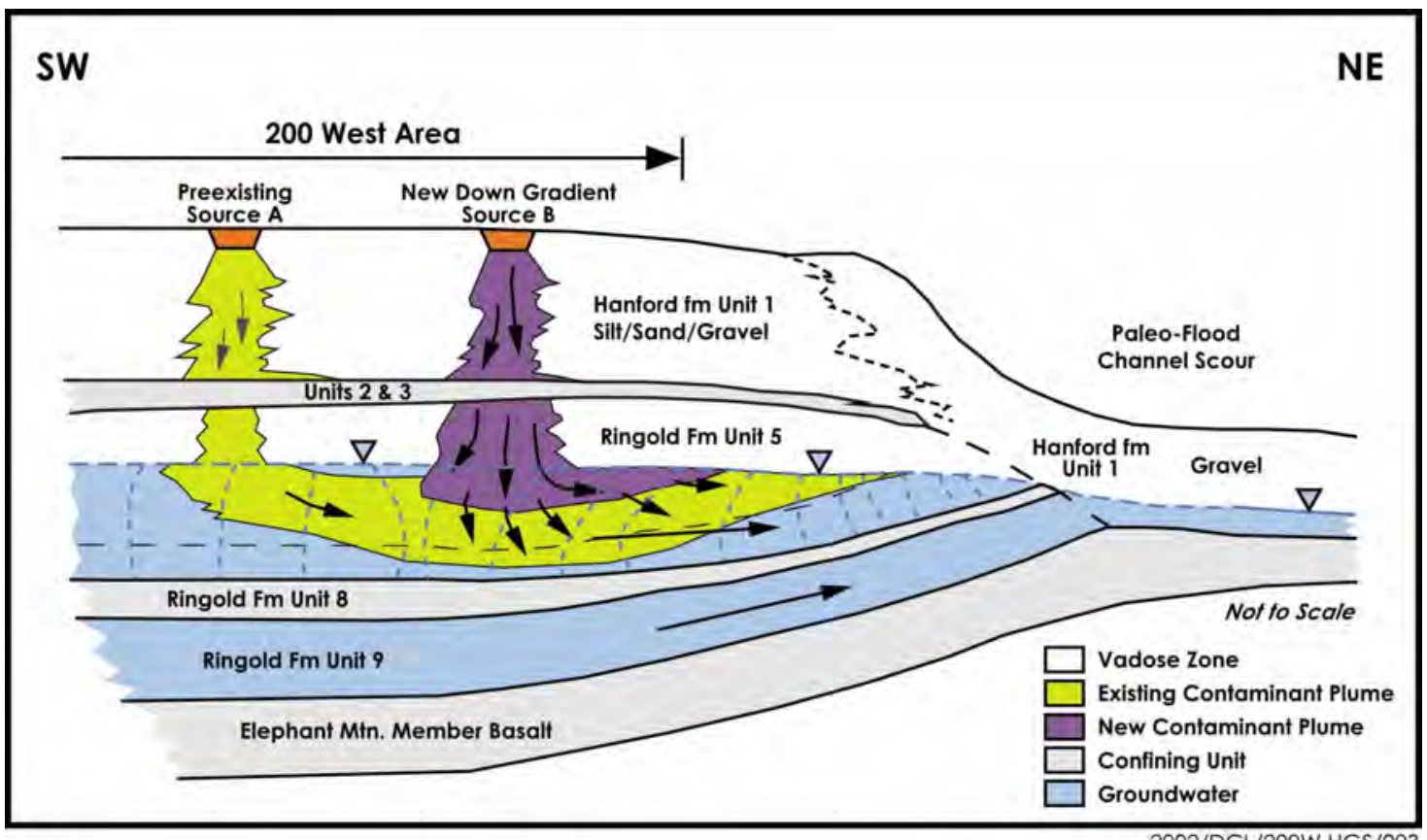

Figure 4.12. Multiple-Source Contaminant Plume Conceptual Model for the 200-West Area Illustrating Vertical Displacement of Pre-Existing Plume by More Recent Contaminant Source 


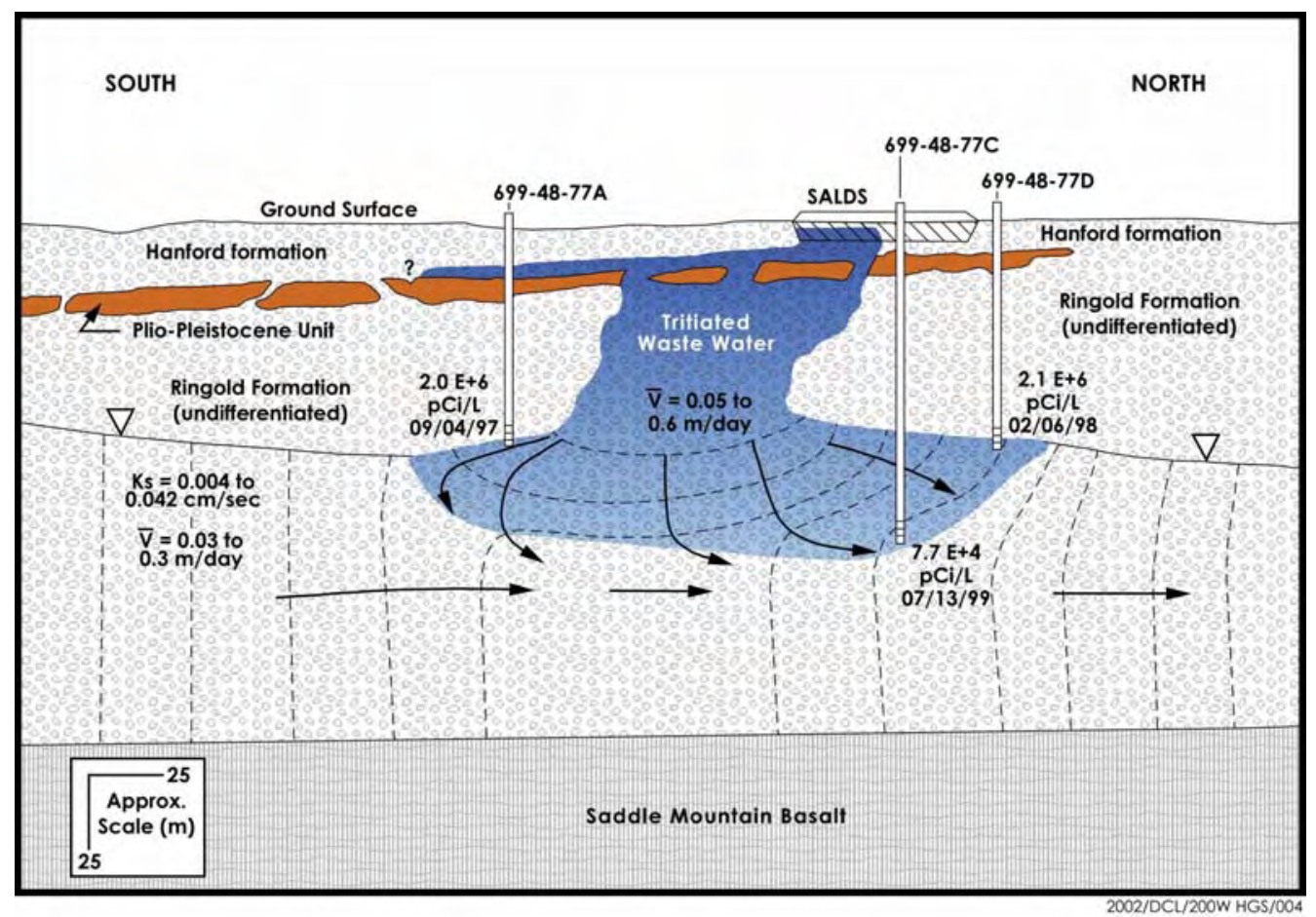

Figure 4.13. Groundwater Contaminant Plume (Tritium) Conceptual Model for State-Approved Land Disposal Site (SALDS) Illustrating Vertical and Horizontal (flow lines) Influence on Upper Unconfined Aquifer (after Barnett 2000)

upgradient well 699-48-77A, indicating plume breakthrough/groundwater migration downgradient (north). Finally, tritium concentrations began to increase in the deep well 699-48-77C in 1999 (over 12 months after detection in downgradient well 699-48-77D), indicating an influx of this new source of tritium (Figure 4.14). Barnett illustrates the vertical gradient created by SALDS in Figure 4.13. Figure 4.15 provides groundwater sample results from well $699-48-77 \mathrm{C}$, which illustrate dramatic decreases in known regional contaminants (nitrate and carbon tetrachloride) detected in the well. These decreases are occurring at the same time as tritium breakthrough occurs as evidenced by the simultaneous increase in tritium concentration on Figure 4.15. These data indicate that regional contaminants (e.g., carbon tetrachloride and nitrate), already detected at depths greater than $24 \mathrm{~m}(79 \mathrm{ft})$ below the water table, are being physically displaced and/or chemically diluted by the addition of this new effluent source. As comparison, effluent disposal volumes at SALDS (through 2000) is approximately 390 million liters whereas effluent disposed at U Pond through 1985 was over 165 billion liters, and effluent volumes disposed to the Z-1 and Z-2 cribs (through 1978) was 33.7 million liters (DOE/RL 1993). The data clearly show that effluent (including contaminants) is forced downward at great depths into the uppermost-unconfined aquifer within Ringold Unit 5 as a result of vertical hydraulic gradients created by artificial recharge sources. The data also suggest that either or both mechanisms, physical displacement (both laterally and vertically) and chemical dilution, could account for the changing concentrations.

To date, drilling and characterization has been focused primarily on identifying vadose and shallow ( $<10$-m-deep [ $<33$-ft-deep]) groundwater plumes; deep characterization data have been collected from only a limited number of wells. 


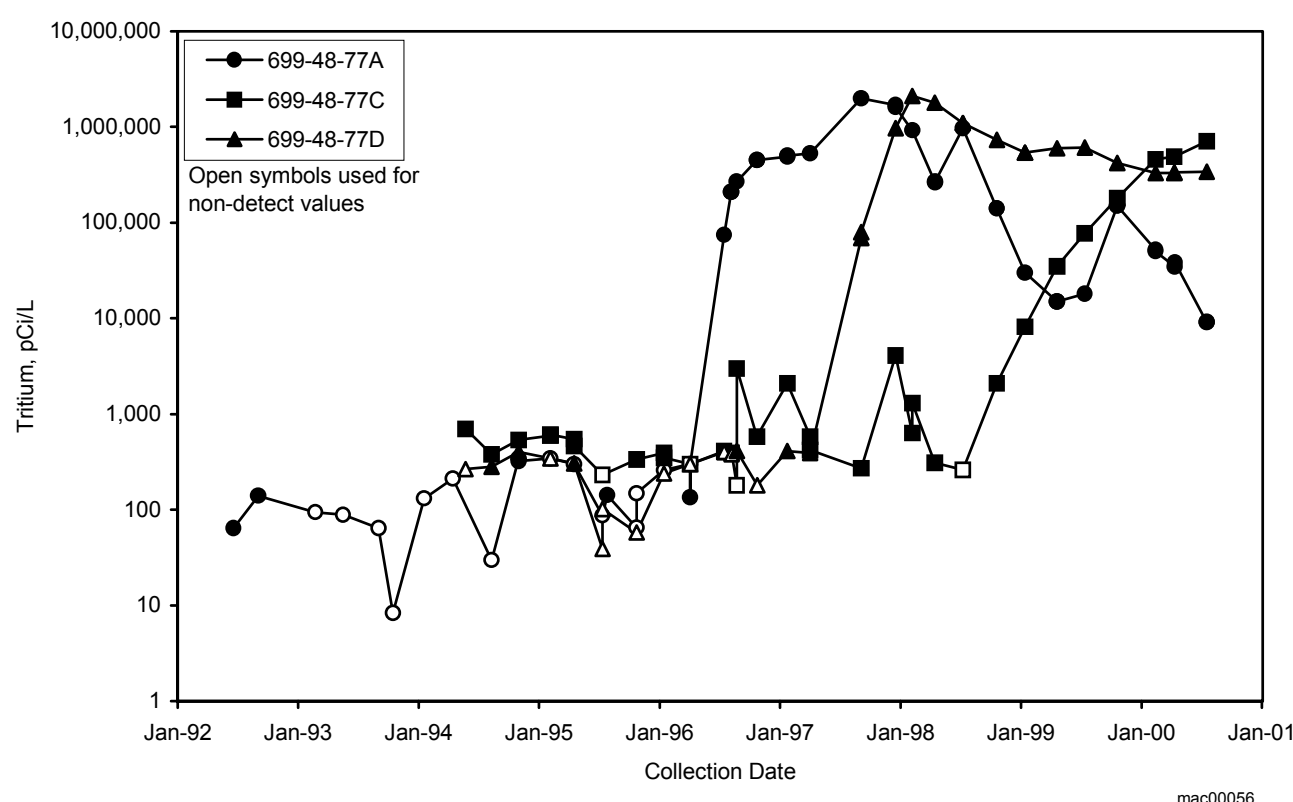

Figure 4.14. Tritium Concentration Trends in Wells Nearest to the State-Approved Land Disposal Site through August 2000. Well 699-48-77C is completed $\sim 24$ meters deeper in the aquifer than wells 699-48-77A and 699-48-77D (after Barnett 2000).

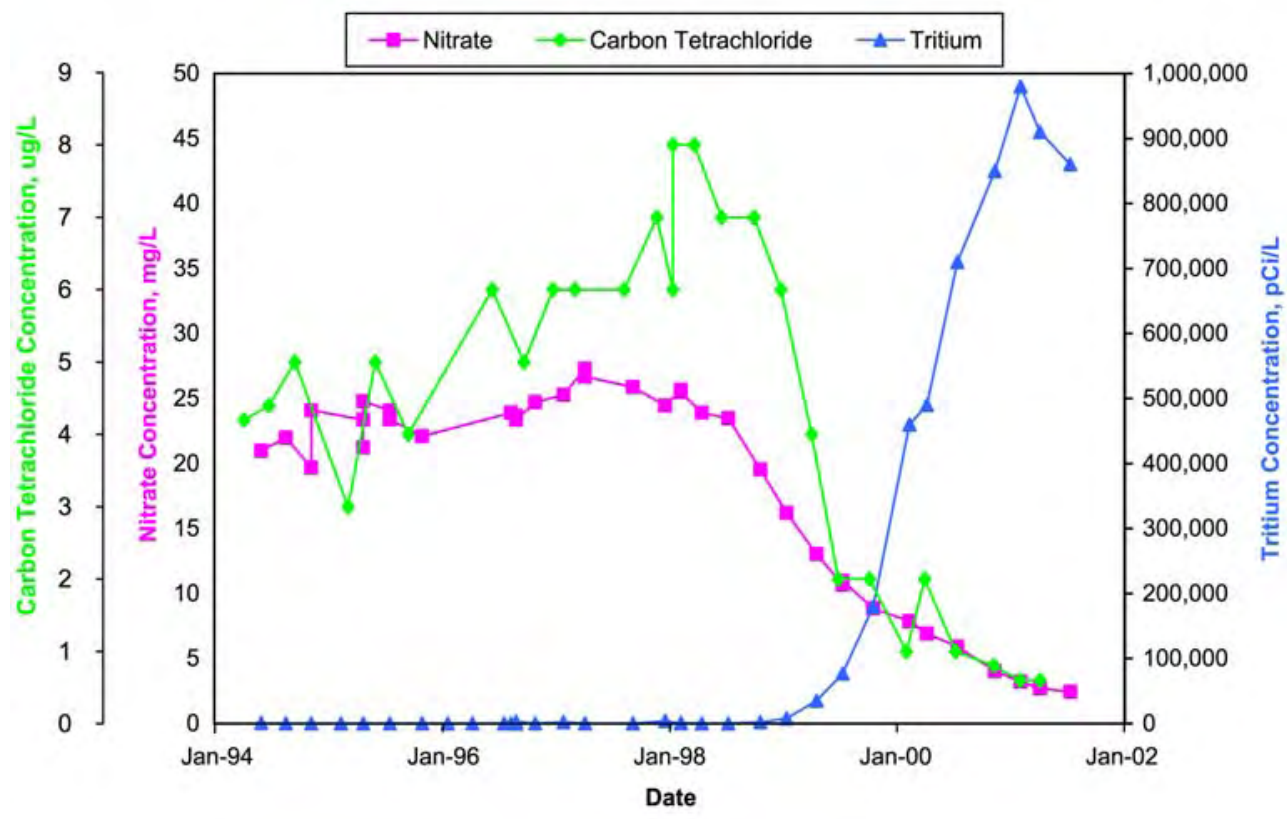

Figure 4.15. Vertical Contaminant Dispersement in Deep Well 699-48-77C 


\subsection{Conclusions}

Conclusions of the 200-East Area revised hydrogeology report (Williams et al. 2000) recommended that more emphasis be placed on separation of the suprabasalt aquifer system into the upper unconfined aquifer and the Ringold confined aquifer. These conclusions also apply to the 200-West Area because data presented in this and previous reports indicate deep contamination exists in both aquifers: 1) the uppermost-unconfined aquifer within the Ringold Formation Unit 5 gravel and adjacent Unit 1 (Hanford formation), and 2) the lower Ringold confined aquifer (where the Unit 9 gravel exists below Unit 8). Most contaminants detected in groundwater are constrained by these two systems. In addition, deep characterization and monitoring well control is important for determining the quantity and distribution of deep-seated past-practice contaminants within the 200-West suprabasalt aquifers and their fate within related groundwater flow paths. New characterization information, when applied to the three-dimensional groundwater numerical flow model and preparation of contaminant and water-table maps, will result in improved determinations of the groundwater flow and contaminant migration patterns and rates.

Conclusions of this report are as follows:

- The two primary contaminant flow paths out of the 200-West Area are well established (Hartman et al. 2001). Hydrogeologic mapping indicates that the confining (aquitard) Ringold Unit 8 (lower mud unit) is located at or near the water table of the upper unconfined aquifer in the northeast portion of the study area, downgradient from 200-West source areas. The position of the Ringold Unit 8 at or near the water table may be splitting or diverting groundwater flow into the two primary flow paths, one northeast and the other southeast of the area, effectively redirecting contaminants either toward the Gable Gap or southeast across the 200-East Area.

- A cataclysmic flood paleochannel(s), eroded into the Ringold Formation north of the 200-West Area, trends northwest to southeast. North and northeast of the 200-West Area within this channel, the aquifer is composed of more permeable Hanford formation sediments, which have a higher hydraulic conductivity compared to the Ringold Units 5 and 9 sediments adjacent to the paleochannel. Groundwater and contaminants from the northern 200-West Area may preferentially flow northeast into this erosional channel. The revised structure maps of the Ringold Units 5 and 8 define the erosional limits of this channel within the Ringold sediments.

- Water level decline in the 200 -West Area is resulting in changes of the contaminant and groundwater preferential flow paths from the 200-West Area toward the river. As declines continue, more of the older Ringold Units 8 and 9 will become exposed above the water table northeast of the 200-West Area near the Gable Gap, restricting groundwater and contaminant flow in that direction and possibly diverting existing contaminant plumes to the southeast.

- Hydrogeologic data for delineating the aquifer boundaries and hydrodynamics are inadequate downgradient of the 200-West Area near Gable Gap and the 200-East Area boundary. The existing groundwater well network is limited and, based on this hydrogeologic conceptual model, provides 
questionable strategic monitoring of the primary or preferential groundwater and plume flow paths within the upper unconfined aquifer and confined Ringold aquifer. The revised hydrogeology presented in this report can aid in the identification of strategic monitoring well locations to improve the tracking and assessment of existing and new regional contaminant plumes leaving the 200 West Area. A few strategically placed monitoring wells also can provide opportunities to gather better characterization data, along with addressing potential data gaps and to test the revised hydrogeologic conceptual model presented in this report.

- Since the 1950s, contaminants have been driven deep into the unconfined aquifer beneath the 200-West Area and vicinity by artificially increased vertical hydraulic heads, a groundwater condition created by large volumes of liquid effluent disposal to cribs, ponds, and ditches. The existing monitoring network consists of wells screened primarily in just the upper one-fourth of the unconfined aquifer and is not adequate to assess or monitor contaminants at depth.

- The uppermost-unconfined aquifer averages about $40 \mathrm{~m}$ (131 ft) thick beneath most of the 200-West Area. Characterization of the lower three-fourths of the unconfined aquifer and the confined Ringold aquifer beneath the 200-West Area and east to the buried paleochannel (near the west side of the 200-East Area) is very limited, and without additional characterization, conceptual models cannot be accurately depicted. The assessment of deep seated contaminants is key to developing successful cleanup options for Hanford's groundwater. 


\subsection{References}

Baker, V. R., B. N. Bjornstad, A. J. Busacca, K. R. Fecht, E. P. Kiver, U. L. Moddy, J. G. Rigby, O. F. Stradling, and A. M. Tallman. 1991. "Quaternary Geology of the Columbia Plateau," In Quaternary Nonglacial Geology; Conterminous United States: The Geology of North America, Vol. K-2, R. B. Morrison (ed.), Geological Society of America, Boulder, Colorado.

Barnett, D. B. 2000. Results of Tritium Tracking and Groundwater Monitoring at the Hanford Site 200 Area State-Approved Land Disposal Site-Fiscal Year 2000. PNNL-13329, Pacific Northwest National Laboratory, Richland, Washington.

Bjornstad, B. N. 1984. Suprabasalt Stratigraphy Within and Adjacent to the Reference Repository Location. SD-BWI-DP-039, Rockwell Hanford Operations, Richland, Washington.

Bjornstad, B. N. 1985. "Late-Cenozoic Stratigraphy and Tectonic Evolution Within a Subsiding Basin, South-Central Washington." Geological Society of America, Abstracts with Programs, v. 17, p. 524.

Bjornstad, B. N. 1990. Geohydrology of the 218-W-5 Burial Ground. PNL-7336, Pacific Northwest Laboratory, Richland, Washington.

Brown, D. J. 1959. Subsurface Geology of the Hanford Separations Areas. HW-61780, Hanford Atomic Products Operation, General Electric Company, Richland, Washington.

Bryce, R. W., G. W. Gee, F. A. Spane, and B. N. Bjornstad. 1991. "Hydrogeology of the Hanford Site: Implications for Contaminant Transport." Geological Society of America Abstracts with Programs, v. 23, no. 5, p. A74.

Busacca, A. J., and E. V. McDonald. 1994. "Regional Sedimentation of Late-Quaternary Loess on the Columbia Plateau: Sediment Source Area and Loess Distribution Patterns." Washington Division of Geology and Earth Resources Bulletin 80, p. 181-190.

Cole, C. R., M. P. Bergeron, S. K. Wurstner, P. D. Thorne, S. Orr, and M. I. McKinley. 2001. Hanford Site-Wide Groundwater Model Calibration Using Inverse Methodology. PNNL-13447, Pacific Northwest National Laboratory, Richland, Washington.

Cole, C. R., S. K. Wurstner, M. P. Bergeron, M. D. Williams, and P. D. Thorne. 1997. ThreeDimensional Analysis of Future Groundwater Flow Conditions and Contaminant Plume Transport in the Hanford Site Unconfined Aquifer System: FY 1996 and 1997 Status Report. PNNL-11801, Pacific Northwest National Laboratory, Richland, Washington.

Connelly, M. P., B. H. Ford, and J. V. Borghese. 1992a. Hydrogeologic Model for the 200-West Groundwater Aggregate Area. WHC-SD-EN-TI-014, Westinghouse Hanford Company, Richland, Washington. 
Connelly, M. P., J. V. Borghese, C. D. Delaney, B. H. Ford, J. W. Lindberg, and S. J. Trent. 1992 b. Hydrogeologic Model for the 200-East Groundwater Aggregate Area. WHC-SD-EN-TI-019, Westinghouse Hanford Company, Richland, Washington.

Delaney, C. D., K. A. Lindsey, and S. P. Reidel. 1991. Geology and Hydrology of the Hanford Site: A Standardized Text for Use in Westinghouse Hanford Company Document and Reports. WHC-SD-ER-TI0003, Rev. 0, Westinghouse Hanford Company, Richland, Washington.

DOE - see U.S. Department of Energy.

Ecology - Washington State Department of Ecology, U.S. Environmental Protection Agency, and U.S. Department of Energy. 1998. Hanford Federal Facility Agreement and Consent Order. Document No. 89-10, Rev. 5 (The Tri-Party Agreement), Olympia, Washington.

Fecht, K. R., S. P. Reidel, and A. M. Tallman. 1987. "Paleodrainage of the Columbia River System on the Columbia Plateau of Washington State-A Summary." In Washington Division of Geology and Earth Resources Bulletin 77. Department of Natural Resources, Olympia, Washington.

Gephart, R. E., F. A. Spane, Jr., L. S. Leonhart, D. A. Palombo, and S. R. Strait. 1979. "Pasco Basin Hydrology." In Hydrologic Studies Within the Columbia Plateau, Washington: An Integration of Current Knowledge, pp. III-1 to III-236. RHO-BWI-ST-5, Rockwell Hanford Operations, Richland, Washington.

Graham, M. J., M. D. Hall, S. R. Strait, and W. R. Brown. 1981. Hydrology of the Separations Area. RHO-ST-42, Rockwell International, Richland, Washington.

Graham, M. J., G. V. Last, and K. R. Fecht. 1984. An Assessment of Aquifer Intercommunication in the B-Pond-Gable Mountain Pond Area of the Hanford Site. RHO-RE-ST-12P, Rockwell Hanford Operations, Richland, Washington.

Hartman, M. J., L. F. Morasch, and W. D. Webber. 2000. Hanford Site Groundwater Monitoring for Fiscal Year 1999. PNNL-13166, Pacific Northwest National Laboratory, Richland, Washington.

Hartman, M. J., L. F. Morasch, and W. D. Webber. 2001. Hanford Site Groundwater Monitoring for Fiscal Year 2000. PNNL-13404, Pacific Northwest National Laboratory, Richland, Washington.

Hodges, F. N., and D. G. Horton. 1999a. Borehole Data Package for 1998 Wells Installed at SingleShell Tank Waste Management Area TX-TY. PNNL-12124, Pacific Northwest National Laboratory, Richland, Washington.

Hodges, F. N., and D. G. Horton. 1999b. Borehole Data Package for 1998 Wells Installed at SingleShell Tank Waste Management Area T. PNNL-12125, Pacific Northwest National Laboratory, Richland, Washington. 
Jensen, E. J. 1987. An Evaluation of Aquifer Intercommunication Between the Unconfined and Rattlesnake Ridge Aquifers on the Hanford Site. PNL-6313, Pacific Northwest Laboratory, Richland, Washington.

Johnson, V. G., T. E. Jones, S. P. Reidel, and M. I. Wood. 1999. Subsurface Physical Conditions Description of the S-SX Waste Management Area. HNF-4936, Lockheed-Martin Hanford Company, Richland, Washington.

Johnson, V. G., and D. G. Horton. 2000. Borehole Data Package for Wells 299-W22-48, 299-W22-49, and 299-W22-50 at Single-Shell Tank Waste Management Area S-SX. PNNL-13200, Pacific Northwest National Laboratory, Richland, Washington.

Johnson, V. G., C. J. Chou, and F. N. Hodges. 2001. Assessing the Vertical Extent of Groundwater Contamination in a Deep Unconfined Aquifer. Submitted to the Journal of Environmental Management, Pacific Northwest National Laboratory, Richland, Washington.

Last, G. V., B. N. Bjornstad, M. P. Bergeron, D. W. Wallace, D. R. Newcomer, J. A. Schramke, M. A. Chamness, C. S. Cline, S. P. Airhart, and J. S. Wilbur. 1989. Hydrogeology of the 200 Areas Low-Level Burial Grounds-An Interim Report, Volume 2: Appendixes. PNL-6820, Vol. 2, Pacific Northwest Laboratory, Richland, Washington.

Last, G. V., D. W. Duncan, M. J. Graham, M. D. Hall, V. W. Hall, D. S. Landeen, J. G. Leitz, and R. M. Mitchell. 1994. 216-U-10 Pond and 216-Z-19 Ditch Characterization Studies. WHC-EP-0707, Westinghouse Hanford Company, Richland, Washington.

Lindsey, K. A. 1995. Miocene- to Pliocene-Aged Suprabasalt Sediments of the Hanford Site, SouthCentral Washington. BHI-00184, Bechtel Hanford Inc., Richland, Washington.

Lindsey, K. S., M. P. Connelly, and B. N. Bjornstad. 1992. Geologic Setting of the 200-West Area: An Update. WHC-SD-EN-TI-08, Westinghouse Hanford Company, Richland, Washington.

Lindsey, K. A., S. P. Reidel, K. R. Fecht, J. L. Slate, A. G. Law, and A. M. Tallman. 1994. "Geohydrologic Setting of the Hanford Site, South-Central Washington." In Geologic Field Trips in the Pacific Northwest, D. A. Swanson and R. A. Haugerud (eds.), 1994 Geological Society of America Annual Meeting, Department of Geologic Sciences, University of Washington, Seattle, Washington. Chapter 1C, pp. $1 \mathrm{C}-1$ to $1 \mathrm{C}-16$.

Myers, C. W., S. M. Price, J. A. Caggiano, M. P. Cochran, W. J. Czimer, N. J. Davidson, R. C. Edwards, K. R. Fecht, G. E. Holmes, M. G. Jones, J. R. Kunk, R. D. Landon, R. K. Ledgerwood, J. T. Lillie, P. E. Long, T. H. Mitchell, E. H. Price, S. P. Reidel, and A. M. Tallman. 1979. Geologic Studies of the Columbia Plateau: A Status Report. RHO-BWI-ST-4, Rev. 0., Rockwell Hanford Operations, Richland, Washington.

NAVD88. 1988. North American Vertical Datum of 1988. 
Reidel, S. P., and K. R. Fecht. 1981. "Wanapum and Saddle Mountains Basalt in the Cold Creek Syncline Area." In Subsurface Geology of the Cold Creek Syncline, RHO-BWI-ST-14, Rockwell Hanford Operations, Richland, Washington.

Slate, J. L. 1996. "Buried Carbonate Paleosols Developed in Pliocene-Pleistocene Deposits of the Pasco Basin, South-Central Washington, U.S.A.” Quaternary International (34-36):191-196.

Spane, F. A., Jr. and W. D. Webber. 1995. Hydrochemistry and Hydrogeologic Conditions Within the Hanford Site Upper Basalt Confined Aquifer System. PNL-10817, Pacific Northwest Laboratory, Richland, Washington.

Stiff, H. A., Jr. 1951. "The Interpretation of Chemical Water Analyses by Means of Patterns.” J. Petrol. Tech. 3:15-17.

Swanson, L. D., V. J. Rohay, and J. M. Faurote. 1999. Hydrogeologic Conceptual Model for the Carbon Tetrachloride and Uranium/Technetium Plumes in the 200 West Area: 1994 through 1999 Update. BHI-01311, Bechtel Hanford Inc, Richland, Washington.

Tallman, A. M., K. R. Fecht, M. C. Marratt, and G. V. Last. 1979. Geology of the Separation Areas, Hanford Site, South-Central Washington. RHO-ST-23, Earth Sciences Group Research Department, Rockwell International, Richland, Washington.

Tallman, A. M., J. T. Lillie, and K. R. Fecht. 1981. "Chapter 2.0, Suprabasalt Sediments of the Cold Creek Syncline Area." In Subsurface Geology of the Cold Creek Syncline, C. W. Meyers and S. M. Price (eds.), RHO-BWI-ST-14, Rockwell Hanford Operations, Richland, Washington.

Thorne, P. D., and D. R. Newcomer. 1992. Summary and Evaluation of Available Hydraulic Property Data for the Hanford Site Unconfined Aquifer System. PNL-8337, Pacific Northwest Laboratory, Richland, Washington.

Thorne, P. D., M. A. Chamness, F. A. Spane, Jr., V. R. Vermeul, and W. D. Webber. 1993. ThreeDimensional Conceptual Model for the Hanford Site Unconfined Aquifer System, FY 93 Status Report. PNL-8971, Pacific Northwest Laboratory, Richland, Washington.

Thorne, P. D., M. A. Chamness, V. R. Vermeul, Q. C. Macdonald, and S. E. Schubert. 1994. ThreeDimensional Conceptual Model for the Hanford Site Unconfined Aquifer System: FY 1994 Status Report. PNL-10195, Pacific Northwest Laboratory, Richland, Washington.

U.S. Department of Energy (DOE). 1988. Consultation Draft, Site Characterization Plan, Reference Repository Location, Hanford Site, Washington. DOE/RW-0164, Vols. 1 and 2, U.S. Department of Energy, Office of Civilian Radioactive Waste Management, Washington, D.C. 
U.S. Department of Energy, Richland Operations Office (DOE/RL). 1987. Plan and Schedule to Discontinue Disposal of Contaminated Liquids into the Soil Column at the Hanford Site. DOE 065, U.S. Department of Energy, Richland, Washington.

U.S. Department of Energy, Richland Operations Office (DOE/RL). 1993. 200 West Groundwater Aggregate Area Management Study Report. DOE/RL-92-16, Rev. 0, U.S. Department of Energy, Richland, Washington.

U.S. Department of Energy, Richland Operations Office (DOE/RL). 1995. Annual Report for RCRA Groundwater Monitoring Projects at Hanford Site Facilities for 1994. DOE/RL-94-136, Rev. 0, U.S. Department of Energy, Richland, Washington.

U.S. Department of Energy, Richland Operations Office (DOE/RL). 1996. Annual Report for RCRA Groundwater Monitoring Projects at Hanford Site Facilities for 1995. DOE/RL-96-1, Rev. 0, U.S. Department of Energy, Richland, Washington.

Vermeul, V. R., C. R. Cole, M. P. Bergeron, P. D. Thorne, and S. K. Wurstner. 2001. Transient Inverse Calibration of Site-Wide Groundwater Model to Hanford Operational Impacts from 1943 to 1996 Alternative Conceptual Model Considering Interaction with Uppermost Basalt Confined Aquifer. PNNL-13623, Pacific Northwest National Laboratory, Richland, Washington.

Wilbur, J. S., M. J. Graham, and A. H. Lu. 1983. Results of the Separations Area Ground-Water Monitoring Network for 1982. RHO-RE-SR-83-24 P, Rockwell International, Richland, Washington.

Williams, B. A. 1995. Borehole Data Packages for the 216-U-12 Crib Well 699-36-70A, Calendar Year 1994. WHC-SD-EN-DP-091, Westinghouse Hanford Company, Richland, Washington.

Williams, B. A., B. N. Bjornstad, R. Schalla, and W. D. Webber. 2000. Revised Hydrogeology for the Suprabasalt Aquifer System, 200-East Area and Vicinity, Hanford Site, Washington. PNNL-12261, Pacific Northwest National Laboratory, Richland, Washington.

Wood, M. I., T. E. Jones, R. Schalla, B. N. Bjornstad, and F. N. Hodges. 2001. Surface Conditions Description of the T-TX-TY Waste Management Area. RPP-7123, CH2M HILL Hanford Group, Inc., Richland, Washington.

Wurstner, S. K., P. D. Thorne, M. A. Chamness, M. D. Freshley, and M. D. Williams. 1995. Development of a Three-Dimensional Ground-Water Model of the Hanford Site Unconfined Aquifer System: FY 1995 Status Report. PNL-10886, Pacific Northwest Laboratory, Richland, Washington. 


\section{Appendix A}

200-West Area Hydro-Stratigraphy Database 


\section{Appendix A}

\section{0-West Area Hydro-Stratigraphy Database}

\section{A.1 200-West Area Hydrogeology Database}

This appendix presents Table A.1 that denotes the subsurface elevations (structural top) and thickness (isopach) for the hydrogeologic units defined in wells and boreholes within the study area (Figure 1.3). The following section defines the column headings in the table and what they represent.

\section{A.2 Contents of Table A.1}

Table A.1 is a listing of the hydrogeologic units identified in selected wells and/or boreholes within the study area. Each well is identification under the Well Number column. The values in this table are denoted in feet and are rounded to the nearest foot. All values, except the Total Depth column are reported in feet above mean sea level. Total Depth is the total depth drilled in the borehole below ground surface. The brass cap elevation for each well is documented as the surface elevation in the Surface Elev. column, for each well and is reported in NAVD88 or a conversion of the older NGVD29 datum using Corpson (U.S. Army Corps of Engineers 1997). Geophysical log evaluations were used extensively in correlating and selecting the hydrogeologic unit boundaries, i.e., unit tops. The Geophysics column defines, by either a "yes," "no," or "Partial," if geophysical logs were available for the correlation. The following columns present either the unit elevation (top) or the units total (gross) thickness (isopach) if the unit could be defined in the borehole (well) hydrogeologic data evaluation. These units correspond to the hydrogeologic units depicted in Figure 3.1 and throughout the study. The Ring Top column represents the top of the Ringold Formation. The E Gravel (5) Top represents the top of the Ringold Formation Unit 5 gravel. The (5) Isopach column represents the thickness of Unit 5. The Rmud (8) Top represents the top of the Ringold Formation Unit 8 (lower mud) unit. (8) Isopach represents the thickness of Unit 8. Ring A (9A) Top represents the top of the Ringold Formation Unit 9A. Rmud (9B) Top represents the top of the Ringold Formation Unit 9B. (9B) Isopach represents the thickness of Unit 9B. (9A) Isopach represents the thickness of Unit 9A. (9)C Top represents the top of the Ringold Unit 9C. (9C) Isopach represents the thickness of Unit 9C. Basalt Top represents the top of the Elephant Mountain Member Basalt. Comments present the authors notes about an individual well.

\section{A.3 References}

NAVD88. 1988. North American Vertical Datum of 1988.

NGVD29. 1929. National Geodetic Vertical Datum of 1929. 
U.S. Army Corps of Engineers. 1997. Corpson, Version 5.x, Technical Documentation and Operating Instructions. Geodetic Applications Division, Topographic Applications Laboratory, U.S. Army Topographic Engineering Center, Alexandria, Virginia. 
Table A.1. 200-East Area Hydrogeology Database

\begin{tabular}{|c|c|c|c|c|c|c|c|c|c|c|c|c|c|c|c|}
\hline Well Number & $\begin{array}{c}\text { Surface } \\
\text { Elev. }\end{array}$ & Geophysics & $\begin{array}{l}\text { Ring. E } \\
\text { (5) Top }\end{array}$ & (5) isopach & \begin{tabular}{|l|} 
Rmud \\
(8) Top \\
\end{tabular} & (8) Isopach & $\begin{array}{l}\text { Ring A } \\
\text { (9A) Top } \\
\end{array}$ & (9A) Isopach & \begin{tabular}{|c|} 
Rmud \\
(9B) Top \\
\end{tabular} & (9B) Isopach & (9C) Top & $\begin{array}{c}9 \mathrm{C}) \\
\text { Isopcah } \\
\end{array}$ & Basalt Top & Total Depth & Comments \\
\hline 699-44-64P & 727 & Yes $\mathrm{g}, \mathrm{n}$ & 455 & 47 & 410 & 18 & 392 & 25 & 367 & 3 & 364 & 79 & 285 & 452 & $\begin{array}{l}\text { Gravel may all be Hanford not } \\
\text { Unit } 5\end{array}$ \\
\hline $699-51-63$ & 574 & Yes & 0 & 0 & 0 & 0 & 396 & 5 & 0 & 0 & 0 & 0 & 391 & 185 & Driller log \\
\hline 699-48-77A/B & 676 & Yes & 589 & 310 & 0 & 0 & 279 & 60 & 0 & 0 & 0 & 0 & 219 & 458 & $\begin{array}{l}\text { Geo log, no lower mud (unit 8), } \\
\text { unit } 5 \text { is very thick }\end{array}$ \\
\hline $699-51-75$ & 643 & Yes & 543 & 165 & 0 & 0 & 378 & 115 & 0 & 0 & 0 & 0 & 263 & 382 & $\begin{array}{l}\text { Bjorn/drillers log, silt break is } \\
\text { possible mud unit, (5) is thick }\end{array}$ \\
\hline $699-55-76$ & 585 & Yes & 0 & 0 & 0 & 0 & 438 & 76 & 0 & 0 & 0 & 0 & 362 & 238 & $\begin{array}{l}\text { Drillers log, gp logs, brown clay } \\
\text { in (9) }\end{array}$ \\
\hline 699-55-70 & 571 & Yes & 0 & 0 & 0 & 0 & 481 & 115 & 0 & 0 & 0 & 0 & 366 & 205 & Drillers log, brown clay/silt in (9) \\
\hline 299-W14-14 & 671 & Yes & 549 & 280 & 269 & 36 & 233 & $>6^{\prime}$ & NDE & NDE & NDE & NDE & NDE & 443 & $\begin{array}{l}\text { Geo log, gp, wtr smples, chem } \\
\text { soil U-Kick, compare GP to } \\
\text { W11-26 }\end{array}$ \\
\hline 299-W10-24 & 686 & Yes & 560 & 277 & 283 & 15 & 268 & $>15$ & NDE & NDE & NDE & $\mathrm{NDE}$ & NDE & 433 & $\begin{array}{l}\text { Geo log, gp, wtr smples, chem } \\
\text { soil U-Kick, compare GP to } \\
\text { W11-26 }\end{array}$ \\
\hline 299-W11-26 & 697 & Yes & 556 & 271 & 285 & 18 & 267 & 74 & 0 & 0 & 0 & 0 & 193 & 515 & $\begin{array}{l}\text { Geo log, GP, cored well, K=.9864 } \\
\mathrm{cm} / \mathrm{d} \text { (unit 8) }\end{array}$ \\
\hline 299-W14-8A & 726 & No & 548 & 237 & 311 & * & * & * & 0 & 0 & 0 & 0 & 190 & 563 & Cored from (5) to basalt \\
\hline 299-W14-9 & 680 & Yes & 546 & 291 & 254 & 44 & 210 & 60 & 0 & 0 & 0 & 0 & 150 & 545 & \begin{tabular}{|l|}
$\begin{array}{l}\text { Good GP logs compare to W14-7, } \\
\text { perched water top of }(5)\left(81^{\prime}\right)\end{array}$ \\
\end{tabular} \\
\hline 299-W19-4 & 717 & No & 455 & 181 & 274 & 22 & 252 & 80 & 0 & 0 & 0 & 0 & 172 & 550 & Drillers log, no GP \\
\hline 299-W19-8 & 703 & Yes & 517 & 247 & 270 & 57 & 213 & 80 & 0 & 0 & 0 & 0 & 133 & 585 & Drillers log \\
\hline 299-W19-10 & 685 & No & 516 & 291 & 225 & 25 & 200 & 84 & 0 & 0 & 0 & 0 & 116 & 573 & Geo log, core \\
\hline 299-W22-24 & 695 & No & 455 & 225 & 230 & 30 & 200 & 72 & 0 & 0 & 0 & 0 & 128 & 575 & Drillers log, samples archived* \\
\hline 299-W22-27 & 681 & $\mathrm{~g}$ & 493 & 260 & 233 & 57 & 176 & 54 & 0 & 0 & 0 & 0 & 122 & 572 & Drillers log, samples archived* \\
\hline 299-W22-50 & 670 & $\mathrm{~g}, \mathrm{n}$ & 496 & 285 & 211 & 36 & * & $53+$ & 0 & 0 & 0 & 0 & $>122$ & 548 & $\begin{array}{l}\text { Geo Log, Vadose Core to } 175.5^{\prime}, \\
\text { GP logs }\end{array}$ \\
\hline 299-W27-2 & 678 & $\mathrm{~g}, \mathrm{n}$ & 458 & 202 & 256 & $>33$ & $\mathrm{NDE}$ & NDE & 0 & 0 & 0 & 0 & $>243$ & 435 & $\begin{array}{l}\text { Geo Log, splitspoon samples of } \\
\text { lower mud, GP }\end{array}$ \\
\hline 299-W15-5 & 672 & $\bar{G}$ & 536 & 291 & 245 & 53 & 192 & 45 & 0 & 0 & 0 & 0 & 147 & 599 & $\begin{array}{l}\text { Drillers Log, after perfing Unit } 5 \\
\text { and } 9 \text { driller reported hearing } \\
\text { water running down the casing }\end{array}$ \\
\hline 299-W6-3 & 700 & G & 603 & 307 & 296 & 6 & 190 & $\mathrm{NDE}$ & 0 & 0 & 0 & 0 & $>262$ & 441 & $\begin{array}{l}\text { Geo Log, CCL4 in vadose @ } \\
240-245^{\prime}\end{array}$ \\
\hline 299-W6-6 & 700 & $\mathrm{G}$ & 594 & 324 & 0 & 0 & * & * & 0 & 0 & 0 & 0 & $>223$ & 472 & Geo Log, GP \\
\hline 299-W6-1 & 704 & G & 606 & $291^{*}$ & 0 & 0 & * & * & 0 & 0 & 0 & 0 & 247 & 476 & Driller log. old GP $\log \sim 320^{\prime}$ \\
\hline $299-W 7-3$ & 677 & G & * & * & 0 & 0 & $273^{*}$ & 69* & 0 & 0 & 0 & 0 & 204 & 477 & Geo Log, old GP $\log$ \\
\hline $699-35-78 \mathrm{~B}$ & 663 & $\mathrm{~g}, \mathrm{n}$ & 503 & 253 & 249 & 76 & 173 & 90 & 0 & 0 & 0 & 0 & 83 & 603 & Bjornstad Geo Log \\
\hline
\end{tabular}


Table A.1. (contd)

\begin{tabular}{|c|c|c|c|c|c|c|c|c|c|c|c|c|c|c|c|}
\hline Well Number & $\begin{array}{l}\text { Surface } \\
\text { Elev. }\end{array}$ & Geophysics & \begin{tabular}{|l|} 
Ring. E \\
(5) Top \\
\end{tabular} & (5) isopach & \begin{tabular}{|l|} 
Rmud \\
(8) Top
\end{tabular} & (8) Isopach & \begin{tabular}{|c|} 
Ring A \\
(9A) Top \\
\end{tabular} & (9A) Isopach & \begin{tabular}{|l|} 
Rmud \\
(9B) Top
\end{tabular} & (9B) Isopach & (9C) Тop & $\begin{array}{c}(9 \mathrm{C}) \\
\text { Isopcah }\end{array}$ & Basalt Top & Total Depth & Comments \\
\hline $699-40-80$ & 659 & $\mathrm{~g}, \mathrm{n}$ & 509 & 288 & 221 & 52 & 169 & 57 & 0 & 0 & 0 & 0 & 112 & 560 & $\begin{array}{l}\text { Bjornstad Geo Log, compare to } \\
\text { W22-50! }\end{array}$ \\
\hline $299-W 18-22$ & 670 & $\mathrm{~g}, \mathrm{n}$ & 520 & 302 & 226 & $>8$ & * & * & 0 & 0 & 0 & 0 & NDE & 455 & Need to find GP logs \\
\hline 299-W10-14 & 701 & $\mathrm{~g}, \mathrm{n}$ & 564 & 309 & 255 & $>16$ & NDE & & & & & & NDE & 462 & Deep monitoring well-top of mud \\
\hline 699-45-78 & 693 & $\mathrm{~g}, \mathrm{n}$ & 518 & 267 & 251 & 40 & 211 & 38 & 0 & 0 & 0 & 0 & 173 & 730 & Bjornstad has Geo Log \\
\hline $699-59-80 \mathrm{~B}$ & 585 & $\mathrm{~g}, \mathrm{n}$ & 0 & 0 & 0 & 0 & 511 & $*$ & 0 & 0 & 0 & 0 & 401 & 198 & Drillers Log, GP logs \\
\hline 699-63-90 & 513 & $\mathrm{~g}, \mathrm{n}$ & 378 & 6 & 372 & 24 & 348 & 75 & 0 & 0 & 0 & 0 & 273 & 253 & Drillers log, GP logs \\
\hline 699-47-60 & 652 & yes & 0 & 0 & 0 & 0 & 0 & 0 & 426 & 22 & 404 & 36 & 368 & 287 & \\
\hline 699-40-62 & 748 & Partial & 436 & 60 & 376 & NDE & NDE & NDE & NDE & NDE & NDE & NDE & NDE & 384 & \\
\hline 699-36-61B & 750 & G & 430 & 78 & 352 & 78 & 274 & 74 & $\mathrm{ND}$ & $\mathrm{ND}$ & $\mathrm{ND}$ & $\mathrm{ND}$ & 200 & 568 & Drillers log \\
\hline 699-36-63A & 745 & G & 480 & $63+$ & NDE & NDE & NDE & NDE & NDE & NDE & NDE & NDE & NDE & 328 & Geo $\log$ \\
\hline 699-36-70A & 706 & $\mathrm{~g}$ & 451 & 177 & 274 & $8+$ & NDE & NDE & NDE & NDE & NDE & NDE & NDE & 440 & $\begin{array}{l}\text { Geo log, K, chem wtr, caco3, unit } \\
8 \text { splitspoons }\end{array}$ \\
\hline 699-38-61 & 745 & $\mathrm{~g}$ & 415 & $28+$ & NDE & NDE & NDE & NDE & NDE & NDE & NDE & NDE & NDE & 358 & Geo $\log$ \\
\hline 699-38-65 & 755 & $\mathrm{~g}$ & 473 & 115 & 358 & 55 & 303 & 74 & ND & ND & ND & ND & 229 & 536 & Drillers log \\
\hline 699-38-70 & 712 & $\mathrm{~g}, \mathrm{n}$ & 462 & $163+$ & NDE & NDE & NDE & NDE & NDE & NDE & NDE & NDE & NDE & 413 & $\begin{array}{l}\text { Drillers log, compare gp logs to } \\
\text { 36-70A }\end{array}$ \\
\hline 699-35-66 & 728 & $\mathrm{~g}, \mathrm{n}$ & 470 & 142 & 328 & $52+$ & NDE & NDE & NDE & $\mathrm{NDE}$ & NDE & NDE & $\mathrm{NDE}$ & 452 & $\begin{array}{l}\text { Drillers log, compare gp logs to } \\
\text { 35-66B (new log) }\end{array}$ \\
\hline $699-32-72 \mathrm{a} / \mathrm{b}$ & 670 & $\mathrm{~g}, \mathrm{n}$ & 430 & 168 & 262 & 47 & 215 & 118 & $\mathrm{ND}$ & ND & ND & ND & 97 & 580 & $\begin{array}{l}\text { Drillers log, compare gp logs to } \\
\text { 32-72B (new w/geo) }\end{array}$ \\
\hline $\mid$\begin{tabular}{||c|}
$699-50-99$ \\
\end{tabular} & 795 & $\mathrm{~g}, \mathrm{n}$ & 557 & 220 & 337 & 4 & 333 & 4 & & & & & 329 & 730 & \\
\hline $699-50-96$ & 802 & G & 556 & 315 & 241 & 69 & 172 & 88 & & & & & 84 & $*$ & \\
\hline 699-47-92 & 811 & $\mathrm{~g}, \mathrm{n}$ & 538 & 279 & 259 & 89 & 170 & 99 & & & & & 71 & 750 & \\
\hline 699-46-85B & 794 & G & 510 & 286 & 224 & 48 & 176 & 89 & & & & & 87 & 723 & \\
\hline 699-55-60B & 576 & $\mathrm{~g}, \mathrm{n}$ & 0 & 0 & np & $\mathrm{np}$ & np & np & np & $\mathrm{np}$ & np & np & NDE & 288 & $\begin{array}{l}\text { Drillers log, aquifer test, } 1,250 \\
\text { gpm, drawdown }=0.87^{\prime}(8 / 44)\end{array}$ \\
\hline 699-55-63 & 575 & no & np & $\mathrm{np}$ & np & $\mathrm{np}$ & $\mathrm{np}$ & np & np & $\mathrm{np}$ & np & np & 396 & 198 & $\begin{array}{l}\text { Drillers log, no wtr found, well } \\
\text { abandoned in } 1944\end{array}$ \\
\hline 699-31-84A & 626 & G & 552 & 311 & 241 & 103 & $138^{*}$ & nd & nd & nd & nd & nd & 20 & 4398 & $\begin{array}{l}\begin{array}{l}\text { Bjornstad geo log, } 1984 \text { BWIP } \\
\text { rpt }\end{array} \\
\end{array}$ \\
\hline $\mid 699-37-92$ & 647 & G & 493 & 272 & 221 & 106 & 115 & 143 & & & & & -28 & 688 & \\
\hline 699-43-91B & 673 & G & 383 & 172 & 210 & 100 & 111 & 96 & & & & & -19 & * & \\
\hline 699-50-85 & 741 & G & 529 & 264 & 265 & 56 & 209 & 63 & & & & & 146 & 600 & \\
\hline 699-57-83A & 580 & G & 377 & 140 & $(5 \& 9)$ & & & & & & & & 237 & 353 & \\
\hline $\mid 699-37-89$ & 637 & No & 488 & 294 & 196 & 82 & 112 & 129 & & & & & -17 & 678 & Bjornstad geo log \\
\hline 699-37-83 & 637 & $\mathrm{~g}, \mathrm{n}$ & 487 & 257 & 230 & 88 & 142 & 122 & & & & & 20 & 626 & Bjornstad geo log \\
\hline 299-W18-1 & 683 & G & 513 & * & NDE & NDE & NDE & NDE & NDE & NDE & NDE & NDE & NDE & 425 & \\
\hline
\end{tabular}


Table A.1. (contd)

\begin{tabular}{|c|c|c|c|c|c|c|c|c|c|c|c|c|c|c|c|}
\hline Well Number & \begin{tabular}{|c} 
Surface \\
Elev.
\end{tabular} & Geophysics & \begin{tabular}{|l} 
Ring. E \\
(5) Top \\
\end{tabular} & (5) isopach & $\begin{array}{c}\text { Rmud } \\
\text { (8) Top } \\
\end{array}$ & (8) Isopach & \begin{tabular}{|c|} 
Ring A \\
(9A) Top \\
\end{tabular} & (9A) Isopach & \begin{tabular}{|c|}
$\begin{array}{c}\text { Rmud } \\
\text { (9B) Top }\end{array}$ \\
\end{tabular} & (9B) Isopach & (9C) Top & $\begin{array}{c}(9 \mathrm{C}) \\
\text { Isopcah } \\
\end{array}$ & Basalt Top & Total Depth & $\begin{array}{c}\text { Comments } \\
\end{array}$ \\
\hline 299-W11-2 & 716 & no & 541 & 263 & 0 & 0 & 278 & 75 & & & & & 203 & 530 & $\begin{array}{l}\text { Drillers Log, Unit } 8 \text { not present, } \\
\text { only silty sand reported }\end{array}$ \\
\hline 699-55-95 & 779 & Yes & 564 & 163 & 401 & 86 & 315 & 48 & & & & & 267 & 530 & \\
\hline 699-55-89 & 607 & Partial & 527 & NDE & NDE & NDE & NDE & NDE & NDE & NDE & NDE & NDE & NDE & 235 & \\
\hline 699-45-69A & 728 & Partial & 568 & 160 & 408 & $48+$ & NDE & NDE & NDE & NDE & NDE & NDE & NDE & 368 & $\begin{array}{l}\text { Drillers log, Unit } 8 \text { appears } \\
\text { present, log not deep enough,1st } \\
\text { wtr @ } 338 \text { (bottom of silt), jumps } \\
\text { up to } 318 \text { (top of silt) }\end{array}$ \\
\hline $699-43-84$ & 652 & $\mathrm{~g}, \mathrm{n}$ & 538 & 322 & 216 & 50 & 166 & 76 & & & & & 90 & 577 & \\
\hline \multicolumn{16}{|c|}{$\begin{array}{l}\text { Geophysics - Where possible geophysical gamma logs were used to delineate the tops and isopach thicknesses of the listed units. } \\
\text { Neutron logs used in the identification of the water table, and vadose moisture zones. } \\
\mathrm{g}=\text { gamma } \log , \mathrm{n}=\text { neutron log, yes }=\operatorname{logs} \text { available, no = no logs available, partial = well is only partially logged. } \\
\text { Elevations are ground surface elevations in NAV88 rounded to the nearest foot. NAV88 =NGVD } 29(\mathrm{ft})+3.444 \mathrm{ft}[1.05 \mathrm{~m}] \text {. } \\
\text { np = Not penetrated. } \\
\mathrm{NDE}=\text { Not deep enough. } \\
\mathrm{ND}=\text { No data available. } \\
\text { *Data is questionable. }\end{array}$} \\
\hline
\end{tabular}




\section{Appendix B}

\section{Units and Open Interval Data Tables for 200-West Area}




\section{Appendix B}

\section{Units and Open Interval Data Tables for 200-West Area}

\section{B.1 Assignment of Units and Update of Data Tables}

This appendix presents Table B.1, which denotes hydrogeologic unit assignments for each well. The assignment of a primary and if applicable secondary unit(s) to each well is based on the open interval and screened interval of the well. The following section addresses the contents and column headings in the table and what they mean. The second section describes how primary and secondary units were assigned to each well.

\section{B.1.1 Contents of Table B.1}

Table B.1 contains specific well construction information and correlates these data with unit designations for hydrogeologic units identified at the Hanford Site. This information is from the PNNL Groundwater Monitoring Project database. Figure 3.1 shows the stratigraphic units underlying the Hanford Site. The hydrogeologic and geologic stratigraphic columns in Figure 3.1 show differences in stratigraphy, primarily within the Hanford and Ringold Formations. Not all these units are present in the 200-West Area. The details of assignment of units is discussed in the main text and summarized in the following section of this appendix.

The headings shown in Table B.1 from left to right are: well name, primary unit, primary unit isolated, all units, unit comments, reference elevation, stickup, OI top bgs (open interval top in feet below ground surface), OI below bgs (open internal bottom in feet below ground surface), screen top bgs (top of the well screen in feet below ground surface), screen bottom bgs (bottom of the well screen in feet below ground surface). Well Name is the Hanford designation number that consists of three parts separated by hyphens. Part one is the area. In this case, all well names are either 200-West Area or 600 Area wells just outside the 200-West Area. Part 2 is a subsection within the area, and part 3 of the name is the well number within that subsection. Part 3 of the well-numbering system refers to chronological sequence with respect to the time the well was completed and entered into the Hanford well system.

Primary Unit refers to the primary unit, which is based on the hydrogeologic interpretations in Wurstner et al. (1995) (Figure 3.1). Units used in this system in descending order are: Unit 1 for the Hanford formation/ pre-Missoula gravel (PMG) (undiff.), Unit 5 for Ringold Formation's uppermost unit E in the Wooded Island member, Unit 8 for Ringold Formation Lower Mud unit, Unit 9, and basalt units of the Columbia River Basalt Group. For decommissioned or abandoned wells the determination of a primary unit cannot be estimated and so a "not applicable (N.A.)" is noted in the column 
Primary Unit Isolated is a question that is answered as Yes or as No with comments. If yes is the answer entered, it means that the well obtains water from just one unit mentioned above. If the answer entered is No, a qualifying notation will follow in the All Units column consisting of the units that are included with the primary water-bearing unit listed first. All Units is a list of the units encountered during well drilling which under certain circumstances may contribute water if the well was not isolated adequately during well construction or completion. Unit Comments are additional comments that may include, but are not limited to, the proximity to the underlying basalt, a unit's depth, well screen placement in relation to confining units, well plugging, or abandonment (i.e., decommissioning in accordance with WAC 173-160).

Reference Elevation is the surveyed ground surface elevation in feet using the North American Vertical Datum of 1988 (NAVD88) or a conversion of the older NGVD29 using Corpson (Version 5.11, U.S. Army Corps of Engineers 1997) if noted to the nearest $10^{\text {th }}$ or $100^{\text {th }}$ of a foot. Where the elevation is only to the nearest foot the elevation is an estimate from the drillers log or an older survey value referenced to the NGVD29.

Stickup refers to the height in feet from the brass marker (Reference Elevation) to the top of the pump support plate that rests generally on the outer well casing or protective outer well housing. In a small percentage of monitoring wells, the pump support plate is inside and below the outer casing. All water-level measurements and pump depths are measured from the pump support plate, whereas all the well construction information is measured from the reference elevation.

The $O I$ includes the vertical extent of the filter pack and, if present, the outer well screen or perforated casing. The well screen interval is always equal to or less than the open interval; that is, the top of the OI is always shallower than the top of the well screen. Likewise, the bottom of the OI is always equal to or deeper than the well screen bottom except if the backfill at the base of the screen overlaps the screen. This is done to alert the user of the data that the permeability characteristics of the backfill are unspecified or unknown. The top and bottom of each well screen is provided in the last two columns. Well screen applies to actual wire wrap well screen or channel pack with dual well screens; it does not include perforated steel casing. That is why some wells in the table do not have a screened interval listed just open interval top and bottom.

\section{B.1.2 Assignment of Unit Designations}

Primarily hydrogeologic units intercepted by the OI guided assignment of unit designations to each well. The designations were part of the new conceptual model described in this report. The conceptual model, including Table B.1, incorporates newly acquired data and updated hydrogeologic interpretations that enables identification of aquifer system boundaries based on hydraulic separation or isolation created by large differences between the hydraulic conductivity of the hydrogeologic units.

Hydrogeologic units in the uppermost unconfined or Ringold confined aquifer systems in stratigraphic descending order are Unit 1 for the Hanford formation/PP(undiff.), Unit 5 for the uppermost Unit $\mathrm{E}$ in the Wooded Island Member, unit 8 (lower mud unit), and Unit 9 for the Ringold Formation. Unit 8 is composed primarily of silt and clay and is the primary isolation layer between Unit 5 and Unit 9. 
Unit 9 may be a single undifferentiated permeable layer in some areas, but frequently can be differentiated into permeable Units $9 \mathrm{a}$ and $\mathrm{c}$ that are separated by a low permeability layer $9 \mathrm{~b}$ (see Williams et al. 2000). Underneath the suprabasalt sedimentary units are the basalt units of the Columbia River Basalt Group. Layers of sedimentary material of varying permeability are sometimes sandwiched in between basalt flows in addition to permeable interflow zones common between some basalt flows. Primary Unit (same as hydrogeologic unit) assignments in Table B.1 are based on the nomenclature developed in Thorne et al. (1993) (see Figure 3.1).

Assignment to specific units was first done using five structural cross-sections used in this report. They are called Lines 1 through 5. Well logs (includes borehole logs) from PNNL's Well Log Library and geophysical logs were used in conjunction with the five cross-section lines of wells to assign unit(s) to each of these 69 wells and a few boreholes. The stratigraphic interpretations and assigned units of the 69 wells were expanded laterally to more than 100 additional wells, and served as the primary basis for assigning the primary and secondary hydrogeologic units shown in Table B.1. Each well log record was reviewed to confirm if the assigned units were reasonable and consistent with the insights provided by the original 60 wells.

\section{B.2 References}

NAVD88. 1988. North American Vertical Datum of 1988.

NGVD29. 1929. National Geodetic Vertical Datum of 1929.

Thorne, P. D., M. A. Chamness, F. A. Spane, Jr., V. R. Vermeul, and W. D. Webber. 1993. ThreeDimensional Conceptual Model for the Hanford Site Unconfined Aquifer System, FY93 Status Report. PNNL-8971, Pacific Northwest National Laboratory, Richland, Washington.

U.S. Army Corps of Engineers. 1997. Corpson, Version 5.x, Technical Documentation and Operating Instructions. Geodetic Applications Division, Topographic Applications Laboratory, U.S. Army Topographic Engineering Center, Alexandria, Virginia.

WAC 173-160. Minimum Standards for Construction and Maintenance of Wells. Washington Administrative Code, Olympia, Washington.

Williams, B. A., B. N. Bjornstad, R. Schalla, and W. D. Webber. 2000. Revised Hydrogeology for the Suprabasalt Aquifer System, 200-East Area and Vicinity, Hanford Site, Washington. PNNL-12261, Pacific Northwest National Laboratory, Richland, Washington.

Wurstner, S. K., P. D. Thorne, M. A. Chamness, M. D. Freshley, and M. D. Williams. 1995. Development of a Three-Dimensional Ground-Water Model of the Hanford Site Unconfined Aquifer System: FY 1995 Status Report. PNL-10886, Pacific Northwest Laboratory, Richland, Washington. 
Table B.1. Hyrdogeologic Unit Assignments

\begin{tabular}{|c|c|c|c|c|c|c|c|c|c|c|}
\hline Well Name & $\begin{array}{c}\text { Primary } \\
\text { Unit }\end{array}$ & $\begin{array}{l}\text { Primary Unit } \\
\text { Isolated }\end{array}$ & All Units & $\begin{array}{c}\text { Unit } \\
\text { Comment }\end{array}$ & $\begin{array}{l}\text { Ref } \\
\text { Elev. }\end{array}$ & Stickup & $\begin{array}{l}\text { OI Top } \\
\text { Bgs }\end{array}$ & $\begin{array}{l}\text { OI Top } \\
\text { Bgs }\end{array}$ & $\begin{array}{l}\text { Screen } \\
\text { Top Bgs }\end{array}$ & \begin{tabular}{|c|} 
Screen \\
Bot Bgs
\end{tabular} \\
\hline 299-W10-14 & 5 & Yes & 5 & & 700.7 & 2.34 & 437 & 447 & 427 & 447 \\
\hline 299-W10-24 & 5 & Yes & 5 & & 685.96 & 2.1 & 221 & 274 & 233 & 268 \\
\hline 299-W11-2 & N.A. & Yes & $5,8,9$, Basalt & $\begin{array}{l}\text { Multiple } \\
\text { piezometers }\end{array}$ & 717.85 & 2 & 250 & 508 & Multiple & Multiple \\
\hline 299-W11-26 & Basalt & Yes & Basalt & & 693.62 & 2.1 & 515 & 515.1 & & \\
\hline 299-W14-14 & 5 & Yes & 5 & & 670.98 & 3 & 204 & 326 & 217 & 252 \\
\hline 299-W14-8A & Basalt & Yes & Basalt & & 724.43 & 2.4 & 563 & 563.1 & & \\
\hline 299-W14-9 & N.A. & No & $5,8,9$, Basalt & $\begin{array}{l}\text { All units } \\
\text { connected }\end{array}$ & 680.05 & 2.2 & 416 & 535 & & \\
\hline 299-W15-14 & Basalt & Yes & Basalt & & 695 & 0.89 & 581 & 581.1 & & \\
\hline 299-W15-5 & Basalt & Yes & $5,8,9$, Basalt & & 672.34 & 1.7 & 565 & 599 & 569 & 599 \\
\hline 299-W18-1 & 5 & Yes & 5 & & 683.29 & 2.6 & 195 & 425 & & \\
\hline 299-W18-22 & 5 & Yes & 5,8 & \begin{tabular}{|l}
$\begin{array}{l}\text { Screen is just } \\
\text { above } 8\end{array}$ \\
\end{tabular} & 670.08 & 2 & 410 & 455 & 416.5 & 447.5 \\
\hline 299-W19-10 & N.A. & No & 5,8,9,Basalt & $\begin{array}{l}\text { All units } \\
\text { connected }\end{array}$ & 681.67 & 2 & 406 & 564 & & \\
\hline 299-W19-4 & 5 & Yes & 5 & & 717.28 & 1.3 & 255 & 421 & & \\
\hline 299-W19-8 & 5 & Yes & $5,8,9$, Basalt & $\begin{array}{l}\text { Backfilled to } \\
245 \mathrm{ft}\end{array}$ & 702.5 & 1 & $244.1 *$ & 244.2 & & \\
\hline $299-W 22-24$ & N.A. & Yes & $5,8,9$, Basalt & \begin{tabular}{|l} 
Multiple \\
piezometers
\end{tabular} & $\begin{array}{c}696.07 \\
*\end{array}$ & * & 220 & 560 & Multiple & Multiple \\
\hline 299-W22-27 & N.A. & Yes & $5,8,9$, Basalt & $\begin{array}{l}\text { Multiple } \\
\text { piezometers }\end{array}$ & 681.41 & 2.75 & 190 & 572 & Multiple & Multiple \\
\hline 299-W22-50 & 5 & Yes & 5 & & 670.49 & 2.1 & 208 & 245 & 218 & 233 \\
\hline 299-W27-2 & 5 & Yes & 5 & & 677.45 & 3.01 & 399.4 & 420 & 406.1 & 416.6 \\
\hline 299-W6-1 & 5 & Yes & 5 & & 704.4 & 1.5 & 230 & 380 & & \\
\hline 299-W6-3 & 5 & Yes & 5 & $\begin{array}{l}\text { Screen is just } \\
\text { above } 8\end{array}$ & 699.98 & 3.34 & 402 & 425 & 409.6 & 419.9 \\
\hline 299-W6-6 & 5 & Yes & 5 & & 710.31 & 3.17 & 406.7 & 435.9 & 418.59 & 429.3 \\
\hline 299-W7-3 & 9 & Yes & 9,5 , Basalt & $\begin{array}{l}\text { No water } \\
\text { from basalt }\end{array}$ & 677.31 & 2.43 & 427 & 476.7 & 449 & 470 \\
\hline $699-31-84 \mathrm{~A}$ & N.A. & & & $\begin{array}{l}\text { Decommis- } \\
\text { sioned } 1989\end{array}$ & 625 & & & & & \\
\hline $699-32-72 \mathrm{~A}$ & 5 & Yes & 5 & & 669.84 & 1.9 & 210 & 270 & & \\
\hline 699-32-72B & 5 & Yes & 5 & & 670.96 & 2 & 211.5 & 253 & 214.6 & 244.9 \\
\hline 699-35-66A & 5 & Yes & $5,8,9$ & \begin{tabular}{|l|} 
Backfilled to \\
$322 \mathrm{ft}$ \\
\end{tabular} & 727.63 & 2.2 & 260 & 322 & & \\
\hline 699-35-66B & N.A. & & & \begin{tabular}{|l} 
Abandoned \\
1994 \\
\end{tabular} & 727 & & & & & \\
\hline 699-35-78B & N.A. & & & $\begin{array}{l}\text { Abandoned } \\
1981\end{array}$ & 660 & & & & & \\
\hline 699-36-61B & 5 & Yes & $5,8,9$, Basalt & $\begin{array}{l}\text { Backfilled to } \\
380 \mathrm{ft}\end{array}$ & 749.77 & 2.8 & 330 & 378.5 & & \\
\hline 699-36-63A & N.A. & & & $\begin{array}{l}\text { Abandoned } \\
1993\end{array}$ & None & & & & & \\
\hline
\end{tabular}


Table B.1. (contd)

\begin{tabular}{|c|c|c|c|c|c|c|c|c|c|c|}
\hline Well Name & $\begin{array}{c}\text { Primary } \\
\text { Unit }\end{array}$ & $\begin{array}{l}\text { Primary Unit } \\
\text { Isolated }\end{array}$ & All Units & $\begin{array}{c}\text { Unit } \\
\text { Comment }\end{array}$ & $\begin{array}{l}\text { Ref } \\
\text { Elev. }\end{array}$ & Stickup & $\begin{array}{l}\text { OI Top } \\
\text { Bgs }\end{array}$ & $\begin{array}{l}\text { OI Top } \\
\text { Bgs }\end{array}$ & $\begin{array}{l}\text { Screen } \\
\text { Top Bgs }\end{array}$ & $\begin{array}{c}\text { Screen } \\
\text { Bot Bgs }\end{array}$ \\
\hline 699-36-70A & 5 & Yes & 5,8 & & 706.12 & 2.7 & 250 & 288 & 258 & 288 \\
\hline $699-37-83$ & N.A. & & & $\begin{array}{l}\text { Decommis- } \\
\text { sioned } 1983\end{array}$ & 636 & & & & & \\
\hline $699-37-89$ & N.A. & & & $\begin{array}{l}\text { Decommis- } \\
\text { sioned } 1983\end{array}$ & 637 & & & & & \\
\hline 699-37-92 & N.A. & & & $\begin{array}{l}\text { Decommis- } \\
\text { sioned } 1994\end{array}$ & 648.76 & 1.9 & & & & \\
\hline 699-38-61 & 5 & Yes & 5 & & 744.52 & 4.06 & 328.8 & 356.5 & 334.1 & 354.4 \\
\hline $699-38-65$ & 9 & Yes & $9,5,8$, Basalt & $\begin{array}{l}\text { No water } \\
\text { from basalt }\end{array}$ & 754.62 & 2.3 & 440 & 536 & 500 & 510 \\
\hline 699-38-70 & 5 & Yes & 5 & & 712.45 & 1.8 & 255 & 290 & & \\
\hline $699-40-62$ & 5 & Yes & 5 & & 750.95 & 0.13 & 335 & 369 & & \\
\hline $699-40-80$ & N.A. & & & $\begin{array}{l}\text { Decommis- } \\
\text { sioned } 1989\end{array}$ & 657 & & & & & \\
\hline 699-43-84 & Basalt & Yes & & & 653.76 & 2 & 577 & 577.1 & & \\
\hline 699-43-91B & N.A. & & & $\begin{array}{l}\text { Decommis- } \\
\text { sioned } 1989\end{array}$ & 671 & 1.06 & & & & \\
\hline 699-44-64P & 9 & Yes & 9,5 , Basalt & $\begin{array}{l}\text { No water } \\
\text { from basalt }\end{array}$ & 723.35 & 2.25 & 316 & 434.9 & & \\
\hline 699-45-69A & 5 & Yes & 5 & $\begin{array}{l}9 \mathrm{ft} \text { below } \\
\text { screen }\end{array}$ & 727.6 & 1.2 & 274 & 316 & 274 & 366 \\
\hline 699-45-78 & N.A. & & & $\begin{array}{l}\text { Decommis- } \\
\text { sioned } 1989\end{array}$ & 689 & & & & & \\
\hline 699-46-85B & N.A. & & & $\begin{array}{l}\text { Decommis- } \\
\text { sioned } 1989\end{array}$ & 794 & & & & & \\
\hline $699-47-60$ & 9 & Yes & $9, \mathrm{H} 1$ & H1 now dry & 652.28 & 2.5 & 250 & 277 & & \\
\hline 699-47-80A, Q & 9 & Yes & $9,5,8$, Basalt & $\begin{array}{l}\text { Plugged } 545 \\
\text { to } 613\end{array}$ & 713.28 & 2.8 & 482 & 545 & 503.1 & 513.1 \\
\hline 699-47-80B & N.A. & & & $\begin{array}{l}\text { Decommis- } \\
\text { sioned } 1989\end{array}$ & 710.16 & & & & & \\
\hline $699-47-80 \mathrm{C}$ & N.A. & & & $\begin{array}{l}\text { Multi-basalt } \\
\text { piezometers }\end{array}$ & 713.97 & & & & & \\
\hline 699-47-80D & N.A. & & & $\begin{array}{l}\text { Decommis- } \\
\text { sioned } 1989\end{array}$ & 713.8 & & & & & \\
\hline 699-47-92A & N.A. & & & $\begin{array}{l}\text { Decommis- } \\
\text { sioned } 1989\end{array}$ & 806.51 & & & & & \\
\hline $699-48-71$ & 5 & Yes & 5 & & 690.16 & 1.65 & 239 & 283.6 & & \\
\hline 699-48-77A & 5 & Yes & 5 & & 675.59 & 2.47 & 206.7 & 237.1 & 212.4 & 232.7 \\
\hline 699-48-77B & N.A. & & & $\begin{array}{l}\text { Abandoned } \\
1992\end{array}$ & 676 & & & & & \\
\hline 699-50-85 & 9 & Yes & $9,5,8$, Basalt & 9 sealed off & 741.14 & 1.56 & 520 & 600 & 520 & 530 \\
\hline $699-50-96$ & N.A. & & & $\begin{array}{l}\text { Decommis- } \\
\text { sioned } 1989\end{array}$ & 798 & 2.1 & & & & \\
\hline 699-50-99 & N.A. & & & $\begin{array}{l}\text { Decommis- } \\
\text { sioned } 1989\end{array}$ & 792 & 2 & & & & \\
\hline
\end{tabular}


Table B.1. (contd)

\begin{tabular}{|c|c|c|c|c|c|c|c|c|c|c|}
\hline Well Name & $\begin{array}{c}\text { Primary } \\
\text { Unit }\end{array}$ & $\begin{array}{l}\text { Primary Unit } \\
\text { Isolated }\end{array}$ & All Units & $\begin{array}{c}\text { Unit } \\
\text { Comment }\end{array}$ & $\begin{array}{c}\text { Ref } \\
\text { Elev. }\end{array}$ & Stickup & $\begin{array}{l}\text { OI Top } \\
\text { Bgs }\end{array}$ & $\begin{array}{l}\text { OI Top } \\
\text { Bgs }\end{array}$ & $\begin{array}{l}\text { Screen } \\
\text { Top Bgs }\end{array}$ & $\begin{array}{l}\text { Screen } \\
\text { Bot Bgs }\end{array}$ \\
\hline $699-51-63$ & H1 & Yes & H1 & & 573.54 & 1.6 & 157 & 182.3 & & \\
\hline $699-51-75$ & 9 & No & 9,5 , Basalt & $\begin{array}{l}5 \mathrm{ft} \text { below } \\
\text { screen }\end{array}$ & 642.63 & 2.25 & 365 & 382 & 370 & 375 \\
\hline 699-55-60B & H1 & Yes & H1 & & 576.32 & 0.84 & 230 & 285 & & \\
\hline $699-55-63$ & N.A. & & & $\begin{array}{l}\text { Abandoned } \\
1944 \text {, dry }\end{array}$ & 575 & & & 178 & & \\
\hline $699-55-70$ & 9 & Yes & $9,5,8$, Basalt & $\begin{array}{l}\text { Basalt just } \\
\text { below }\end{array}$ & 570.96 & 1.33 & 190 & 195 & 189 & 197 \\
\hline $699-55-76$ & 5 & No & $5, \mathrm{H} 1,8$ & $\begin{array}{l}\text { Screen } \\
\text { bottom in } 8\end{array}$ & 585.27 & 1.1 & 141 & 192 & & \\
\hline $699-55-89$ & 5 & Yes & 5 & & 606.7 & 1.2 & 160 & 214 & & \\
\hline 699-55-95, Q & 5 & No & $5,8,9$, Basalt & $\begin{array}{l}\text { Backfilled to } \\
516 \mathrm{ft}\end{array}$ & 779.14 & 2 & 325 & 515 & 450 & 460 \\
\hline 699-57-83A & H1 & Yes & H1,5,9,Basalt & $\begin{array}{l}\text { Backfilled to } \\
195 \mathrm{ft}\end{array}$ & 579.81 & 1.47 & 150 & 194.3 & & \\
\hline 699-59-80B & H1 & Yes & H1 & $\begin{array}{l}\text { Backfilled to } \\
183 \mathrm{ft}\end{array}$ & 584.61 & 2 & 152 & 183 & & \\
\hline $699-63-90$ & 5 & No & $5,8,9$, Basalt & $\begin{array}{l}\text { Pipe plugged } \\
\text { at } 160 \mathrm{ft}\end{array}$ & 512.73 & 1.9 & 115 & 163 & & \\
\hline
\end{tabular}




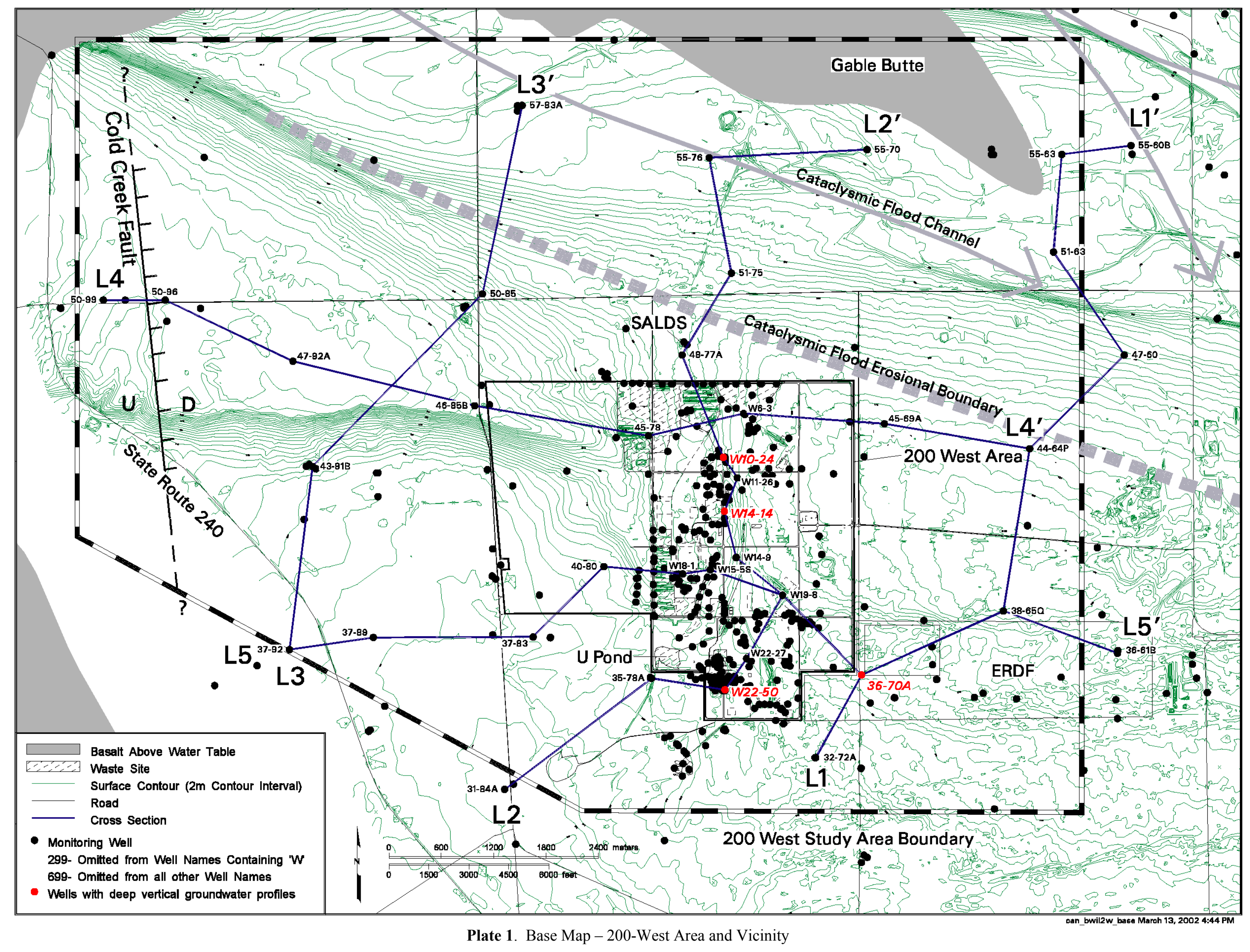




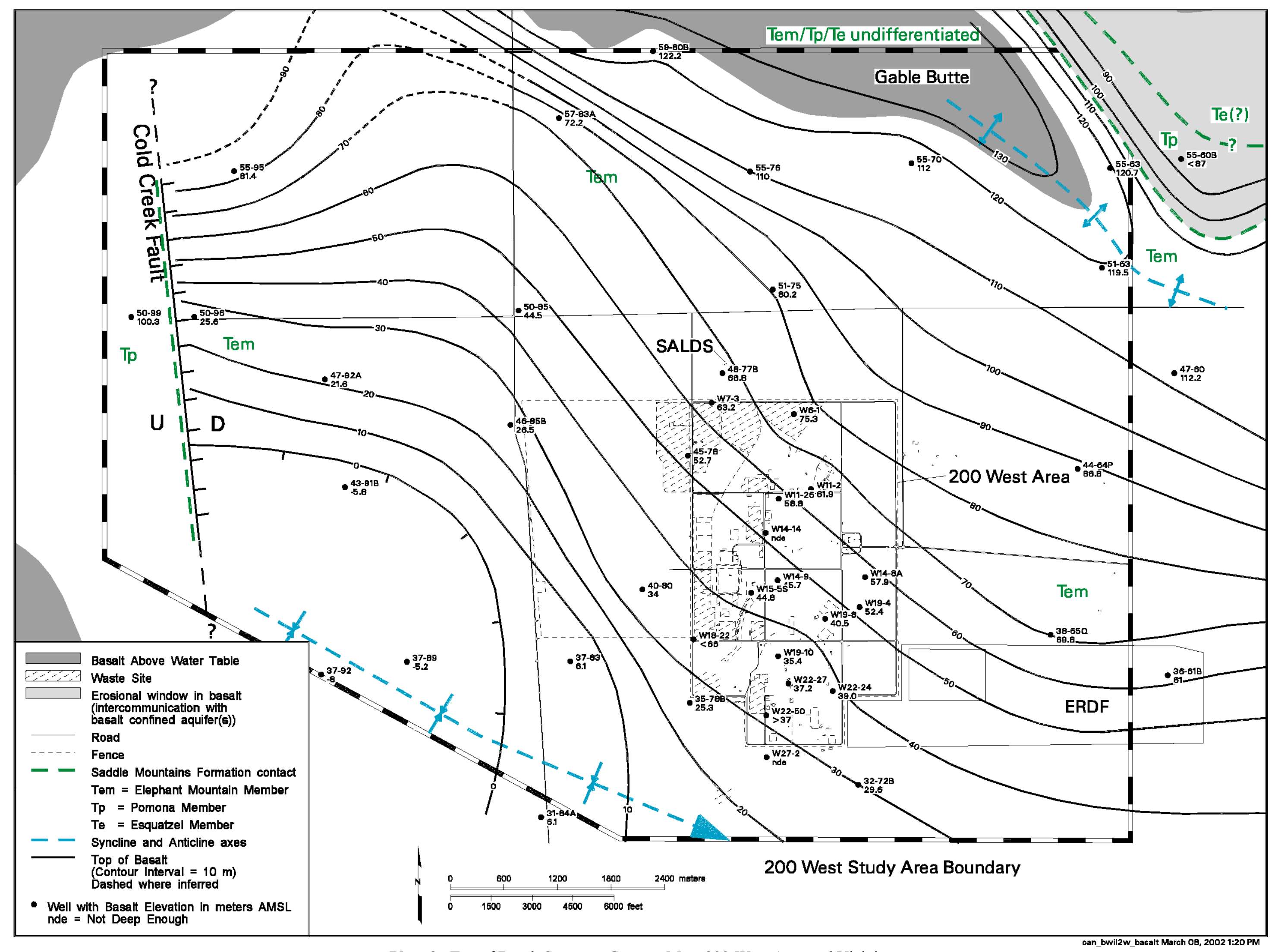

Plate 2. Top of Basalt Structure Contour Map, 200-West Area and Vicinity 


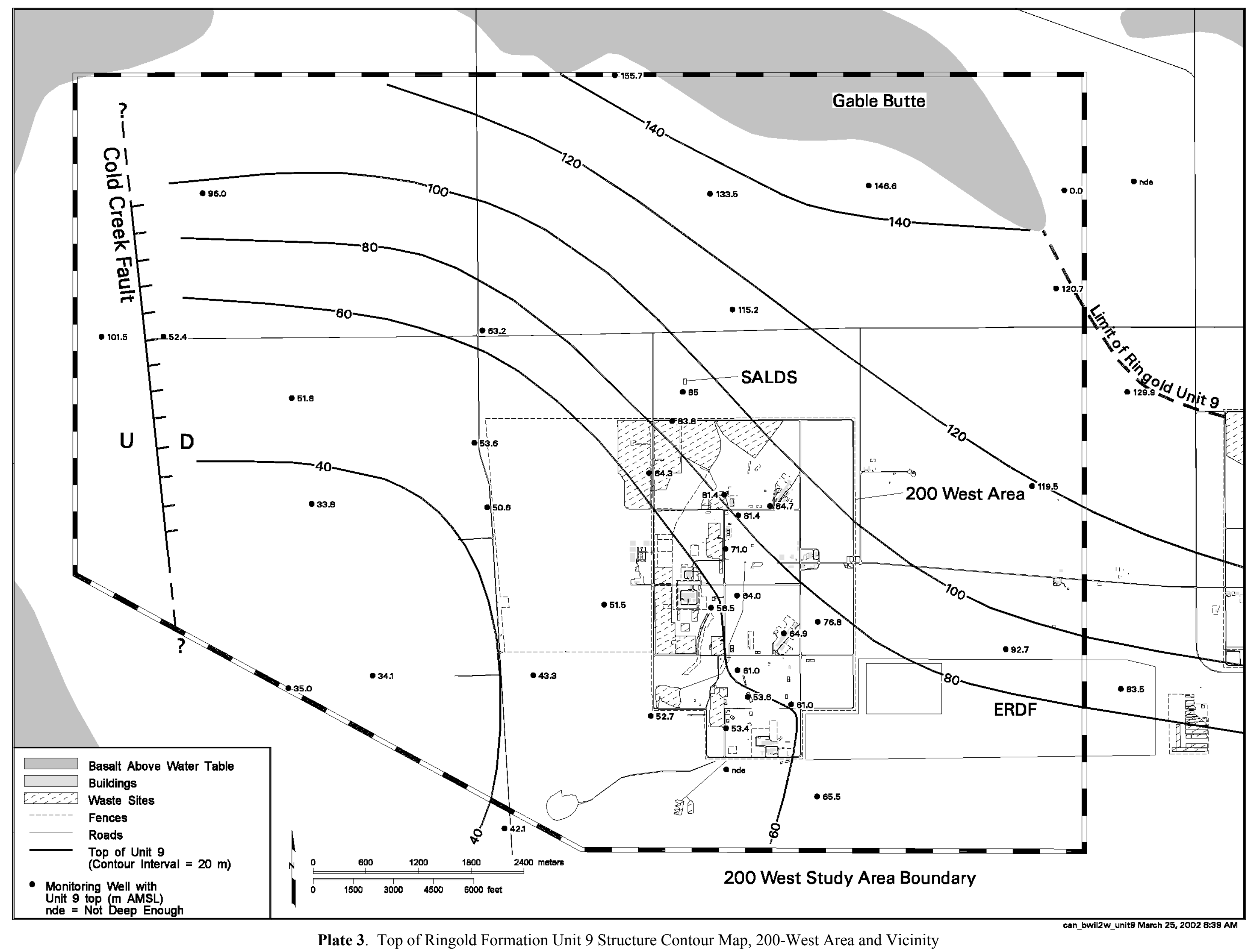




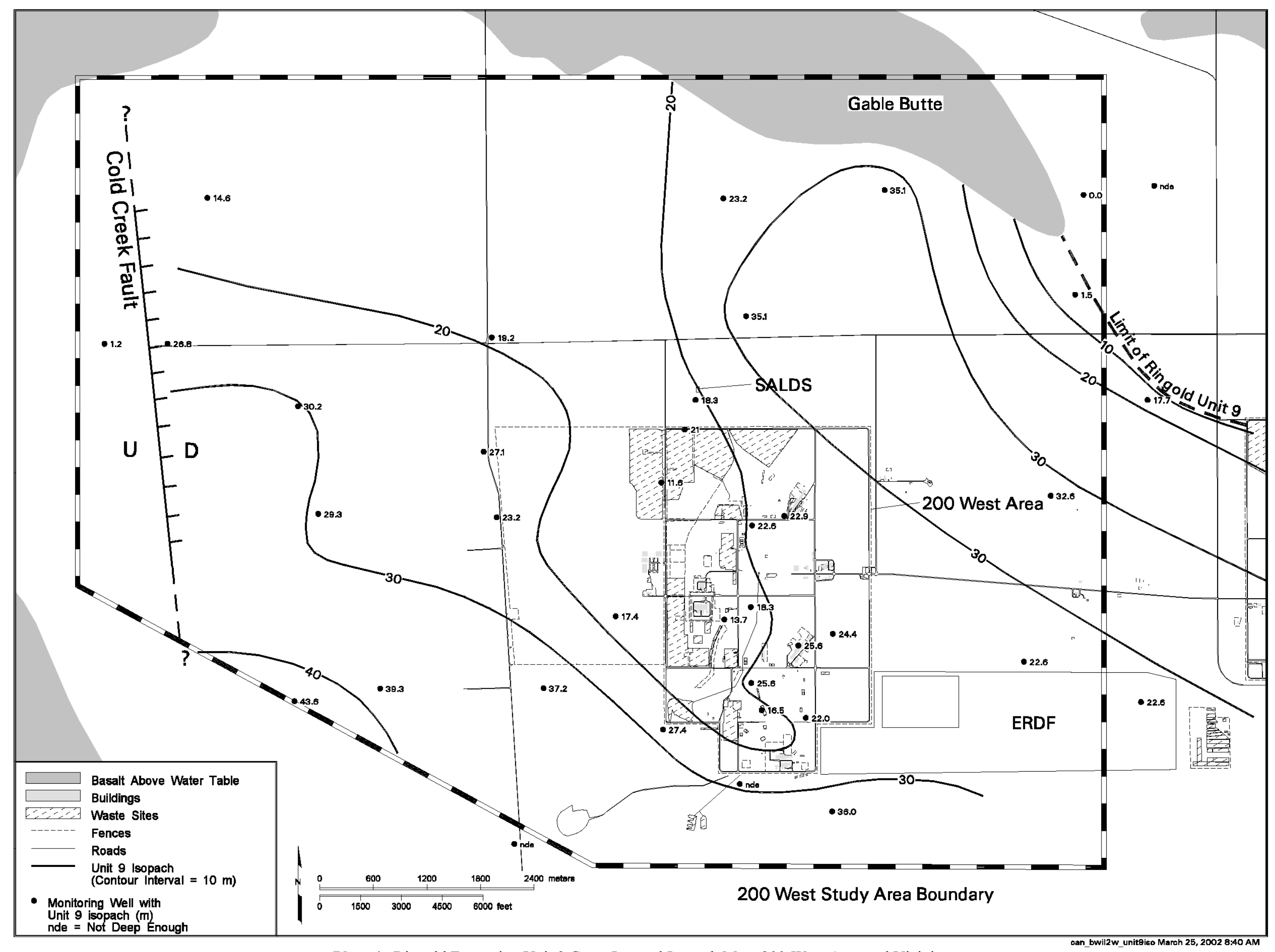

Plate 4. Ringold Formation Unit 9 Gross Interval Isopach Map, 200-West Area and Vicinity 


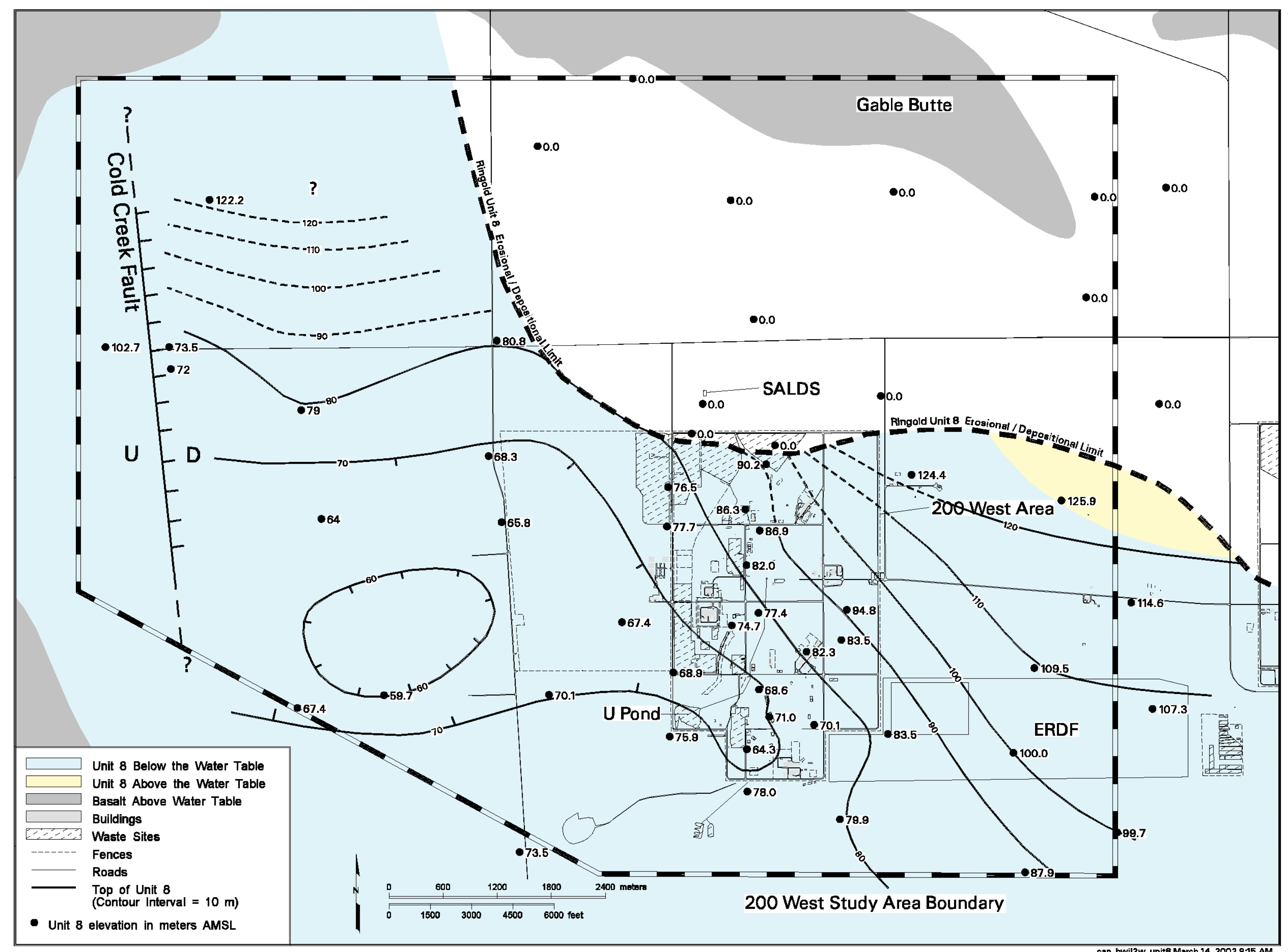

Plate 5. Top of Ringold Formation Unit 8 Structure Contour Map, 200-West Area and Vicinity 


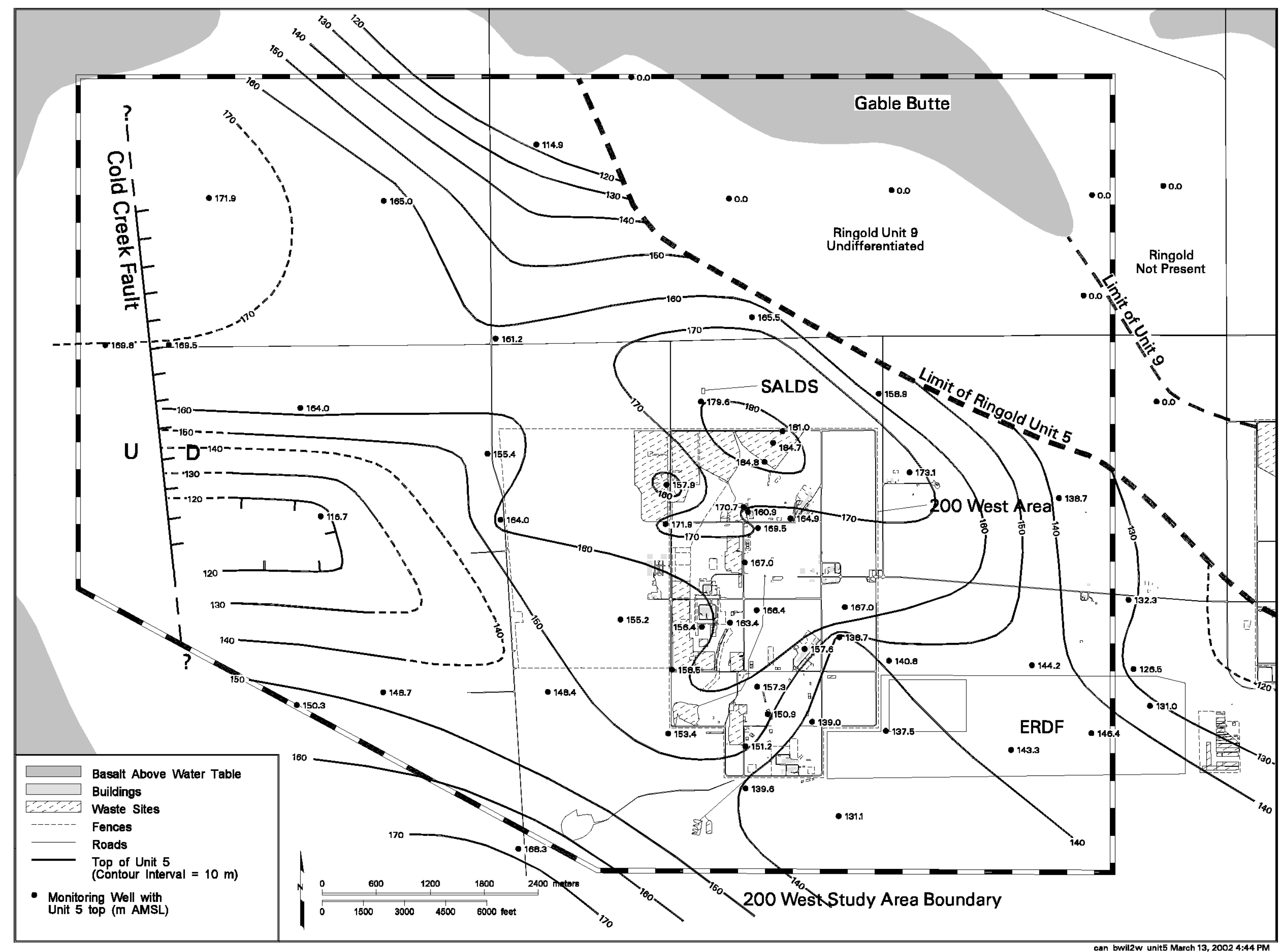

Plate 7. Ringold Formation Unit 5 Structure Contour Map, 200-West Area and Vicinity 


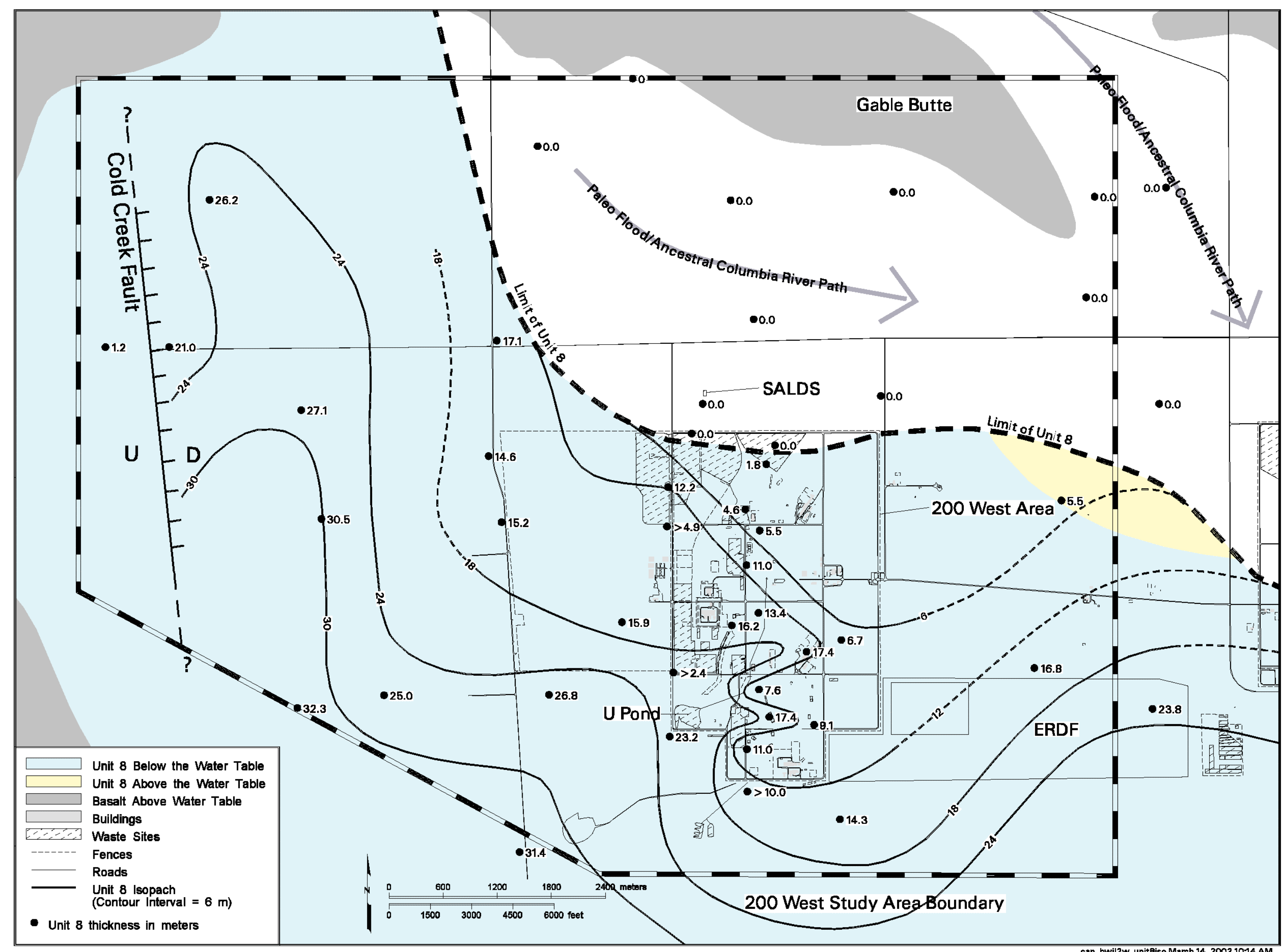

Plate 6. Ringold Formation Unit 8 Gross Interval Isopach Map, 200-West Area and Vicinity 


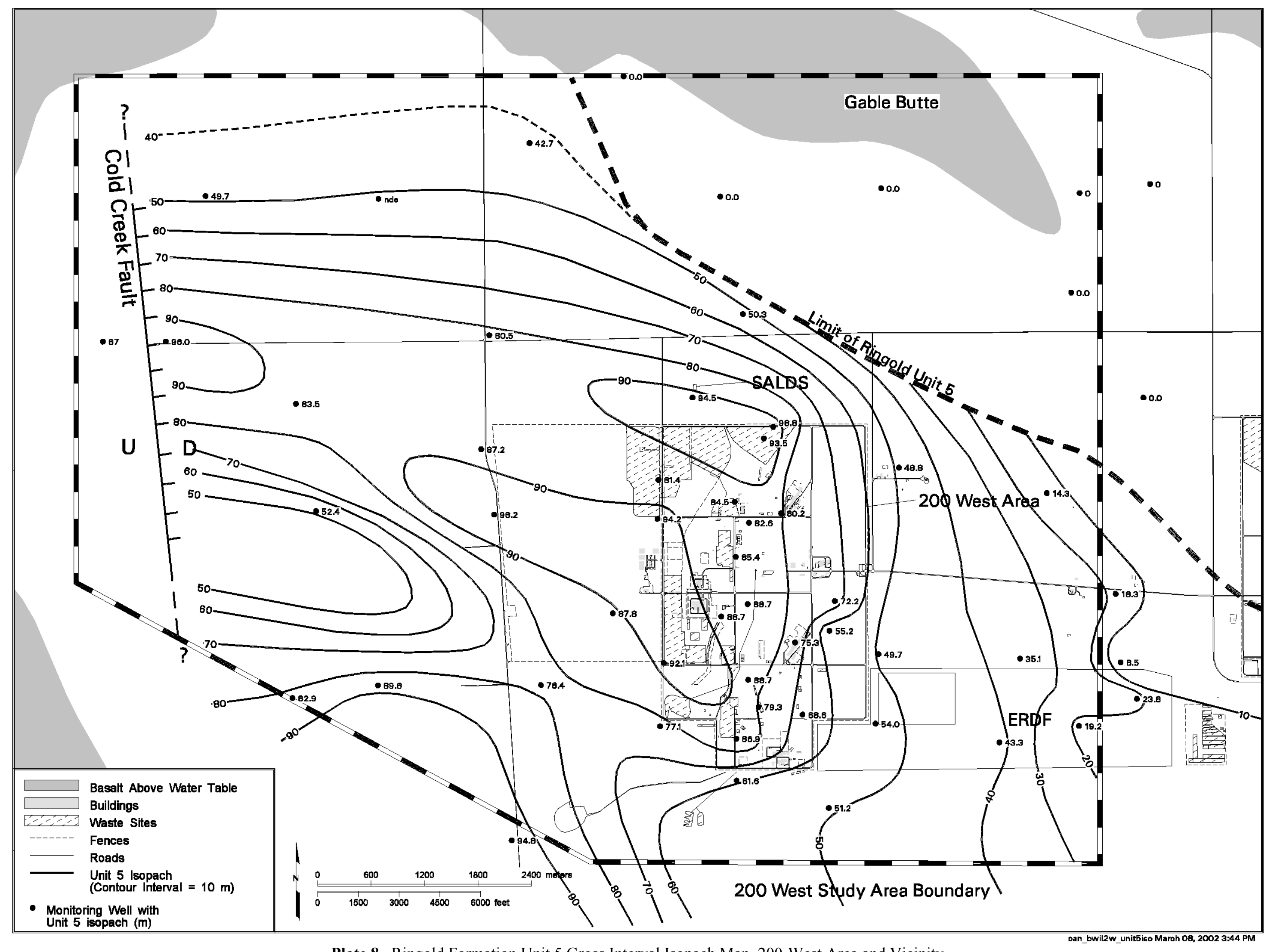

Plate 8. Ringold Formation Unit 5 Gross Interval Isopach Map, 200-West Area and Vicinity 

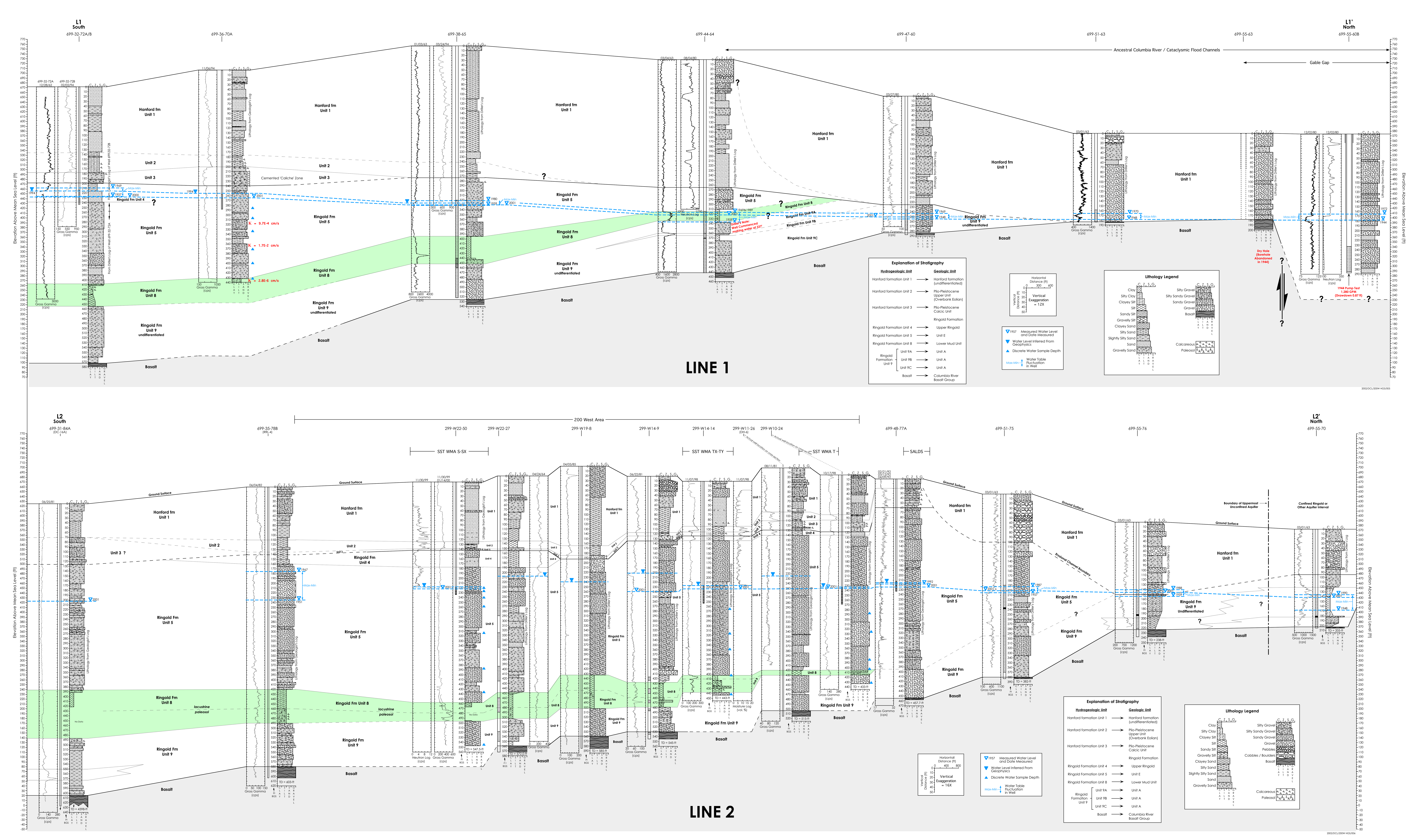

PLATE 9 


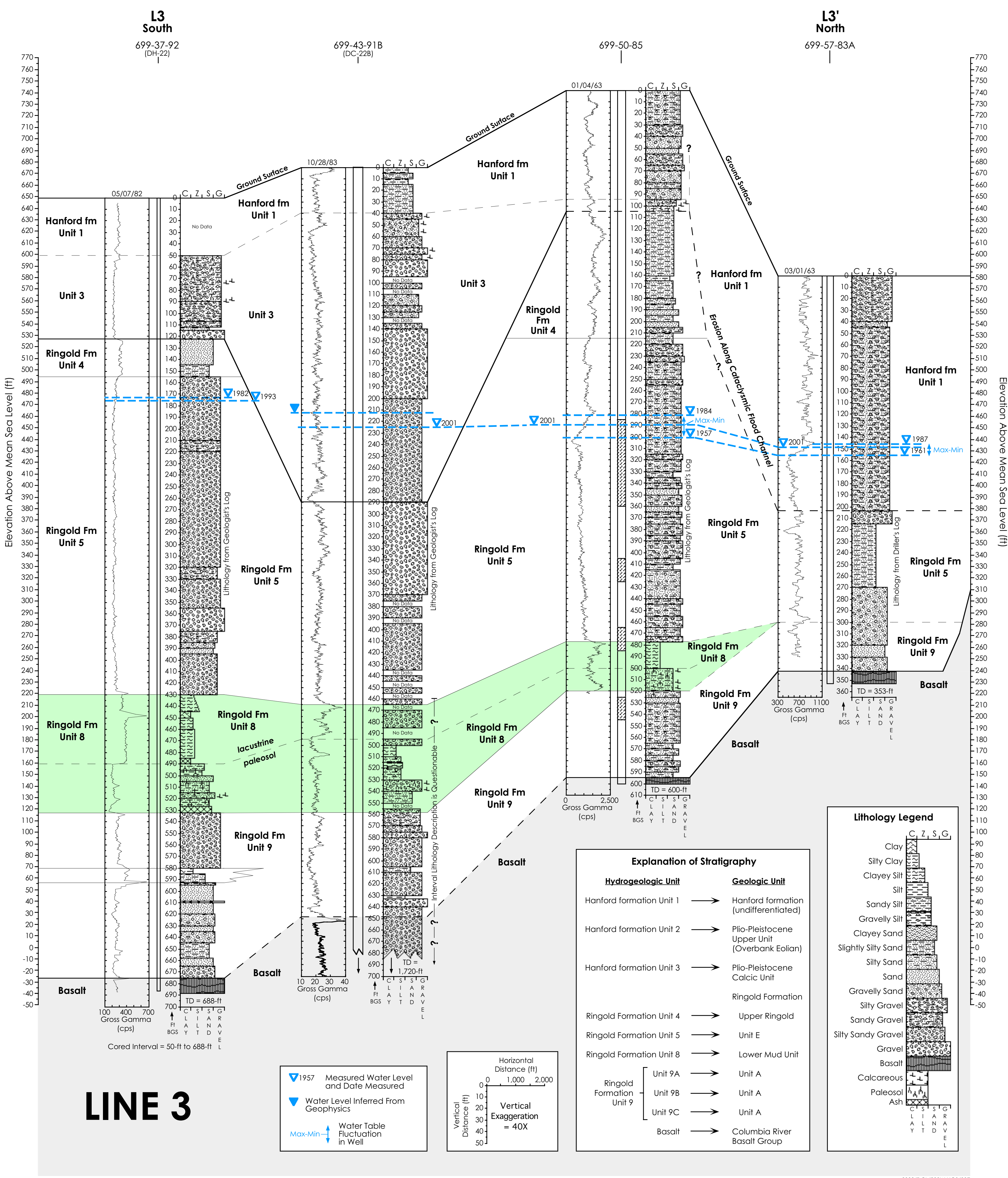




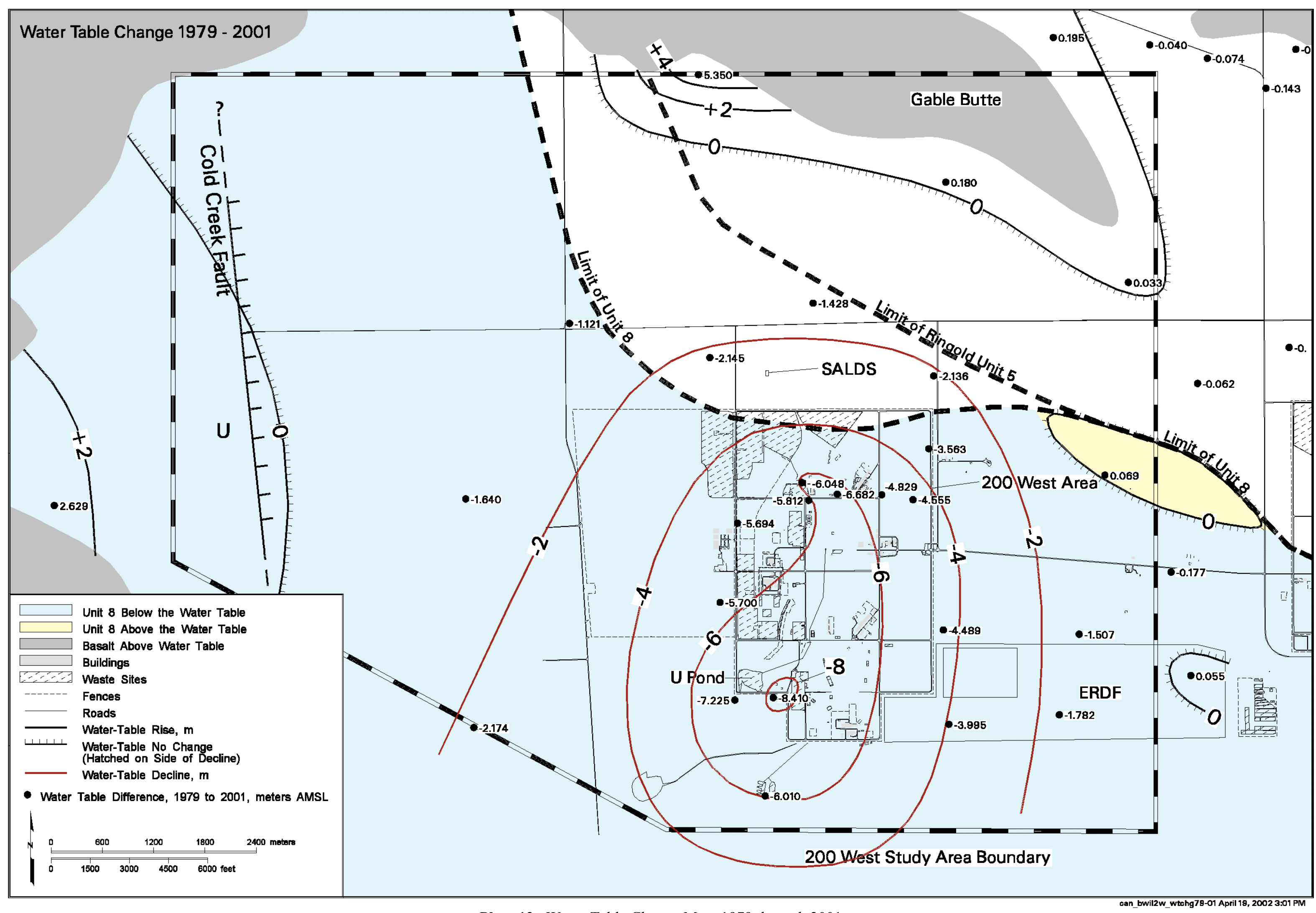

Plate 12. Water-Table Change Map, 1979 through 2001 


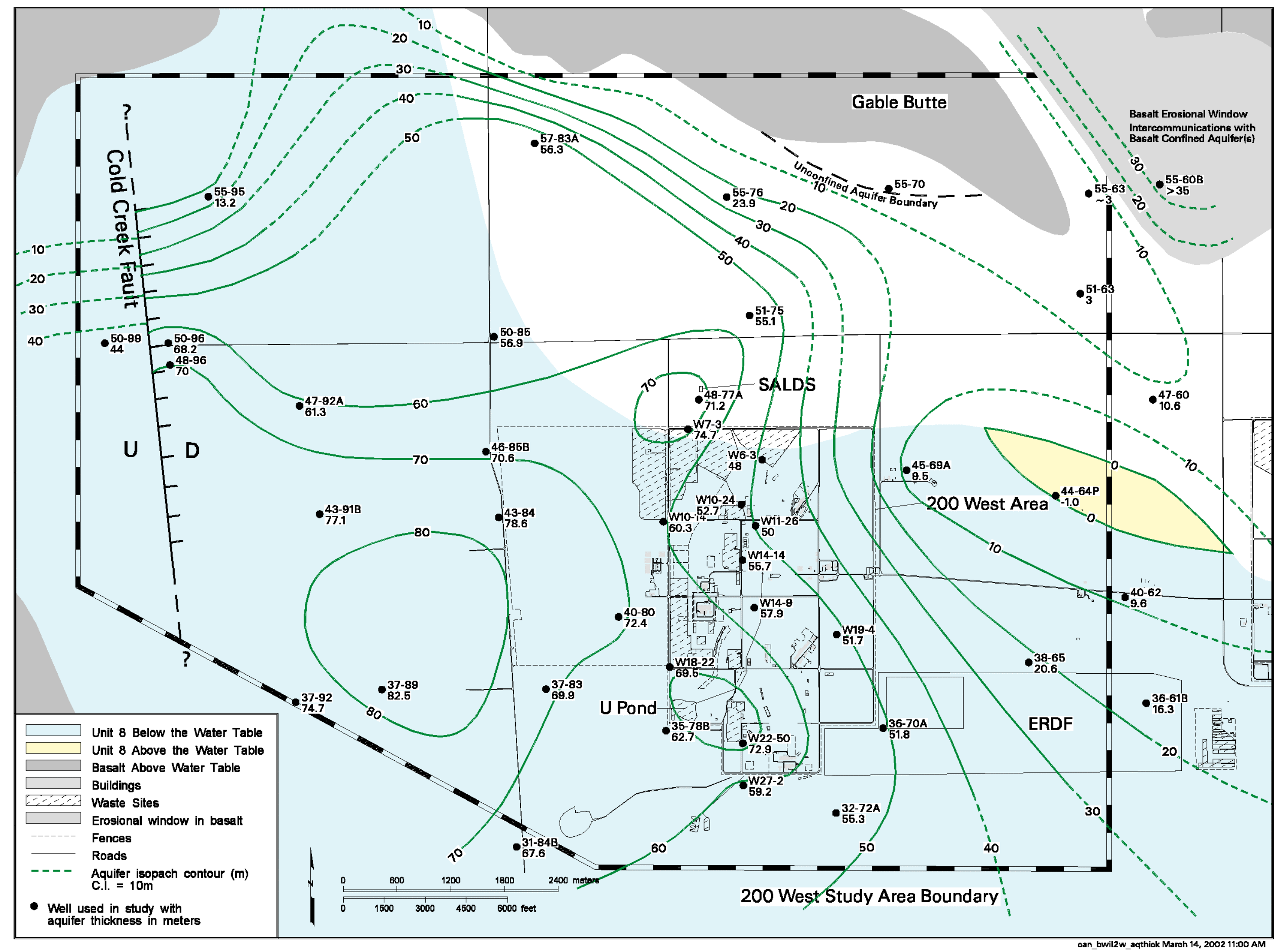

Plate 13. Uppermost-Unconfined Aquifer Thickness Map, 200-West Area and Vicinity 


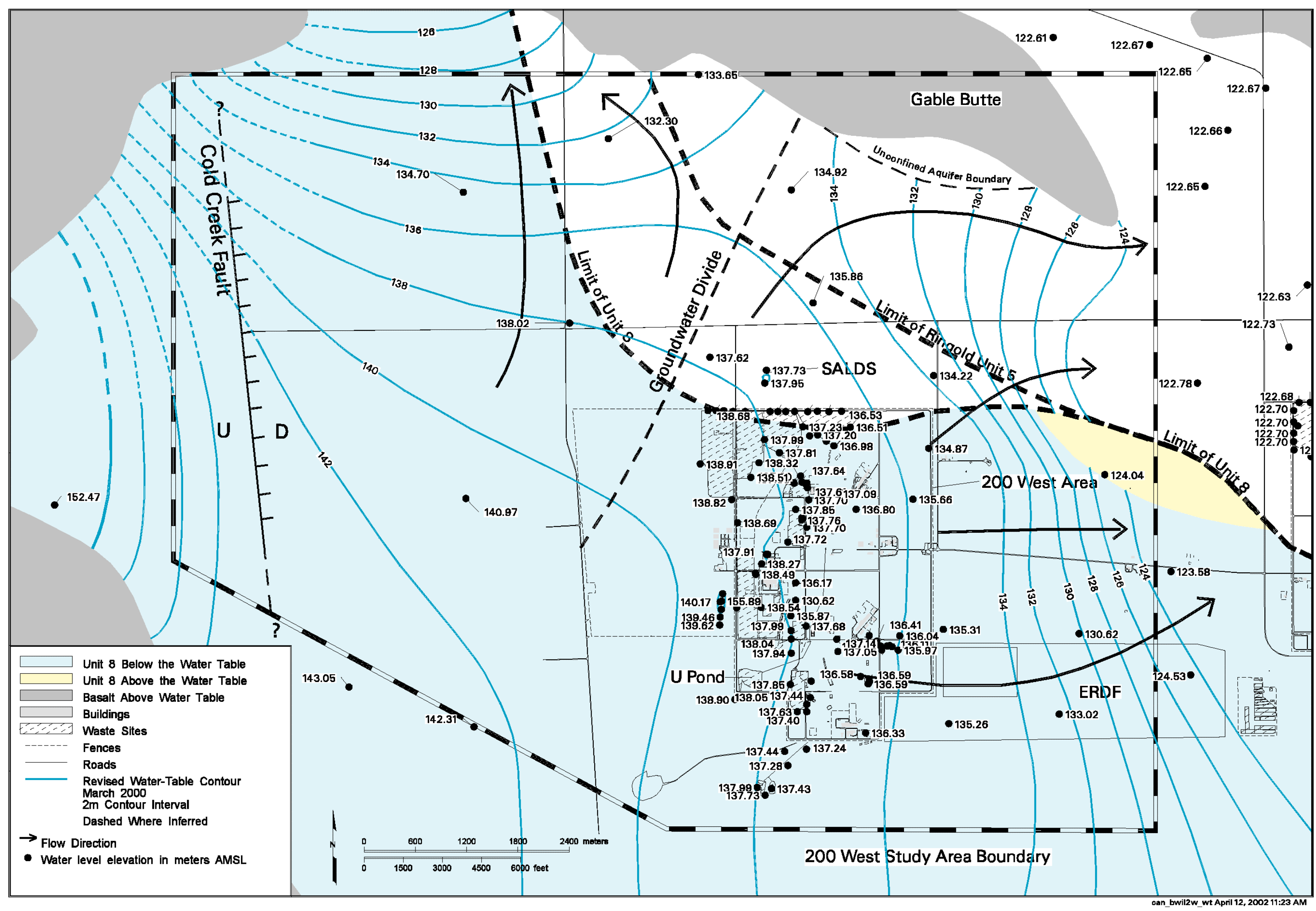

Plate 14. Revised Water-Table Map, Calendar Year 2000, 200-West Area and Vicinity 


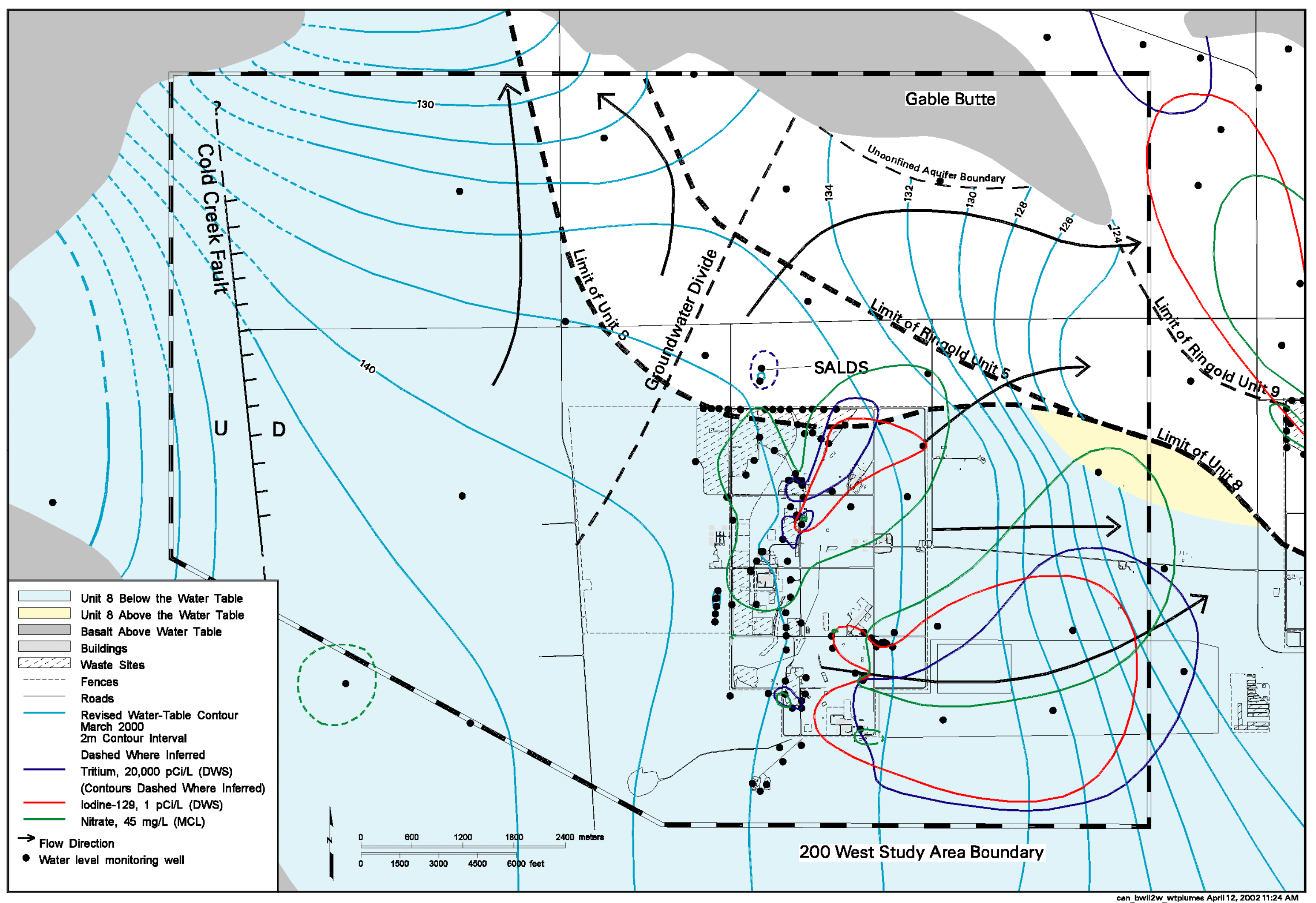

Plate 15. Composite Map Illustrating Several Regional Contaminant Plumes, 200-West Area and Vicinity 


\section{Distribution}

No. of

Copies

OFFSITE

2P M. Harmon

U.S. Department of Energy, EM-43

19901 Germantown Road

Germantown, MD 20874

CD K. D. Lindsey

Kennedy/Jenks Consultants

1020 North Center Parkway, Suite F

Kennewick, WA 99336

CD G. A. Smith

University of New Mexico

Department of Earth and Planetary Sciences 200 Yale Blvd. NE

Albuquerque, NM 87131

ONSITE

5 DOE Richland Operations Office

M. J. Furman (P)

R. D. Hildebrand (P)

J. G. Morse (P)

K. M. Thompson (P)

A. C. Tortoso (P)

4 Bechtel Hanford, Inc.

M. E. Byrnes (P)

K. R. Fecht (P)

B. H. Ford (P)
No. of

Copies

2 CH2M HILL Hanford, Inc.

L. C. Swanson (P)

H9-11

D. C. Weekes (CD)

H9-02

2 CH2M HILL Hanford Group, Inc.
A. J. Knepp (P)
$\mathrm{H} 0-22$
D. A. Myers (CD)
$\mathrm{H} 0-22$

Duratek Federal Services, Northwest

Operations

M. G. Gardner (P) H1-11

7 Fluor Hanford, Inc.

J. D. Davis $(\mathrm{P}) \quad \mathrm{H} 8-60$

J. D. Williams (CD) H8-20

J. C. Sonnichson (CD) N1-25

J. A. Winterhalder (CD) A1-14

M. I. Wood (P) H8-44

R. T. Wilde (P) H8-68

Marice Veatch $(\mathrm{P})$

(C/O M. L. Jackson) H8-68

A5-13

$\mathrm{H} 0-12$

$\mathrm{H} 0-12$

2 U.S. Environmental Protection Agency

D. R. Einan (P) B5-01

D. A. Faulk (P) B5-01

$\mathrm{H} 0-19$

$\mathrm{H} 0-19$

H0-19
4 Washington State Department of Ecology

J. Caggiano (P)

B5-18

D. Goswami (P)

B5-18

J. A. Hedges (P)

B5-18

A. D. Huckaby (P)

B5-18

Distr.1 
No. of

Copies

33 Pacific Northwest National Laboratory

D. B. Barnett (CD)

K6-81

M. P. Bergeron (CD)

B. N. Bjornstad (P)

R. W. Bryce (CD)

C. J. Chou (CD)

P. E. Dresel (CD)

M. D. Freshley (CD)

J. S. Fruchter $(\mathrm{P})$

M. J. Hartman (CD)

D. G. Horton (CD)

D. C. Lanigan (P)

G. V. Last (CD)

S. P. Luttrell (P)
No. of

Copies

J. P. McDonald (CD) K6-96

W. J. Martin (CD) K6-81

C. J. Murray K6-81

S. N. Narbutoskih (CD) K6-81

C. A. Newbill (CD) K6-96

S. P. Reidel (CD) K6-81

R. Schalla (CD) K6-96

R. M. Smith (P) K6-96

D. L. Stewart (CD) K6-96

F. A. Spane (CD) K6-96

M. D. Sweeney (CD) K6-96

P. D. Thorne (CD) K9-33

W. D. Webber (CD) K6-96

B. A. Williams (5P) K9-36

Hanford Technical Library (2P) P8-55 